GUILHERME TILKIAN

\title{
O PRINCÍPIO DA CONFIANÇA LEGÍTIMA SOB A PERSPECTIVA DAS PRÁTICAS REITERADAMENTE OBSERVADAS PELAS AUTORIDADES ADMINISTRATIVAS EM MATÉRIA TRIBUTÁRIA
}

DISSERTAÇÃO DE MESTRADO EM DIREITO ECONÔMICO-FINANCEIRO

UNIVERSIDADE DE SÃO PAULO

Faculdade de Direito

São Paulo, 2014 
GUILHERME TILKIAN

\title{
O PRINCÍPIO DA CONFIANÇA LEGÍTIMA SOB A PERSPECTIVA DAS PRÁTICAS REITERADAMENTE OBSERVADAS PELAS AUTORIDADES ADMINISTRATIVAS EM MATÉRIA TRIBUTÁRIA
}

\begin{abstract}
Dissertação apresentada, à Comissão Julgadora da Faculdade de Direito da Universidade de São Paulo, como exigência parcial para a obtenção do título de Mestre e m Direito Econômico-Financeiro, subárea Direito Tributário, sob a orientação do Professor Doutor Roberto Quiroga Mosquera.
\end{abstract}

UNIVERSIDADE DE S ÃO PAULO

Faculdade de Direito

São Paulo, 2014 
BANCA EXAMINADORA

Orientador: Professor Doutor Roberto Quiroga Mosquera 
Aos meus pais, Paulo e Stela.

À Bia, minha esposa. 


\section{RESUMO}

Este trabalho versa sobre a aplicação do princípio da confiança legítima no Direito Tributário brasileiro, com foco no art. 100, inciso III, do Código Tributário Nacional (CTN), que trata das práticas reiteradamente observadas pelas autoridades administrativas. Parte-se da origem do princípio, aproximando a investigação por meio do princípio da segurança jurídica, da certeza do direito e da irretroatividade; em seguida, diferencia-se a proteção da confiança da boa-fé objetiva e prossegue-se pelo princípio da legalidade e a evolução jurisprudencial a respeito da conservação - positiva ou negativa - dos atos eivados de vícios quando deles se originaram direitos. Foca-se, então, nos requisitos para a configuração da confiança digna de proteção e os mecanismos de proteção positiva ou negativa dessa confiança. Desse ponto em diante, o estudo passa a desenhar a proteção da confiança legítima nos atos do Poder Executivo, por meio da análise do art. 100 do CTN, como fonte secundária de direito tributário. Conceituam-se as normas complementares, a origem e sua função, para então proceder-se ao exame específico das práticas reiteradamente observadas pelas autoridades administrativas e sua relação com o princípio da confiança legítima. Em seguida, analisa-se o parágrafo único do art. 100 do CTN para avaliar se são corretas a não atualização monetária da base de cálculo do tributo e a admissão de retroatividade parcial dos efeitos do reconhecimento da ilegalidade da prática administrativa em que confiou o contribuinte. Examina-se, de início, se a inércia da Administração Pública acerca de lançamento cuja homologação se dê de maneira tácita seria um silêncio positivo a configurar prática reiterada suficiente para dar respaldo à proteção do parágrafo único do art. 100 do CTN. O estudo avalia se, no caso dos tributos indiretos, pela impossibilidade de o contribuinte transferir ao consumidor a exação, justificaria uma proteção maior do que aquela conferida pelo próprio parágrafo único do art. 100 do CTN. Por derradeiro, a norma do art. 146 é confrontada com a do art. 100, inciso III, ambos do CTN, para fins de estabelecer os campos de aplicação de uma e de outra e em que medida elas se relacionam com a proteção da confiança legítima.

Palav ras-chave: Direito Tributário. Princípio da confiança legítima. Aplicação. Práticas Reiteradamente Observadas pelas Autoridades Administrativas. 


\begin{abstract}
This work deals with the application of the principle of legitimate expectations in Brazilian tax law, focusing on Article 100, section III of the Brazilian Tax Code, which deals with the practices observed repeatedly by administrative authorities. The proposed scientific part of the origin of the principle, approaching research through the principle of legal security, legal certainty and non-retroactivity. Then differentiates the protection of reliable objective good faith and goes by the principle of legality and judicial developments regarding conservation (positive or negative) of the acts riddled with addictions when their rights originated. Focuses, then, on the requirements for setting up trust worthy of protection and the protection mechanisms positive or negative that trust. Thereafter the study is to draw back the protection of legitimate expectations in the acts of the Executive, through the analysis of Article 100 of the Internal Revenue Code, as secondary sources of tax law. Conceptualize themselves supplementary rules, the origin and function, down to the specific scope of practice repeatedly observed by the administrative authorities and their relation to the principle of legitimate expectations. Then we analyze the sole paragraph of article 100 of the Internal Revenue Code to assess whether it is correct not to monetary base tax calculation and admission of retroactivity of the effects of partial recognition of the illegality of administrative practice that relied on the taxpayer. Turning to specific issues initially analyzed is the inertia of public administration, which tacitly approves taxes charged for approval, would be a positive silence configuring repeated practice enough to give birth to protect the sole paragraph of article 100 of the Tax Code national. The study evaluates whether, in the case of indirect taxes, the inability of the taxpayer to transfer the consumer the exaction would justify greater protection than that afforded by the sole paragraph of article 100 of the Internal Revenue Code. Finally, the norm of Article 146 is confronted with Article 100, item III, both of the National Tax Code, for purposes of establishing fields of application of one and the other and the extent to which both relate to the protection of legitimate expectations.
\end{abstract}

Key Words: Tax Law. Principle of legitimate expectations. Application. Repeatedly Practices Observed by Administrative Authorities. 


\section{SUMÁRIO}

INTRODUÇÃO ................................................................................................................ 10

CAPÍTULO 1 - TEORIA DOS PRINCÍPIOS .............................................................. 12

1.1 Teoria Clássica ........................................................................................................ 12

1.2 Teoria Moderna .................................................................................................. 13

1.2.1 A Doutrina de Ronald D workin ................................................................................. 15

1.2.2 A Doutrina de Robert Alexy .......................................................................................... 16

1.2.3 A Doutrina de Humbe rto Bergmann Ávila ............................................................. 18

1.2.3.1 Crítica à Teoria Clássica ............................................................................................. 18

1.2.3.2 Crítica à Teoria de Ronald Dworkin e Robert Alexy ............................................ 21

1.2.3.3 Proposta de Distinção entre Regras e Princípios ................................................... 22

1.2.3.3.1 Distinção entre Regras e Princípios - Definição de Postulados ...................... 23

1.2.3.4 Prevalência das Regras sobre Princípios ................................................................ 25

1.2.3.5 Procedime nto de Superabilidade das Regras ......................................................... 26

1.2.3.5.1 Requisitos Materiais .............................................................................................. 27

1.2.3.5.2 Requisitos Procedimentais ................................................................................ 29

1.3 Os Princípios da Constituição Federal de 1988 ............................................................ 30

CAPÍTULO 2 - PRINCÍPIO DA CONFIANÇA LEGÍTIMA E BOA-FÉ .................... 33

CAPÍTULO 3 - CER TEZA DO DIREITO E CONFIANÇA LEGÍTIMA ................... 43

CAPÍTULO 4 - PRINCÍPIO DA CONFIANÇA LEGÍTIMA ........................................... 48

4.1 Da Irretroatividade como Mecanismo Justificador do Princípio da

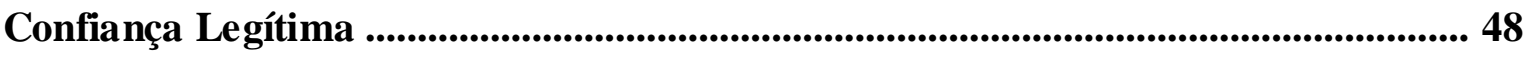

4.1.1 O Sistema de Luhmann .............................................................................................. 48

4.1.1.1 O Papel da Confiança na Formação do Sistema .................................................... 49

4.1.1.2 Da Simplicidade da Confiança Familiar à Evolução para a

Confiança Sistêmica ................................................................................................................... 51 
4.1.1.3 Da Confiança à Desconfiança ..................................................................... 55

4.1.1.4 A Solução de Conflitos no Interior do Sistema ................................................ 58

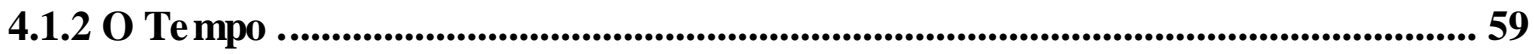

4.1.3 O Princípio da Confiança Legítima e o Tempo do Poder Executivo .................. 62

4.2 Os Primeiros Estudos do Princípio da Confiança no Brasil ................................. 66

4.2.1 A Origem do Princípio da Confiança Legítima e a Evolução do Princípio

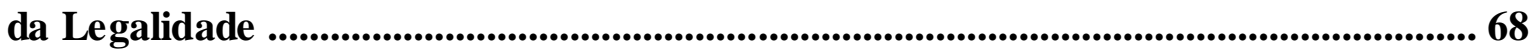

4.2.2 A Evolução do Princípio da Legalidade no B rasil .................................................. 73

CAPÍTULO 5 - REQUISITOS PARA APLICAÇÃO DO PRINCÍPIO DA

CONFIANÇA E ESPÉCIES DE PROTEÇÃO ........................................................ 85

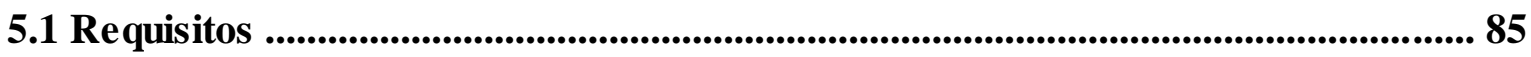

5.1.1 Crité rio do Grau de Vinculação da Base (Base Vinculante - Base

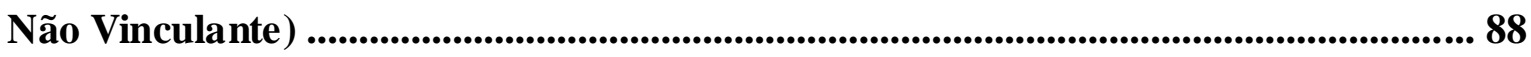

5.1.2 Crité rio do Grau de Aparência de Legitimidade da Base

(Base Válida-Base Inválida)

5.1.3 Crité rio do Grau de Modificabilidade da Base (Base com Alta Pretensão

de Permanência-Base com Baixa Pretensão de Permanência)

5.1.4 Crité rio do Grau de Eficácia no Tempo da Base (Eficácia

Curta-Eficácia Duradoura)

5.1.5 Crité rio do Grau de Realização das Finalidades da Base (Base Efetiva-Base

Não Efetividade) ....................................................................................................................... 92

5.1.6 Crité rio do Grau de Indução da Base (Base Indutora-Base Neutra) .................. 93

5.1.7 Crité rio do Grau de Individualidade da Base (Base Individual-Base Geral) ... 93

5.1.8 Crité rio do Grau de Onerosidade da Base (Base Onerosa-Base Gratuita) ....... 94

5.2 Espécies de Proteção ................................................................................................................... 97

CAPÍTULO 6 - PROTEÇÃO DA CONFIANÇA LEGÍTIMA NA A TUAÇÃO DO

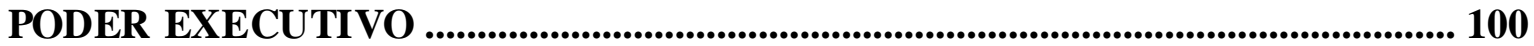

6.1 Atuação Administrativa Abstrata e Geral - Atos Normativos ............................. 101

6.2 Atuação Administrativa Individual e Concreta - Atos Administrativos ............. 104

6.3 Prática Administrativa ................................................................................................. 105 
CAPÍTUlO 7 - APLICAÇÃO DO ARTIGO 100 DO CÓdigo TRIBUTÁRIO NACIONAL E PRINCÍPIO DA CONFIANÇA LEGÍTIMA ........................................ 107

7.1 Artigo 100, Inciso III, do Código Tributário Nacional - Práticas

Administrativas 108

7.2 Autoridades Administrativas

7.3 Práticas Reiteradamente Observadas pelas Autoridades Administrativas e o Princípio da Confiança Legítima

7.4 Práticas Reiteradamente Observadas pelas Autoridades Administrativas

e a Supressio Tributária

7.5 Da Inércia como Configuradora das Práticas Administrativas - Tributos

Sujeitos a Lançamento por Homologação

7.6 Do Parágrafo Único do Artigo 100 do Código Tributário Nacional -

Correção Monetária

7.7 Da Aplicação do Artigo 100, Inciso III, e Respectivo Parágrafo Único do

Código Tributário Nacional aos Impostos Indiretos 135

7.8 Campos de Aplicação dos Artigos 146 e 100 do Código Tributário Nacional .... 139

CONCLUSÃO 146

REFERÊNCIAS 153 


\section{INTRODUÇÃO}

Após mais de vinte anos de ditadura, o Brasil pôde, com a instalação da Assembleia Nacional Constituinte, aspirar a novos rumos que o conduziram ao Estado Democrático de Direito com a promulgação da Constituição Federal (CF) de 1998, designada por Ulisses Guimarães Constituição Cidadã. Iniciaram-se, a partir daí, inúmeras transformações, deixando para trás as mazelas advindas do golpe militar de 31 de março de 1964 como, por exemplo, os famigerados Atos Institucionais. Foram alcançadas conquistas de expressão, como poder limitado, dignidade da pessoa humana, direitos fundamentais, justiça social, tolerância, entre outros ${ }^{1}$. Reconhece-se, no entanto, que existe um longo percurso a caminhar para o fortalecimento das instituições do Estado de Direito.

A experiência jurídica dos últimos anos tem demons trado que, em certos ramos do direito, notadamente no Direito Tributário, o Estado ainda está longe de proporcionar a segurança jurídica em sua relação com os contribuintes, apregoada pelo art. 5으 da Constituição Federal.

Essa insegurança se manifesta de diversas formas, revelando-se por meio: (a) da incerteza do direito aplicável; (b) da mudança abrupta de posições jurídicas consolidadas; (c) da instabilidade das relações jurídicas; (d) do desrespeito à Constituição Federal no mero intuito arrecadatório, pautado no desconhecimento e na falta de assessoria jurídica para defesa dos interesses da maioria dos contribuintes; (e) da utilização do "princípio" do "caixa do governo" como instrumento de pressão política ao Supremo Tribunal Federal (STF), entre outros.

O presente trabalho se propõe a analisar o princípio da confiança legítima da perspectiva das práticas reiteradamente observadas pelas autoridades administrativas em matéria tributária.

No Capítulo 1, aborda-se a teoria dos princípios, que passa pela análise da Teoria Clássica e da Teoria Moderna e, por fim, apresentam-se as definições de regras, princípios e postulados pelas quais Humberto Ávila constrói sua teoria.

\footnotetext{
1 BARROSO, Luís Roberto. Vinte anos da Constituição de 1988: a reconstrução democrática do Brasil. Revista Justitia, São Paulo, v. 198, p. 255-267, jan./jun. 2008.
} 
No Capítulo 2, traçam-se os pontos que identificam e que estremam a boa-fé objetiva e o princípio da confiança legítima.

Em seguida, no Capítulo 3, faz-se uma breve exposição sobre o princípio da segurança jurídica e da certeza do direito com o propósito de buscar o fundamento do princípio da confiança por dedução do princípio da irretroatividade.

Prossegue-se, no Capítulo 4, com o panorama dos primeiros estudos do princípio da confiança legítima no Brasil, para então avaliar a evolução do princípio da legalidade e a superação, na esfera do direito público, de que o nulo não sana, ou seja, não convalesce.

No Capítulo 5, passa-se a investigar os requisitos para aplicação do princípio da confiança legítima e as consequências derivadas de sua aplicação, quais sejam, a proteção positiva, com a manutenção do ato ilegal no mundo jurídico, ou a proteção negativa, isto é, o ressarcimento dos danos experimentados por aquele que confiou.

No Capítulo 6, examina-se a aplicação do princípio da confiança legítima nos atos do Poder Executivo e delineia-se o panorama das normas gerais no Direito Tributário.

Em seguida, no Capítulo 7, analisa-se a aplicação do art. 100, inciso III, do CTN e sua relação com o princípio da confiança legítima. Prossegue-se, então, com a confrontação da supressio do direito privado, com as práticas reiteradamente observadas pelas autoridades administrativas em matéria tributária e as consequências previstas no parágrafo único do art. 100 do CTN.

Ainda nesse capítulo, examina-se o inciso III do referido artigo, da perspectiva do lançamento cuja homologação se dê de maneira tácita e se essa circunstância autorizaria a aplicação dos efeitos do parágrafo único do mencionado dispositivo. Analisa-se, também, a repercussão econômica dos impostos indiretos e a justiça da aplicação do parágrafo único do art. 100 do CTN.

Por derradeiro, confronta-se a aplicação dos arts. 100, inciso III, e 146, ambos do CTN, a fim de avaliar situações de aplicação de um e de outro e como eles albergam o princípio da confiança legítima.

Ao final do trabalho são apontadas as conclusões alcançadas por meio da presente dissertação. 


\section{CAPÍTULO 1}

\section{TEORIA DOS PRINCÍPIOS}

A teoria dos princípios está atualmente dividida entre aquilo que se convencionou chamar de Teoria Clássica e a Teoria Moderna. Naquela, encontra-se como seu principal expoente o professor Celso Antônio Bandeira de Mello. A Teoria Moderna, por sua vez, é capitaneada pelos professores Ronald Dworkin e Robert Alexy e, com os devidos aprimoramentos, pelo professor Humberto Bergmann Ávila.

\subsection{Teoria Clássica}

De acordo com a Teoria Clássica, defendida por Celso Antônio Bandeira de Mello, princípio seria, por definição, mandamento nuclear de um sistema, verdadeiro alicerce dele, disposição fundamental que se irradia sobre diferentes normas, compondo-lhes a tônica que lhe dá sentido harmônico. Daí por que

“[...] violar um princípio é muito mais grave que transgredir uma norma. A desatenção ao princípio implica ofensa não apenas a um específico mandamento obrigatório, mas a todo o sistema de comandos. E a mais grave forma de ilegalidade ou inconstitucionalidade, conforme o escalão do princípio violado, porque representa insurgência contra todo o sistema, subversão de seus valores fundamentais, contumélia irremissível a seu arcabouço lógico e corrosão de sua estrutura mestra"².

Com esteio em Celso Antônio Bandeira de Mello e Geraldo Ataliba e filiando-se igualmente à Teoria Clássica, Roque Antonio Carrazza também explica que o sistema jurídico se ergue como um vasto edifício, onde tudo está disposto em sábia arquitetura. Ao

\footnotetext{
2 BANDEIRA DE MELlo, Celso Antônio. Curso de direito administrativo. São Paulo: Malheiros, 2009. p. 53.
} 
contemplá-lo, o jurista não só encontra a ordem, na aparente complicação, como identifica, imediatamente, alicerces e vigas mestras. Diz o autor:

\begin{abstract}
"Ora, num edifício tem importância: as portas, as janelas, as luminárias, as paredes, os alicerces etc. No entanto, não é preciso termos conhecimentos aprofundados de Engenharia para sabermos que muito mais importantes que as portas, as janelas (facilmente substituíveis) são os alicerces e as vigas mestras [trata-se da função dos princípios no ordenamento jurídico]. Tanto que, se de um edifício retirarmos ou destruirmos uma porta, uma janela ou até mesmo uma parede, ele não sofrerá nenhum abalo mais sério em sua estrutura, podendo ser reparado (ou até embelezado). Já, se dele subtrairmos os alicerces, fatalmente cairá por terra" ${ }^{3}$.
\end{abstract}

Para essa corrente doutrinária, portanto,

“[...] princípio jurídico é um enunciado lógico, implícito ou explícito, que, por sua grande generalidade, ocupa posição de preeminência nos vastos quadrantes do Direito e, por isso mesmo vincula, de modo inexorável, o entendimento e a aplicação das normas jurídicas que com ele se conectam",

Dessas considerações, revela-se que a caracterização do princípio pela doutrina clássica se dá em face do alto grau de generalidade e abstração da norma, bem como da prevalência dos princípios sobre as demais normas, de sorte que a violação a um princípio abalaria todo o ordenamento jurídico.

\title{
1.2 Teoria Mode rna
}

O rompimento com essa Teoria Clássica, que enxergava na "generalidade" e "abstração" as características pertinentes aos princípios, fez surgir a Teoria Moderna que propôs uma classificação tida como forte, trazendo outros elementos para distinção das

\footnotetext{
${ }^{3}$ CARRAZZA, Roque Antonio. Curso de direito constitucional tributário. 20. ed. São Paulo: Malheiros, 2004. p. 35.

${ }^{4}$ Ibidem, loc. cit..
} 
regras e dos princípios ${ }^{5}$. Os principais expoentes dessa nova doutrina foram os juristas Ronald Dworkin e Robert Alexy.

Para essa segunda corrente doutrinária, em síntese, os princípios são normas que se caracterizam por serem aplicadas mediante ponderação com outras e por poderem ser realizadas em vários graus, contrariamente às regras, que estabelecem em sua hipótese definitivamente aquilo que é obrigatório, permitido ou defeso, e que, por isso, exigem uma aplicação mediante subsunção.

Dessa concepção origina-se a afirmação de que os princípios são diferentes das regras relativamente ao modo de aplicação e ao modo como são solucionadas as antinomias que surgem entre eles ${ }^{6}$.

A diferença no tocante ao modo de aplicação é a seguinte: as regras estabelecem mandamentos definitivos e são aplicadas mediante subsunção, já que o aplicador deverá confrontar o conceito do fato com o conceito constante da hipótese normativa e, havendo encaixe, aplicar a consequência, ao passo que os princípios estabelecem deveres provisórios e são aplicados mediante ponderação, na medida em que o aplicador deverá atribuir uma dimensão de peso aos princípios diante do caso concreto.

A diferença no que toca ao modo de solução das antinomias, então, é: o conflito entre regras ocorre no plano abstrato, é necessário e implica declaração de invalidade de uma delas caso não seja aberta uma exceção, ao passo que o conflito de princípios ocorre apenas no plano concreto, é contingente e não implica declaração de invalidade de um

\footnotetext{
${ }^{5}$ Em nota de rodapé de seu livro, Celso Antônio Bandeira de Mello rebate as críticas da Teoria Moderna, de Dworkin e Alexy, afirmando que a teoria por ele defendida pauta-se em uma das possíveis acepções da palavra "princípio". Trata-se da mais tradicional delas, ou seja, aquela que vem sendo adotada ao longo dos tempos pela doutrina. Sem embargo, como ninguém é dono das palavras, pode-se atribuir este mesmo rótulo a outros mentáveis. Genaro Carrió arrola onze significados para tal expressão (CARRIÓ Genaro. Princípios jurídicos y positivismo jurídico. Buenos Aires: Abeledo-Perrot, 1970. p. 34-38). A partir da década de 1970 começou a vulgarizar-se uma acepção de princípio pautada nas formulações de Alexy e Dworkin - que de resto não são idênticas, mas têm grandes pontos de similitude. Ocorre que estes eminentes juristas não expropriaram - até mesmo em razão da impossibilidade - o direito ao uso de tal expressão, de modo a tornar admissível apenas a acepção que lhe emprestam. Então, é possível que algo seja qualificado como princípio, de acordo com uma dada acepção de princípio, descoincidente com a que the irrogam os referidos autores. É óbvio, pois, que seria erro bastante grave pretender avaliar o objeto dessarte identificado como prin cíp io, para atribuir-lhe características distintas das que lhe foram irrogadas por quem dele se serviu, valendo-se de critério que estivesse assentado em outra acepção de princípio, qual a que lhe conferem Alexy e Dworkin. Is so implicaria falar de "A" supondo referir-se a "B". Quem cometer tal erro em obra teórica - e isso tem ocorrido ultimamente - estará incorrendo em séria impropriedade, induzindo terceiros incautos a incidirem no mesmo deplorável equívoco (BANDEIRA DE MELLO, Celso Antônio. Curso de direito administrativo, 2009, p. 34).

${ }^{6}$ Á VILA, Hu mberto Berg mann. Teoria dos princípios. 11. ed. São Paulo: Malheiros, 2010. p. 87.
} 
deles, mas o estabelecimento de uma regra de prevalência de determinadas circunstâncias verificáveis somente no plano da eficácia das normas.

O fundamento dessa distinção está na estrutura normativa: os princípios, porque instituem mandamentos superáveis no confronto com outros princípios, permitem o sopesamento, ao passo que as regras, porque estabelecem deveres pretensamente definitivos, eliminam ou diminuem sobremaneira a liberdade apreciativa do aplicador. Trata-se, assim, de uma distinção forte: os princípios e as regras não têm as mesmas propriedades, mas qualidades diferentes; as regras instituem deveres definitivos (deveres que não podem ser superados por razões contrárias) e são aplicadas por meio da subsunção (exame de correspondência entre o conceito normativo e o conceito material fático), ao passo que os princípios es tabelecem deveres provisórios (deveres que podem ser superados por razões contrárias) e são aplicados mediante ponderação (sopesamento concreto entre razões colidentes, com atribuição de peso maior a uma delas); o conflito entre regras é abstrato (abstratamente concebível já no plano abstrato) e situado no plano da validade (o conflito resolve-se com a decretação de invalidade de uma das regras envolvidas), ao passo que a antinomia entre princípios é concreta (só ocorre diante de determinadas circunstâncias concretas), contingente (pode ou não ocorrer) e situada no plano da eficácia (ambos os princípios mantêm a validade após o conflito).

\subsubsection{A Doutrina de Ronald Dworkin}

Consoante exposto, a doutrina moderna iniciou-se com os estudos de Ronald Dworkin, cuja finalidade ${ }^{7}$ consistiu em proceder a um ataque geral ao Positivismo, sobretudo no que se refere ao modo aberto de argumentação permitido pela aplicação do

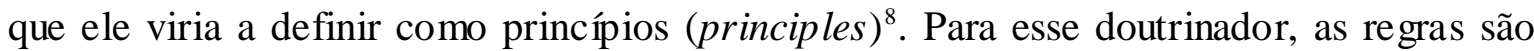
aplicadas ao modo tudo ou nada (all-or-nothing), no sentido de que, se a hipótese de incidência de uma regra é preenchida, ou é a regra válida e a consequência normativa deve ser aceita, ou ela não é considerada válida. No caso de colisão entre regras, uma delas deve

\footnotetext{
${ }^{7}$ Á VILA, Hu mberto Berg mann. Teoria dos princípios, p. 37.

${ }^{8}$ DWORKIN, Ronald. The model of rules. University of Chicago Law Review 35/14; e Is a law a system of rules? In: DWORKIN, R. M. (Ed.). The philosophy of law. Oxford: Oxford University Press, 1977. p. 43.
} 
ser considerada inválida. Os princípios, ao contrário, não determinam absolutamente a decisão, mas somente contêm fundamentos, os quais devem ser conjugados com outros fundamentos provenientes de outros princípios ${ }^{9}$.

Daí a afirmação de que os princípios, ao contrário das regras, possuem uma dimensão de peso (dimension of weight), demonstrável na hipótese de colisão entre os princípios, caso em que o princípio com peso relativo maior se sobrepõe ao outro, sem que este perca sua validade ${ }^{10}$.

\subsubsection{A Doutrina de Robert Alexy}

Na trilha do caminho inicialmente percorrido por Ronald Dworkin, Robert Alexy avançou ainda mais seus estudos acerca do conceito de princípios. Para Alexy, os princípios jurídicos consistem apenas em uma espécie de normas jurídicas por meio da qual são estabelecidos deveres de otimização aplicáveis em vários graus, segundos as possibilidades normativas e fáticas ${ }^{11}$. Com base na jurisprudência do Tribunal Constitucional Alemão, esse doutrinador procurou demonstrar a relação de tensão ocorrente no caso de colisão entre os princípios: nesse caso, a solução não se resolve com a determinação imediata da prevalência de um princípio sobre o outro, mas é estabelecida em face da ponderação entre os princípios colidentes, em função da qual um deles, em determinadas circunstâncias concretas, recebe a prevalência ${ }^{12}$.

Os princípios, portanto, possuem apenas uma dimensão de peso e não determinam as consequências normativas de forma direta, ao contrário das regras ${ }^{13}$. É só a aplicação dos princípios diante dos casos concretos que os concretiza mediante regras de colisão. Por

\footnotetext{
${ }^{9}$ DWORKIN, Ronald. Taking rights seriously. 6. tir. London: Duckworth, 1991. p. 26; e Is law a system of rules?, The philosophy of law, p. 45.

${ }^{10}$ Idem. Taking rights seriously, p. 26.

11 ALEXY, Robert. Zum Begriff des Rechtsprinzips. Argumentation und Hermeneutik in der Jurisprudenz, Rechtstheorie. Separata 1. Berlin, Dunckler und Humblot, 1979. p. 59 e ss.; Rechtssystem und praktische Vernunft. Recht, Vernunft, Diskurs. Frankfurt am Main, Suhrkamp, 1995b. p. 177; Rechtsregeln und Rechtsprinzipien, Archives Rechts und Sozialphilosophie. Separata 25, Frankfurt am Main, 1995a.p. 19 e ss.; e Theorie der Grundrechte, 2. ed., [S.1], [S.d.], p. 77 e ss.

12 Idem. Rechtsregeln und Rechtsprinzipien. Archives Rechts und Sozialphilosophie. Separata 25. Frankfurt am Main, 1995. p. 17.

${ }^{13}$ Ibidem, p. 18.
} 
isso, a aplicação de um princípio deve ser vista sempre com uma cláusula de reserva, a ser assim definida: "Se no caso concreto um outro princípio não obtiver maior peso" ${ }^{14}$. Em outras palavras, quer-se dizer que a ponderação dos princípios conflitantes é resolvida mediante a criação de regras de prevalência, o que faz com que os princípios, desse modo, sejam aplicados também ao modo tudo ou nada ${ }^{15}$.

Essa espécie de tensão e o modo como ela é resolvida são o que distingue os princípios das regras: enquanto no conflito entre regras é preciso verificar se a regra está dentro ou fora de determinada ordem jurídica (problema do dentro ou fora), o conflito entre princípios já se situa no interior desta mesma ordem (teorema da coalizão) ${ }^{16}$.

Daí a definição de princípios como deveres de otimização aplicáveis em vários graus segundo as possibilidades normativas e fáticas: normativas, porque a aplicação dos princípios depende dos princípios e regras que a eles se contrapõem; fáticas, porque o conteúdo dos princípios como normas de conduta só pode ser determinado quando diante dos fatos. Com as regras acontece algo diverso. "De outro lado regras são normas, que podem ou não podem ser realizadas. Quando uma regra vale, então é determinado fazer exatamente o que ela exige, nada mais e nada menos" ${ }^{17}$. As regras jurídicas, consoante afirmado, são normas cujas premissas são, ou não, diretamente preenchidas, e no caso de colisão será a contradição solucionada seja pela introdução de uma exceção à regra, de modo a excluir o conflito, seja pela decretação de invalidade de uma das regras envolvidas ${ }^{18}$.

A distinção entre princípios e regras ${ }^{19}$ - segundo Alexy - não pode ser baseada no modo tudo ou nada de aplicação proposto por Dworkin, mas deve resumir-se, sobretudo, a dois fatores: (a) diferença quanto à colisão, na medida em que os princípios colidentes apenas têm sua realização normativa limitada reciprocamente, ao contrário das regras, cuja colisão é solucionada com a declaração de invalidade de uma delas ou com a abertura de

14 ALEXY, Robert. Rechtsregeln und Rechtsprinzipien. Archives Rechts und Sozialphilosophie, Separata 25/17, p. 18.

15 Idem. Theorie der Grundrechte. 2. ed. p. 80-83; e Zum Begriff des Rechtsprinzips. Argumentation und Hermeneutik in der Jurisprudenz, Rechtstheorie, Separata 1, p. 70.

${ }^{16}$ Idem. Rechtsregeln und Rechtsprinzipien, Archives Rechts und Sozialphilosophie, Separata 25, p. 19; e Zum Begriff des Rechtsprinzips. Argumentation und Hermeneutik in der Jurisprudenz, Rechtstheorie, Separata 1, p.70.

${ }^{17}$ Idem. Rechtsregeln und Rechtsprinzipien, Archives Rechts und Sozialphilosophie, Separata 25, p. 21.

18 Idem. Rechtssystem und praktische Vernunft, Recht, Vernunft, Diskurs, p. 216-217; e Theorie der Grundrechte, 2. ed., p. 77.

${ }^{19}$ Idem. Rechtsregeln und Rechtsprinzipien, Archives Rechts und Sozialphilosophie, Separata 25, p. 20. 
uma exceção que exclua a antinomia; (b) diferença quanto à obrigação que instituem, já que as regras instituem obrigações absolutas, não superadas por normas contrapostas, enquanto princípios instituem obrigações prima facie, na medida em que podem ser superadas ou derrogadas em face de outros princípios colidentes ${ }^{20}$.

\subsubsection{A Doutrina de Humbe rto Bergmann Ávila}

Recentemente, Humberto Bergmann Ávila apresentou estudo apontando críticas à doutrina clássica e à doutrina moderna, propondo um novo olhar sobre a teoria dos princípios, na qual teria destaque a presença de três elementos normativos: (a) regra; (b) princípio; e (c) postulado ${ }^{21}$. Com base nessa nova classificação o autor passa a explicar a relação de superação entre os elementos normativos e as propostas de interpretação defendidas.

\subsubsection{Crítica à Teoria Clássica}

De acordo com Ávila, há duas impropriedades na corrente doutrinária clássica, que sustenta que os princípios são normas de elevado grau de abstração (destinam-se a um número indeterminado de situações) e generalidade (dirigem-se a um número indeterminado de pessoas) e que, por isso, exigem uma aplicação influenciada por elevado grau de subjetividade do aplicador; contrariamente às regras, que denotam pouco ou nenhum grau de abstração (destinam-se a um número - quase - determinado de situações) e generalidade (dirigem-se a um número - quase - determinado de pessoas), e que, por isso, demandam uma aplicação com pouca ou nenhuma influência de subjetividade do intérprete.

\footnotetext{
${ }^{20}$ Á VILA, Hu mberto Berg mann. Teoria dos princípios, p. 39.

${ }^{21}$ Ibidem, passim.
} 
É dessa concepção clássica que vem a afirmação de que os princípios são os alicerces, as vigas mestras ou os valores do ordenamento jurídico, sobre o qual irradiam seus efeitos. O fundamento dessa distinção, dependendo da radicalidade com que seja defendido, segundo o autor, está no grau de indeterminação das espécies normativas: os princípios, porque fluidos, permitem maior mobilidade valorativa, ao passo que as regras, porque pretensamente determinadas, eliminam ou diminuem sobremaneira a liberdade apreciativa do aplicador. Segundo a doutrina de Ávila, trata-se de uma distinção fraca porque considera-se que os princípios e as regras têm as mesmas propriedades, embora em graus diferentes - enquanto os princípios são mais indeterminados, as regras são menos.

As inconsistências apontadas por Ávila são duas: uma semântica e outra sintática.

A inconsistência semântica reside na impropriedade da definição de princípio com base no elevado grau de abstração e generalidade. Esse critério de distinção entre as espécies normativas é inadequado porque toda norma, por ser veiculada por meio da linguagem, é, em alguma medida, indeterminada, sendo descabido, portanto, fazer uma distinção entre as espécies normativas com base em algo que é comum a todas elas - a indeterminação. E como a aplicação das normas demanda amplo processo de ponderação de razões e fatos, tanto a aparente determinação pode desaparecer quanto a pressuposta indeterminação pode transmudar-se em clareza diante dos casos concretos. Até mesmo porque a aplicação das normas abrange vários outros aspectos além do meramente semântico.

O mesmo ocorre com relação ao conteúdo valorativo. Toda norma, porque destinada a atingir determinada finalidade, serve de meio para a concretização de, no mínimo, dois valores: (a) o valor formal da segurança, pois as regras têm uma pretensão de decidibilidade inexistente no caso dos princípios; e (b) o valor substancial específico, já que cada regra tem uma finalidade que lhe é subjacente. Por essa razão, descabe fundar uma distinção entre as espécies normativas no conteúdo valorativo se ele, em vez de estremá- las, termina aproximando-as.

Note-se que a distinção entre as espécies normativas com repercussão nos planos da indeterminação e do conteúdo valorativo da linguagem pode terminar, de um lado, apequenando a latente indeterminação das regras e seu encoberto conteúdo valorativo, transformando-as em normas de segunda categoria pela sua pretensa determinação e pela sua suposta neutralidade valorativa. Mais que isso: essa distinção pode levar à crença de 
que o intérprete não tem liberdade alguma de configuração dos conteúdos semântico e valorativo das regras, quando, em verdade, toda norma jurídica - inclusive as regras - só tem seu conteúdo de sentido e sua finalidade subjacente definidos mediante um processo de ponderação. De outro lado, esse critério de distinção pode conduzir, mediatamente, a uma supervalorização dos princípios, como se a aplicação de qualquer regra pudesse ser alçada ao nível exclusivamente principioló gico sem justificação nem fundamentação.

Prossegue Ávila afirmando que a inconsistência semântica traz implicações no plano sintático, pois, muitos autores que definem os princípios como aquelas normas portadoras de propriedades específicas - elevado grau de abstração e generalidade insistem em qualificar de "princípios" normas que não têm aquelas propriedades. Ora, se princípio é definido como uma norma de elevado grau de abstração e generalidade e que, por isso, exige uma aplicação com elevado grau de subjetividade, colocam-se as seguintes indagações: a prescrição normativa permitindo o abatimento do imposto sobre produtos industrializados a pagar do montante incidente nas operações anteriores pode ser considerada um princípio? A prescrição normativa que exige a publicação da lei que instituiu ou aumentou um imposto até o final do exercício anterior ao da cobrança pode ser considerada um princípio? A prescrição normativa que proỉbe o legislador de tributar fatos ocorridos antes da edição da lei pode ser considerada um princípio? A prescrição normativa que próibe a instituição de imposto sobre determinados fatos pode ser considerada um princípio? A proibição de utilização de prova ilícita pode ser considerada um princípio? A resposta a essas perguntas é: evidente que não. Coloca-se, ainda, a seguinte pergunta: onde estão as referidas propriedades de elevado grau de abstração e generalidade no caso da norma que exige a anterioridade para a instituição ou aumento de impostos, por exemplo? Elas não estão presentes em lugar algum. A norma que exige o comportamento de publicar a lei que instituiu ou aumentou um imposto até o final do exercício anterior ao da cobrança é uma regra, por exemplo ${ }^{22}$.

De acordo com Ávila, essa contradição interna da doutrina não diz respeito a uma mera questão de nomenclatura, de resto secundária. Tratar-se-ia de uma disputa terminológica se não surgissem dois problemas fundamentais: de um lado, se não fossem atreladas às normas comentadas determinadas propriedades que elas, em verdade, não têm - alto grau de generalidade e abstração; de outro lado, se não fosse atrelada à definição das

22 Á VILA, Hu mberto Berg mann. Sistema constitucional tributário. 4. ed. São Paulo: Saraiva, 2010. p. 157. 
referidas normas uma consequência específica para sua aplicação - alto grau de subjetividade. Em sendo essas as características, a doutrina, de um lado, cai em contradição e, de outro - o que é bem pior -, legitima a flexibilização na aplicação de uma norma que a Constituição Federal brasileira, pela técnica de normatização que utilizou, queria menos flexível ${ }^{23}$.

\subsubsection{Crítica à Teoria de Ronald Dworkin e Robert Alexy}

Ao reportar-se à doutrina moderna, Ávila apresenta igualmente críticas à teoria defendida por Dworkin e Alexy, sobretudo no que tange à afirmação de que somente os princípios admitiriam ponderações, ao passo que eventual antinomia entre as regras implicaria decretação da invalidade da regra colidente.

Essa inconsistência semântica pode ser vista na situação em que duas regras abstratamente harmoniosas - submetem-se a uma ponderação externa. Trata-se da hipótese em que essas duas normas entram em conflito diante do caso concreto sem que a solução para o conflito envolva a decretação de invalidade de uma das duas regras - por exemplo: uma regra determina a concessão da antecipação de tutela para evitar dano irreparável e outra regra proß̉be a antecipação se ela provocar despesas para a Fazenda Pública. É inapropriado, por isso, fazer uma distinção entre as espécies normativas com base em propriedades comuns às espécies diferenciadas - a ponderabilidade e a superabilidade ${ }^{24}$.

Tecidas essas considerações, passa-se à análise da tese defendida por Humberto Ávila que servirá de premissa para o presente estudo.

\footnotetext{
${ }^{23}$ Á VILA, Hu mberto Berg mann. Teoria dos princípios, p. 86.

${ }^{24}$ Ibidem, p. 53.
} 


\subsubsection{Proposta de Distinção entre Regras e Princípios}

A proposta defendida por Ávila diferencia-se das demais vistas de maneira resumida anteriormente porque admite a coexistência das espécies normativas em razão de um mesmo dispositivo. Segundo o autor ${ }^{25}$, um ou mais dispositivos podem funcionar como ponto de referência para construção de regras, princípios e postulados. Ao invés de alternativas exclusivas entre as espécies normativas (se regra ou princípio), de modo que a existência de uma espécie excluiria a existência das demais, propõe-se uma classificação que alberga alternativas inclusivas, no sentido de que os dispositivos podem gerar, simultaneamente, mais de uma espécie normativa. Um ou vários dispositivos, ou mesmo a implicação lógica deles decorrentes, pode experimentar uma dimensão imediatamente comportamental (regra), finalística (princípio) e/ou metódica (postulado).

Em razão disso, propõe-se o exame, por exemplo, do dispositivo constitucional segundo o qual é exigida lei em sentido formal para a instituição ou aumento de tributos. É plausível examiná- lo como regra, como princípio e como postulado. Como regra, porque condiciona a validade da criação ou aumento de tributos à observância de um procedimento determinado que culmine com a aprovação de uma fonte normativa específica - a lei; como princípio, porque estabelece como devida a realização dos valores de liberdade e de segurança jurídica; e como postulado, porque vincula a interpretação e a aplicação à lei e ao Direito, pré-excluindo a utilização de parâmetros alheios ao ordenamento jurídico.

Ao seguir em sua exposição, o autor sugere a análise do dispositivo constitucional segundo o qual todos devem ser tratados com equidade. É plausível aplicá-lo como regra, como princípio e como postulado. Como regra, porque proíbe a criação ou aumento de tributos que não sejam iguais para todos os contribuintes; como princípio, porque estabelece como devida a realização do valor da igualdade; e como postulado, porque institui um dever jurídico de comparação (Gebot der Vergleichung) a ser seguido na interpretação e aplicação, pré-excluindo critérios de diferenciação que não sejam aqueles previstos no próprio ordenamento jurídico ${ }^{26}$.

\footnotetext{
25 Á VILA, Hu mberto Berg mann. Teoria dos princípios, p. 69.

${ }^{26}$ MICHAEL, Lothar. Der allgemeine Gleichheitssatz als Methodennorm komparativer Systeme. Berlin: Duncker und Hu mblot, 1997. p. 48.
} 
Com essas considerações, Ávila propõe ${ }^{27}$ tese no sentido de se superar um modelo dual de separação regras/princípios, sugerindo a adoção de um modelo tripartite de dissociação regras/princípios/postulados, que, além de dissociar as regras dos princípios no tocante ao dever que instituem, à justificação que exigem e ao modo como contribuem para solucionar conflitos, acrescenta a essas categorias normativas a figura dos postulados, definidos como instrumentos normativos metódicos, isto é, como categorias que impõem condições a serem observadas na aplicação das regras e dos princípios, com eles não se confundindo $^{28}$.

\subsection{Distinção entre Regras e Princípios - Definição de Postulados}

Em primeiro lugar, as regras diferenciam-se dos princípios pela natureza da descrição normativa: enquanto as regras descrevem objetos determináveis (sujeitos, condutas, matérias, fontes, efeitos jurídicos, conteúdos), os princípios descrevem um estado ideal de coisas a ser promovido.

Em segundo lugar, as regras diferenciam-se dos princípios pela natureza da justificação que exigem para serem aplicadas: as regras exigem um exame de correspondência entre a descrição normativa e os atos praticados ou fatos ocorridos, ao passo que os princípios exigem uma avaliação da correlação positiva entre os efeitos da conduta adotada e o estado de coisas que deve ser promovido.

Em terceiro lugar, as regras distinguem-se dos princípios pela natureza da contribuição para a solução do problema: enquanto as regras têm pretensão de decidibilidade, pois visam proporcionar uma solução provisória para um problema conhecido ou antecipável, os princípios têm a pretensão de complementariedade, já que servem de razões a serem conjugadas com outras para a solução de um problema ${ }^{29}$.

Dessas constatações, Ávila apresenta uma proposta conceitual de regra e de princípios, consoante a seguir:

\footnotetext{
27 Á VILA, Hu mberto Berg mann. Teoria dos princípios, p. 71.

28 Idem. A distinção entre princípios e regras e a redefinição do dever de proporcionalidade. Revista de Direito Administrativo, Rio de Janeiro, n. 215, p. 151-152, jan./mar. 1999.

29 Á VILA, Hu mberto Berg mann. Op. cit., p. 84.
} 
“[...] as regras são normas imediatamente descritivas, primariamente retrospectivas e com pretensão de decidibilidade e abrangência, para cuja aplicação se exige a avaliação da correspondência, sempre centrada na finalidade que thes dá suporte ou nos princípios que lhes são axiologicamente sobrejacentes, entre a construção conceitual da descrição normativa e a construção conceitual dos fatos.

Os princípios são normas imediatamente finalísticas, primariamente prospectivas e com pretensão de complementariedade e de parcialidade, para cuja aplicação se demanda uma avaliação da correlação entre o estado de coisas a ser promovido e os efeitos decorrentes da conduta havida como necessária à sua promoção" ${ }^{30}$.

Desse modo, as regras e os princípios seriam normas de primeiro grau, ao passo que os postulados seriam as normas de segundo grau. Ávila explica que a interpretação de qualquer objeto cultural submete-se a algumas condições essenciais, sem as quais o objeto não pode ser sequer apreendido. A essas condições gerais dá-se o nome de postulados. Há os postulados hermenêuticos, destinados à compreensão em geral do Direito, e os postulados aplicativos, cuja função é estruturar a sua aplicação concreta - por exemplo, o postulado da unidade do ordenamento jurídico, a exigir do intérprete o relacionamento entre a parte e o todo mediante o emprego das categorias de unidade e ordem.

Os postulados normativos aplicativos - por exemplo, a proporcionalidade, a razoabilidade e a proibição de excesso - são normas "imediatamente metodológicas" que instituem os critérios de aplicação de outras normas situadas no plano do objeto de aplicação. Qualificam-se, assim, como normas sobre a aplicação de outras normas, isto é, metanormas - daí dizer-se que se qualificam como normas de segundo grau. Nesse sentido, sempre que se está diante de um postulado normativo, há uma diretriz metódica que se dirige ao intérprete relativamente à interpretação de outras normas. Subjacentes aos postulados, há sempre outras normas que estão sendo aplicadas.

${ }^{30}$ Á VILA, Hu mberto Berg mann. Teoria dos princípios, p. 79. 


\subsubsection{Prevalência das Regras sobre Princípios}

Após estabelecer a distinção entre regras e princípios, prossegue Ávila com o propósito de desconstituir a concepção doutrinária largamente difundida de que descumprir um princípio seria mais grave que descumprir uma regra.

De acordo com o autor, em geral, o correto é o contrário: descumprir uma regra é mais grave que descumprir um princípio. E isso porque, como dito, as regras têm uma pretensão de decidibilidade que os princípios não possuem: enquanto as regras têm a pretensão de oferecer uma solução provisória para um conflito de interesses já conhecido ou antecipável pelo Poder Legislativo, os princípios apenas oferecem razões complementares para solucionar um conflito futuramente verificável.

Também relacionado a essa questão está o problema de saber qual norma deve prevalecer se houver conflito entre um princípio e uma regra do mesmo nível hierárquico regra constitucional versus princípio constitucional. Em rigor, a doutrina, com base naquela já referida concepção tradicional, afirma que deve prevalecer o princípio. Assim, porém, não deve suceder, pois, se isso fosse aceito, explica o autor ${ }^{31}$, quando houvesse colisão entre a regra de imunidade dos livros e o princípio da liberdade de manifestação do pensamento e de cultura, deveria ser atribuída prioridade ao princípio, inclusive - esta seria uma das consequências - para efeito de tornar imunes obras de arte. E se houvesse conflito entre a regra de competência para instituir contribuições sociais sobre faturamento e os princípios da solidariedade social e da universalidade do financiamento da seguridade social, segundo o autor, deveria ser dada prevalência aos princípios, inclusive - este seria um dos resultados - para o efeito de justificar a tributação mesmo que o valor obtido pela empresa não fosse enquadrado no conceito de faturamento.

Ora, isso não seria aceitável. O próprio Supremo Tribunal Federal (STF) afastou essa prevalência dos princípios em importante precedente ${ }^{32}$ e, de maneira indireta, no julgamento da Ação Direta de Inconstitucionalidade (ADIn) no 815, por meio da qual um ente federado (Estado do Rio Grande do Sul) arguiu a inconstitucionalidade de uma regra constitucional sobre proporcionalidade de representação no Congresso Nacional, em face

\footnotetext{
31 Á VILA, Hu mberto Berg mann. Teoria dos princípios, p. 91.

32 Supremo Tribunal Federal - STF, Tribunal Pleno, RE 346.084, rel. Min. Ilmar Galvão, rel. para o acórdão Min. Cezar Pelu zo, DJU 1.9.2006.
} 
do próprio princípio federativo. O colendo Tribunal decidiu extinguir a ação, por impossibilidade jurídica do pedido, por entender que não poderia afastar, com base em um princípio, a concretização definitória escolhida pelo Poder Constituinte Originário mediante regras constitucionais. Assim, entendeu-se que o Poder Constituinte instituiu o princípio federativo, mas o fez conforme estabelecido na regra prevista no art. 45 da $\mathrm{CF}$, e com as restrições ali estabelecidas.

Da decisão em comento, pode-se concluir que não é permitido a outro Poder rever a "ponderação" realizada pelo próprio Poder Constituinte Originário. Tanto é assim que o acórdão menciona, à fl. 347, que o princípio da igualdade está limitado pela própria Constituição no art. 5ำ, inciso I, ou que o princípio democrático está limitado pela própria Constituição no art. $1^{\underline{o}}$ ("nos termos desta Constituição"). Do mesmo modo, foi acolhido o parecer da Advocacia-Geral da União no sentido de que "a tese defendida pelo autor sobre a possibilidade de existência de disposições inconstitucionais diante de normas tidas como de hierarquia superior não é aceitável" (fl. 318). Por fim, o STF entendeu que o Poder Constituinte é livre para fixar os limites de um princípio constitucional, já que "quem é livre para fixar um princípio o é também para impor-lhe exceções” (fl. 325). Essas exceções são estabelecidas por meio de regras. Pode-se afirmar que o STF, com outras palavras, decidiu que o aplicador - seja ele tanto o Poder Judiciário como o Poder Legislativo - não pode afastar uma regra com base em um princípio constitucional, em razão do caráter definitório e decisivo das regras ${ }^{33}$.

\subsubsection{Procedime nto de Superabilidade das Regras}

Por derradeiro, resta investigar em que situações as regras poderão ser superadas e em que condições. Ainda consoante as bases conceituais propostas por Ávila, a superação das regras somente poderá ocorrer se preenchidos dois requisitos concomitantemente, sendo o primeiro de natureza material (conteúdo) e o segundo de natureza procedimental (requisitos e forma).

33 Á VILA, Hu mberto Berg mann. Teoria dos princípios, p. 107. 


\subsection{Requisitos Materiais}

Sendo as regras instrumentos de solução previsível, eficiente e em rigor equânime de conflitos, sua superação será tanto mais flexível quanto menos imprevisibilidade, ineficiência e desigualdade geral ela provocar. $\mathrm{O}$ exame de dois exemplos diferentes pode explicar o grau de resistência das regras.

No primeiro exemplo, uma regra condicionava o ingresso em um programa de pagamento simplificado de tributos federais à ausência de importação de produtos estrangeiros. Os participantes do programa não poderiam efetuar operações de importação, sob pena de exclusão. Essa a hipótese da regra. O caso concreto diz respeito a uma pequena fábrica de sofás que efetuou uma importação e foi, em decorrência disso, sumariamente excluída do programa. Ocorre, no entanto, que a importação foi de quatro pés de sofás, para um só sofá, feita uma única vez. Mediante recurso, a exclusão foi anulada com base na falta de aplicação razoável da regra. Nesse caso, o fato previsto na hipótese da regra ocorreu, mas a consequência de seu descumprimento não foi aplicada (exclusão do regime tributário especial) porque a falta de adoção do comportamento por ela previsto não comprometia a promoção do fim que a justificava (estímulo da produção nacional por pequenas empresas) $)^{34}$.

Em outras palavras, segundo a proposta de superação de regras do autor, a aceitação desse caso individual não prejudicou a implementação dos dois valores inerentes à regra: (a) o valor formal da segurança não é restringido, porque a circunstância particular não seria facilmente reproduzível por outros contribuintes; e (b) o valor substancial de estímulo à produção nacional não seria reduzido, porque o comportamento permitido levaria à sua promoção. A tentativa de fazer justiça para um caso mediante superação de uma regra não afetaria a promoção da justiça para a maior parte dos casos. E o entendimento contrário, no sentido de não superar a regra, provocaria mais prejuízo valorativo que benefício (more harm than good).

Explica o autor que o mesmo não se passa para outro tipo de situação. No segundo exemplo, uma regra condicionava apresentação de determinado recurso à juntada de cópias legíveis da decisão recorrida e dos documentos que comprovassem a discussão existente nos autos. $\mathrm{O}$ caso concreto diz respeito a um recurso apresentado sem a juntada da cópia da

${ }^{34}$ Á VILA, Hu mberto Berg mann. Teoria dos princípios, p. 115/116. 
petição e do despacho que a indeferiu. Inconformado com o indeferimento, o recorrente interpôs recurso, alegando violação ao princípio da universalidade da jurisdição e excessivo formalismo na interpretação da regra que exigia a juntada de documentos. $\mathrm{O}$ Tribunal, contudo, manteve a decisão, sob o argumento de que o recorrente deve instruir seu recurso com todas as peças essenciais ao entendimento do assunto nele tratado, já que essa exigência não está a serviço do formalismo inconsequente, mas da segurança das partes e do devido processo legal ${ }^{35}$. Nesse caso, o fato previsto na hipótese da regra ocorreu, e a consequência do seu descumprimento, apesar do prejuízo da parte, foi aplicada (inadmissão do recurso interposto), porque a falta de adoção do comportamento por ela previsto comprometia a promoção do fim que a justificava (segurança das partes).

O exame dos casos ora referidos demonstra que o grau de resistência de uma regra à superação está vinculado tanto à promoção do valor subjacente à regra (valor substancial específico) quanto à realização do valor formal subjacente às regras (valor formal de segurança jurídica). E o grau de promoção do valor segurança está relacionado à possibilidade de seu reaparecimento frequente em situação similar.

A soma desses fatores permite afirmar-se que a resistência à superação de uma regra será tanto maior quanto mais importante for a segurança jurídica para sua interpretação.

Explica Ávila que a segurança jurídica será tanto mais importante, em primeiro lugar, quanto maior for o valor subjacente do princípio da segurança para a interpretação da matéria veiculada pela regra. Isso ocorre, por exemplo, nos setores do ordenamento jurídico em que o princípio da segurança jurídica exerce papel primordial, como no Direito Penal e no Direito Tributário. Nesses campos normativos a padronização é importante, devendo a rigidez ser tanto maior quanto maior for a necessidade de generalização e quanto menos danosa for a decisão individual para a implementação do princípio geral da igualdade.

Em segundo lugar, a segurança jurídica será tanto mais importante quanto maior for a vinculação desse valor sobrejacente com o valor sobrejacente à regra. Isso surge quando o princípio da segurança jurídica é importante para o setor no qual a regra se insere, e a finalidade subjacente à regra está relacionada com a promoção da segurança.

\footnotetext{
${ }^{35}$ Superior Tribunal de Justiça - STJ, $1^{\mathbf{a}}$ Turma, AgR nos ED no AI 633.751-MG, rel. Min. Luiz Fux, j. 7.4.2005, DJU 2.5.2005, p. 183.
} 
A resistência à superação será, assim, muito pequena naqueles casos em que o alargamento ou restrição da hipótese da regra em razão da sua finalidade forem indiferentes ao valor segurança jurídica; e será tanto maior quanto mais a superação comprometer a realização do valor segurança jurídica. Isso porque as regras configuram meios utilizados pelo Poder Legislativo para, de um lado, eliminar ou reduzir a controvérsia, a incerteza e a arbitrariedade e, de outro, evitar problemas de coordenação, de deliberação e de conhecimento existentes em um modelo particularístico de decisão. As regras são, portanto, instrumentos de justiça geral.

O grau de resistência da regra deverá ser tanto superior quanto mais a tentativa de fazer justiça para um caso mediante superação de uma regra afetar a promoção da justiça para a maior parte dos casos; e deverá ser tanto inferior quanto menos a tentativa de fazer justiça para um caso afetar a promoção da justiça para a maior parte dos $\operatorname{casos}^{36}$. Isso porque a superação de uma regra não se circunscreve à solução de um caso, como ocorre na ponderação horizontal entre princípios mediante a criação de regras concretas de colisão; mas exige a construção de uma solução de um caso mediante a análise da sua repercussão para a maioria dos casos. A decisão individualizante de superar uma regra deve sempre levar em conta seu impacto para aplicação das regras em geral. A superação de uma regra depende da aplicabilidade geral das regras e do equilíbrio pretendido pelo sistema jurídico entre justiça geral e justiça individual ${ }^{37}$.

\subsection{Requisitos Procedimentais}

As considerações anteriores demonstram que as regras, em geral, podem ser superadas, desde que presentes determinados requisitos.

A superação de uma regra deverá ter, em primeiro lugar, uma justificativa condizente. Essa justificativa depende de dois fatores. Primeiro, da demonstração de incompatibilidade entre a hipótese da regra e sua finalidade subjacente. É preciso apontar a discrepância entre aquilo que a hipótese da regra estabelece e o que sua finalidade exige.

\footnotetext{
36 Á VILA, Hu mberto Berg mann. Teoria dos princípios, p. 118.

${ }^{37}$ Ibidem, p. 119.
} 
Segundo, da demonstração de que o afastamento da regra não provocará expressiva insegurança jurídica. Com efeito, as regras configuram meios utilizados pelo Poder Legislativo para eliminar ou reduzir a controvérsia, a incerteza e a arbitrariedade e evitar problemas de coordenação, de deliberação e de conhecimento.

Nesse caso, a superação das regras exige a demonstração de que o modelo de generalização não será significativamente afetado pelo aumento excessivo das controvérsias, da incerteza e da arbitrariedade, nem pela grande falta de coordenação, pelos altos custos de deliberação ou por graves problemas de conhecimento. Enfim, a superação de uma condiciona-se à demonstração de que a justiça individual não afeta substancialmente a justiça geral.

Em segundo lugar, a superação de uma regra deverá ter uma fundamentação condizente: é preciso exteriorizar, de modo racional e transparente, as razões que permitem a superação. Vale dizer, uma regra não pode ser superada sem que as razões de sua superação sejam exteriorizadas e possam, com isso, ser controladas. A fundamentação deve ser escrita, juridicamente fundamentada e logicamente estruturada.

Em terceiro lugar, a superação de uma regra deverá ter uma comprovação condizente: não sendo necessárias, notórias nem presumidas, a ausência do aumento excessivo das controvérsias, da incerteza e da arbitrariedade e a inexistência de problemas de coordenação, altos custos de deliberação e graves problemas de conhecimento devem ser comprovadas por meios de prova adequados, como documentos, perícias ou estatísticas. A mera alegação não pode ser suficiente para superar uma regra ${ }^{38}$.

\subsection{Os Princípios da Constituição Federal de 1988}

Delimitada a função da regra, do princípio e do postulado, impende destacar que a Constituição Federal é repleta de princípios, explícitos e também implícitos, conforme

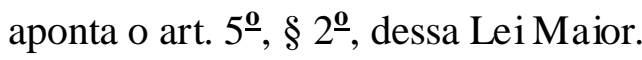

38 Á VILA, Hu mberto Berg mann. Teoria dos princípios, p. 120. 
O princípio da confiança legítima, que tem relevância especial para este trabalho, tanto nas ordens jurídicas europeias e americanas, como também na brasileira, ocupa a posição de princípio implícito ${ }^{39}$ o que não contraria em nada a sua efetividade e a natureza própria dos princípios. Os ordenamentos positivos não o consagram expressamente. Esse o traço comum nas ordens jurídicas contemporâneas. Em decorrência, ele costuma se acostar e fundar os direitos fundamentais dos contribuintes, além de ser invocado, subsidiariamente, todas as vezes em que o modelo constitucional dessas garantias ou das limitações ao poder de tributar é frágil.

Essa é uma questão que preocupa, por exemplo, alguns juristas germânicos: o princípio da proteção da confiança é um princípio em si mesmo, como direito e garantia fundamental? Ou ele configura um desdobramento da legalidade ou da irretroatividade? Ou ainda uma expressão do direito de propriedade, do direito à personalidade ou à dignidade humana, ou ainda à igualdade?

Ora, nem sempre princípios e direitos fundamentais encontram regulação tão completa e farta, como ocorre na Constituição brasileira que transforma alguns princípios em regras constitucionais - ditando-lhes as exceções (essa a posição da legalidade e da proibição de retroação) ou consagra princípios expressos já lhes ditando os contraprincípios. Na ordem jurídica nacional, ver-se-á que o princípio da confiança tem dimensão menor porquanto a Constituição Federal já proteja o contribuinte em inúmeras situações, o que torna desnecessária a invocação do princípio em estudo.

Assim, o campo de aplicação do princípio da confiança, na ordem constitucional brasileira, como princípio implícito, ético-jurídico geral, não coincide com a extensão que lhe é concedida em outros ordenamentos positivos. Inexiste, na verdade, fragilidade decorrente do princípio da proteção da confiança no País, mas força e riqueza surpreendentes dos demais direitos e garantias fundamentais do contribuinte.

\footnotetext{
39 Conforme salienta Misabel Derzi, na Constituição Federal "há também princípios dessa natureza, imprecisos ou indeterminados, como a função social da propriedade e outros, decorrentes da ordem econômica e social. Outros princípios não estão sequer expressos, mas são deduzidos implicitamente do sistema jurídico. A proteção da confiança e a praticidade, por exemplo, não têm formulação normativa expressa, embora estejam diluídos na ordem jurídica como tendência marcante. Os princípios serão de origem, então, dogmática, se referidos pela Ciência do Direito, racionais, quando impostos pela Lógica jurídica, ou jurisprudenciais, se firmados na prática dos Tribunais." (DERZI, Misabel Abreu Machado. Modificações da jurisprudência: proteção da confiança, boa-fé objetiva e irretroatividade como limitações constitucionais ao poder judicial de tributar. São Paulo: Noeses, 2009. p. 147).
} 
Ora, o mesmo já não se pode falar do Direito alemão, cuja Constituição consagra a legalidade dos atos administrativos - sem ditar-lhes as exceções específicas, como seria o caso das graduações de alíquotas em certos tributos - ou da proibição de retroação, que somente está prevista para as leis penais. Mediante o princípio da proteção da confiança, da boa-fé, ou da segurança em sentido lato, a Corte Constitucional alemã estendeu a irretroatividade no Direito Penal para os demais ramos do Direito e ainda mais, para proteger os cidadãos contra as reviravoltas jurisprudenciais, atribuindo, por meio de construções criativas, a estabilidade que o Estado de Direito pressupõe.

Nos capítulos seguintes, relacionar-se-á o princípio da confiança legítima com as práticas reiteradamente observadas pelas autoridades administrativas em matéria tributária, a teor do art. 100, inciso III, do CTN. 


\section{CAPÍTULO 2}

\section{PRINCÍPIO DA CONFIANÇA LEGÍTIMA E BOA-FÉ}

O princípio da confiança legítima tem por finalidade a defesa do particular naquelas situações em que o indivíduo acreditou na validade de ato da Administração Pública que mais tarde se revelou ilegal.

O princípio em foco protege, assim, aquele que criou expectativa legítima no que tange à correção do comportamento da Administração Pública e teve essa confiança frustrada. Essa confiança decorre do fato de que os atos do Poder Público gozam da aparência e da presunção de legitimidade, o que passa a justificar, em diferentes situações, sua conservação no mundo jurídico, mesmo quando esses atos se apresentem eivados de graves vícios.

Essa questão jurídica, em si, não é nova. O exemplo mais antigo e, talvez, mais célebre do que se acaba de afirmar está no fragmento de Ulpiano, constante do Digesto, sob o título "de ordo praetorum" (D.1.14.1), no qual o eminente jurista clássico narra o caso do escravo Barbarius Philippus que foi nomeado pretor em Roma. Indaga Ulpiano: "Que diremos do escravo que, conquanto ocultando essa condição, exerceu a dignidade pretória? O que editou, o que decretou, terá sido talvez nulo? Ou será válido por utilidade daqueles que demandaram perante ele, em virtude de lei ou de outro direito?". E Ulpiano responde pela afirmativa.

Não é outra a solução que tem sido dada, até hoje, para os atos praticados por "funcionário de fato". Esses atos são considerados válidos, em razão - costuma-se dizer da "aparência de legitimidade" de que se revestem, apesar da incompetência absoluta de quem os exarou. $\mathrm{Na}$ verdade, o que o direito protege não é a "aparência de legitimidade" daqueles atos, mas a confiança gerada nas pessoas em virtude ou por força da presunção de legalidade e da aparência de legitimidade que têm os atos do Poder Público.

Se a questão, como dito, não é nova, ela também está longe de ser ultrapassada. É que, de maneira recorrente, cada vez mais os Tribunais Superiores têm sido convocados a 
solucionar as questões ligadas à manutenção ou não de atos ilegais, consoante se verifica do seguinte aresto:

\begin{abstract}
"Administrativo. Funcionário de fato. Investidura baseada em norma posteriormente declarada inconstitucional. A nulidade não envolve uma das fases de ato complexo, de mera execução de ordem legítima, com a sua consequência normal e rotineira. Aparência de legalidade e inexistência de prejuízo.

$[\ldots]$

Toda nulidade há de corresponder a uma finalidade prática. Não se decreta nulidade simplesmente pelo amor à formalidade que poderia ter sido repetida nas mesmas condições, com ratificação do efeito produzido. Assim, Sr. Presidente, a despeito das judiciosas considerações do eminente Relator, acho o caso compatível com um entendimento mais simples: o funcionário, não autorizado, tinha a seu favor a presunção de legitimidade, porque havia uma disposição regulamentar estadual que previa tal atuação,"40.
\end{abstract}

Dada a atualidade do assunto, o princípio da confiança legítima tem sido frequentemente arguido no Tribunal de Luxemburgo da União Europeia e sua menção já ultrapassa mais de dez por cento de todas as decisões desse Tribunal ${ }^{41}$.

Esse princípio, herdado do direito alemão, é considerado uma manifestação subjetiva de segurança jurídica da ordem jurídica e tem recebido aplicação geralmente em inúmeros casos envolvendo a retroatividade de leis, erros de autoridades, crença legítima na aparência jurídica, motivação de decisões, contradições de atos administrativos, práticas reiteradas da Administração e mudanças de critérios de tratamento contra os $\operatorname{administrados}^{42}$.

O princípio da confiança é também inúmeras vezes confundido com a boa-fé, de tal sorte que algumas ponderações a respeito dos dois institutos são pertinentes.

"Boa-fé", "segurança jurídica" e "proteção à confiança" são, pois, ideias que exprimem a mesma ordem de valores; contudo, no curso do tempo, cada uma dessas ideias

40 RECURSO EXTRAORDINÁRIO no ${ }^{0}$ 78.533/SP. 2 ${ }^{-}$Turma, Relator Ministro Décio Miranda. Revista Trimestral de Jurisprudência, $\mathrm{n}$ 을 100, p. 1.086/1.091, jun. 1982.

${ }^{41}$ Cf. SCHONBERG, Soren. Legitimate expectations in administrative law. Oxford: Oxford University Press, 2000.

42 TORRES, Heleno Taveira. Direito constitucional tributário e segurança jurídica: metódica da segurança jurídica do Sistema Constitucional Tributário. 2. ed. São Paulo: Revista dos Tribunais, 2012. p. 220. 
foi se particularizando, diferenciando-se umas das outras, sem se distanciarem completamente.

A boa-fé ${ }^{43}$ é noção que, desde o mundo romano, consolidou-se no direito privado, seja no sentido subjetivo, como aparece, por exemplo, na posse ad usucapionem, seja no sentido objetivo, que começa a ser modelado no que diz respeito à lealdade, correção e lisura do comportamento das partes reciprocamente consideradas. Nessa segunda acepção, de boa-fé objetiva, foi ela recebida pelo Código Civil de 2002, notadamente nos arts. 113 e $422^{44}$

Conquanto a boa-fé objetiva tenha um destaque maior no campo do direito das obrigações, sobretudo em face do amplo espectro de "deveres anexos" que a ela se vinculam e do papel que desempenha como base teórica da culpa in contrahendo, é irrecusável, nos dias atuais, sua importância em todo o território do direito privado, mas também no campo do direito público, podendo ser percebida nos contratos administrativos e na responsabilidade pré-negocial do Estado ${ }^{45}$.

É substancialmente essa mesma concepção de que, nas relações jurídicas, as partes devem proceder com correção, lealdade e lisura, em conformidade com o que se

\footnotetext{
43 Talvez o estudo mais completo sobre a origem da boa-fé e seu desenvolvimento histórico tenha sido realizado por Menezes Cordeiro. Ensina o autor que já o Direito Romano disciplina a boa-fé em três dimensões diversas: fides-sacra; fides-fato; fides-ética (MENEZES CORDEIRO, Antonio M. Da boa-fé no direito civil. Coimbra: Almedina, 1989. v. 1). A prime ira vinculava-se ao campo religioso, e, a segunda, aos clientes e garantias; a terceira configura um dever ligado à garantia. Assim, pela referida cláusula bona fides, o juiz não se limitava a examinar o contrato segundo o seu enunciado linguístico literal, mas dispunha de uma "bitola especialmente lata de decisão". Especial significado tinha então a cláusula do oportet ex fide bona, pois, por meio dela, exig ir-se-ia uma re lação pautada na honestidade e na lealdade (CAMPOS, Miriam de A. Machado e. O princípio da boa-fé objetiva. No prelo, p. 2.). As origens da boa-fé germân ica estão exatamente no Direito Romano. Esse viés da boa-fé, como garantia, jamais se perdeu, já que Canaris dele se utiliza para reforçar as garantias deixadas frágeis pelo legislador, ou seja, ele aplica a responsabilidade por força de necessidade ético-jurídica como elemento subsidiário que se manifesta apenas onde as possibilidades de segurança, reguladas pela ordem jurídica, "fracassam ético-juridicamente" (DERZI, Misabel Abreu Machado. Modificações da jurisprudência: proteção da confiança, boa-fé objetiva e irretroatividade como limitações constitucionais ao poder judicial de tributar, p. 363/364). Explica Menezes Cordeiro que a boa-fé objetiva somente atingirá um emprego técnico com a codificação alemã, pois um conjunto de valores novos vieram no decorrer da Idade Média. "A honra, a lealdade e o respeito ligado às juras solenemente proferidas, tipicamente medievais. Sua persistência na Alemanha deveu-se à romanização tardia, bem como à permanência mais prolongada das características medievais. Frisa Menezes Cordeiro que os traços fundamentais da boa-fé germânica, no emprego medieval, são a objetividade e o nacionalismo. Tornou-se um elemento afetivo (OLIVEIRA, Ubirajara Mach de. Princípios informadores do sistema de direito privado: a autonomia da vontade e a boa-fé objetiva. Revista de Direito do Consumidor, Revista de São Paulo: RT, n. 23-24, p. 56-60, p. 56-60, jul./dez. 1997).

44 “Art. 113. Os negócios jurídicos devem ser interpretados conforme a boa-fé e os usos do lugar de sua celebração."; e "Art. 422. Os contratantes são obrigados a guardar, assim na conclusão do contrato, como em sua execução, os princípios de probidade e boa-fé.”.

45 COUTO E SILVA, Almiro do. A responsabilidade pré-negocial no direito administrativo brasileiro. RDA, n. 217, p. 163-171, 1999.
} 
comprometeram e com a palavra empenhada que, em última análise, dá conteúdo ao princípio da segurança jurídica, pelo qual, nos vínculos entre o Estado e os indivíduos, assegura-se certa previsibilidade da ação estatal, do mesmo modo que se garante o respeito pelas situações constituídas em consonância com as normas impostas ou reconhecidas pelo Poder Público, de modo a assegurar a estabilidade das relações jurídicas e certa coerência na conduta do Estado ${ }^{46}$.

Há, no entanto, uma separação entre boa-fé e segurança jurídica. De acordo com Couto e Silva, a segurança jurídica é compreendida atualmente como sendo um conceito ou um princípio jurídico que se ramifica em duas vertentes, sendo uma de natureza objetiva e outra de natureza subjetiva. A primeira - de natureza objetiva - é aquela que envolve a questão dos limites à retroatividade dos atos do Estado até mesmo quando estes se qualifiquem como atos legislativos (proteção ao direito adquirido, ao ato jurídico perfeito e à coisa julgada ${ }^{47}$ ). A outra - de natureza subjetiva - refere-se exatamente à proteção à confiança das pessoas no que tange aos atos, procedimentos e condutas do Estado, nos mais diferentes aspectos de sua atuação.

Modernamente a doutrina prefere admitir a existência de dois princípios distintos, apesar das estreitas correlações existentes entre eles. Assim, diz-se em princípio da segurança jurídica quando se designa o que prestigia o aspecto objetivo da estabilidade das relações jurídicas, e em princípio da proteção à confiança, quando aludem ao que atenta para o aspecto subjetivo ${ }^{48}$.

\footnotetext{
${ }^{46}$ COUTO E SILVA, Almiro do. Princípios da legalidade da administração pública e da segurança juríd ica no estado de direito contemporâneo. RPGE, Porto Alegre, v. 27, n. 57, p. 11-31, 2004b, p. 14.

47 “Art. 5․ Todos são iguais perante a lei, sem distinção de qualquer natureza, garantindo-se aos brasileiros e aos estrangeiros residentes no País a inviolabilidade do direito à vida, à liberdade, à igualdade, à segurança $\mathrm{e}$ à propriedade, nos termos seguintes:

$[\ldots]$

XXXVI - a lei não prejudicará o dire ito adquirido, o ato ju ríd ico perfe ito e a cois a ju lgada;

$[\ldots] "$.

${ }^{48}$ CANOTILHO, J. J. Go mes. Direito constitucional e teoria da constituição. Coimbra: Almedina, 2000. p. 256, observa que "O homem necessita de segurança para conduzir, planificar e conformar autônoma e responsavelmente a sua vida. Por is so, desde cedo se consideravam os princípios da segurança jurídica e da proteção à confiança como elementos constitutivos do Estado de direito. Es tes dois princípios - segurança jurídica e proteção da confiança - andam estreitamente associados, a ponto de alguns autores considerarem o princípio da proteção de confiança como um subprincípio ou como uma dimensão especifica da segurança jurídica. Em geral, considera-se que na segurança jurídica está conexionada com elementos objetivos da ordem jurídica - garantia de estabilidade jurídica, segurança de orientação e realização do direito enquanto a proteção da confiança se prende mais com as componentes subjectivas da segurança, designadamente a calculabilidade e previsibilidade dos indivíduos em relação aos efeitos jurídicos dos actos". É quase unânime, entretanto, o entendimento de que o "princíp io da proteção da confiança" tem co mo matriz constitucional o "princípio da segurança jurídica", que é subprincípio, ainda que não expresso, do
} 
Trata-se, no caso deste último o princípio, daquele que (a) impõe ao Estado limitações na liberdade de alterar sua conduta e de modificar atos que produziram vantagens para os destinatários, mesmo quando ilegais, ou (b) atribui-lhe consequências patrimoniais por essas alterações, sempre em razão da crença gerada nos beneficiários, nos administrados ou na sociedade em geral de que aqueles atos eram legítimos, tudo fazendo razoavelmente supor que seriam mantidos ${ }^{49}$.

Judith H. Martins-Costa, em parecer sobre Termo de Compromisso de Cessação (TCC) de ajuste entre a empresa consulente e o Conselho Administrativo de Defesa Econômica (Cade), faz, inicialmente, uma distinção entre a boa-fé subjetiva e a boa-fé objetiva para, então, diferenciar esta do princípio da confiança. Segundo a doutrinadora, a boa-fé subjetiva - ou "boa-fé psicológica" - traduz a ideia naturalista da boa-fé que, por antinomia, é conotada à má-fé . $^{50}$.

Diz-se subjetiva a boa-fé compreendida como estado psicológico, estado de consciência caracterizado pela ignorância de se estar a lesar direitos ou interesses alheios. Manifesta-se, também, pela crença justificada na aparência de certa situação ou realidade jurídica ${ }^{51}$.

princípio do Estado de Direito. Nesse sentido, por exemplo, MAURER, Hartmut. Allgemeines Verwaltungsrecht. München: C. H. Beck, 1999. p. 280; Dirk Ehlers, citado por BADURA, Peter et al. Allgemeines Verwaltunsrecht. Berlin: Walter de Gruyter, 1995. p. 109-110; Hans-Uwe Erichsen, citado por BADURA, Peter et al. Allgemeines Verwaltunsrecht, p. 301 e ss.; WOLFF, Hans J.; BASCHOFF, Otto; STOBER, Rolf. Verwaltungsrecht. München: C. H. Beck, 1994. v. 1, p. 350.

${ }^{49}$ COUTO E SILVA, Almiro do. Princípios da legalidade da administração pública e da segurança juríd ica no estado de direito contemporâneo. RPGE, v. 27, n. 57, p. 15.

${ }^{50}$ MARTINS-COSTA, Judith H. Princípio da confiança legítima e princípio da boa-fé objetiva. Termo de Co mpro misso de Cessação (TCC) ajustado como Cade. Critérios de interpretação contratual: os "sistemas de referência extracontratuais" ("circunstâncias do caso") e sua função no quadro semântico da conduta devida. Princípio da unidade ou coerência hermenêutica e "usos do tráfego". Adimplemento contratual. Revista dos Tribunais, v. 852, out. 2006. p. 93.

${ }^{51}$ As diferenciações entre uma e outra boa-fé radicam em que, efetivamente, a boa-fé subjetiva (guter Glaube) é a intenção, decorrerá de um estado de consciência da parte - de estar agindo conforme os padrões de honestidade e fidelidade - por isso não configura uma fonte genérica de obrigações, é casuística e, por seu caráter antes negativo do que positivo, não se pode dizer a priori da existência ou não de responsabilidade (tudo dependerá do caso concreto). Não obstante, a boa-fé objetiva (Treue und Glauben) "não diz respeito ao estado mental subjetivo do agente, mas sim ao seu comportamento em determinada relação ju rídica de cooperação. O seu conteúdo consiste em u m padrão de conduta, variando as suas exigências de acordo como tipo de relação existente entre as partes. A boa-fé objetiva não cria apenas deveres negativos, como o faz a boa-fé subjetiva. Ela cria também deveres positivos, já que exige que as partes tudo façam para que o contrato seja cumprido conforme previsto e para que ambas obtenham o proveito objetivado. Assim, o dever de simples abstenção de prejudicar, característico da boa-fé subjetiva, se transforma na boa-fé objetiva em dever de cooperar" (PEREIRA, Caio Mário da Silva. Instituições de direito civil. Contratos. 11. ed. atual. por Régis Fichtner: Rio de Janeiro. Forense, 2004. v. III, p. 20-21). 
A expressão boa-fé objetiva, por sua vez, designando princípio atuante no domínio dos direitos das obrigações, exprime standard de lisura, correção, probidade, lealdade, honestidade - enfim, o civiliter agere que deve pautar as relações intersubjetivas regradas pelo Direito. Daí a razão pela qual a boa-fé objetiva atue, concomitantemente, como (a) fonte de deveres de conduta (deveres de prestação e deveres de proteção); (b) baliza para a averiguação da licitude no modo de exercício de direitos, vedando, por exemplo, o comportamento contraditório ou desleal; e (c) cânone para a interpretação dos negócios jurídicos, tríplice função hoje perfeitamente discernida nos arts. 113, 187 e 422 do Código Civil (CC) brasileiro $^{52}$. Nas relações obrigacionais (notadamente nas contratuais), o que se exige é uma atitude positiva de cooperação, $\mathrm{e}^{53}$, assim sendo, o princípio é a fonte normativa impositiva de comportamentos cooperativos que se devem pautar por um específico standard ou arquétipo, qual seja, a conduta segundo a boa- fé $^{54}$.

Cita a autora, que, embora ligadas etimologicamente, a boa-fé (bona fides) e a confiança (cum fides) designam realidades funcionais diversas, ainda que conexas.

Enquanto a boa-fé objetiva estaria ligada às mencionadas "relações de cooperação", o princípio da confiança ligar-se-ia, fundamentalmente, com (a) a proteção das expectativas, atuando ainda (b) como justificativa ou explicação para a vinculabilidade dos negócios jurídicos ${ }^{55}$.

Assim, distinguem-se os princípios da boa-fé e da confiança: aquela, a boa-fé, liga-se, primariamente, ao dever geral de cooperação, impondo, para tal fim, pautas de correção, lealdade, probidade e consideração aos interesses legítimos do parceiro (civiliter agere); esta, a confiança, prende-se, primariamente, à geração de expectativas legítimas cuja manutenção pode constituir um dever jurídico (dever de manter a confiança suscitada), assim como sua frustração pode ocasionar responsabilidade por danos

\footnotetext{
52 "Art. 113. Os negócios jurídicos devem ser interpretados conforme a boa-fé e os usos do lugar de sua celebração."; "Art. 187. Também comete ato ilícito o titular de um direito que, ao exercê-lo, excede man ifestamente os limites impostos pelo seu fim econômico ou social, pela boa-fé ou pelos bons costumes."; e "Art. 422. Os contratantes são obrigados a guardar, assim na conclusão do contrato, como em sua execução, os princípios de probidade e boa-fé.”.

${ }^{53}$ BETTI, Emilio. Teoría general de las obligaciones. Revista de Derecho Privado, Madrid, 1969. p. 89.

${ }^{54}$ MARTINS-COSTA, Judith (Org.). A reconstrução do direito privado - refle xo dos princípios, diretrizes e direitos fundamentais constitucionais no direito privado. São Paulo: Revista dos Tribunais, 2002. p. 162.

${ }^{55}$ Idem. Princípio da confiança legítima e princípio da boa-fé objetiva. Termo de Compromisso de Cessação (TCC) ajustado com o Cade. Critérios de interpretação contratual: os "sistemas de referência extracontratuais" ("circunstâncias do caso") e sua função no quadro semântico da conduta devida. Princípio da unidade ou coerência hermenêutica e "usos do tráfego". Adimplemento contratual. Revista dos Tribunais, v. 852 , p. 94.
} 
(responsabilidade pela confiança).

Carneiro da Frada destaca que não interessa em si, para incidência do princípio da confiança, aquilo em que a vítima da violação da regra da boa-fé acreditou. Quando muito, pode-se averiguar se ela devia confiar no comportamento do outro. Mas as expectativas nesse sentido "razoáveis" ou "legítimas" de um sujeito são apenas uma projeção de exigências objetivas do comportamento impostas pela ordem jurídica. Em outras palavras, a tutela das expectativas mediante a regra de boa-fé é apenas reflexa. Releva somente no quadro das exigências de probidade e equilíbrio de conduta que aquela veicula" ${ }^{256}$.

No caso das relações entre particulares e Administração Pública a conjugação dos princípios da boa-fé e da confiança opera em elevado grau, em razão da (a) assimetria de poderes entre os partícipes da relação, marcada por intrínseca verticalidade, e (b) da presunção de legitimidade e de legalidade dos atos administrativos, ambos elementos hábeis à geração de confiança. À lealdade e cooperação como notas características do conceito de boa-fé operante nas relações interprivadas agregam-se com força exponencial os elementos "crença e confiança" como elementos da segurança jurídica.

Dessa forma, no direito público se unem, ora sob a denominação 'boa-fé', ora sob o nome "confiança", os deveres positivos de lealdade e honestidade e os deveres negativos de não frustrar - ou de não suscitar levianamente - as legítimas expectativas do $\operatorname{administrado}^{57}$.

Há, no entanto, outro ponto de conexão. Segundo Canaris, o princípio da proteção da confiança é um princípio ético-jurídico que permanece como pano de fundo, sempre aflorando naqueles casos em que a segurança-garantia, disponibilizada e regulada pela ordem jurídica, fracassa ${ }^{58}$. O princípio da boa-fé também se mantém, em muitos aspectos, de forma subsidiária, manifestando-se quando a equidade se faz necessária. Ambos, princípios éticos - o princípio da proteção à confiança e da boa-fé -, são formas de compensação corretiva da justiça, guardando fluidez e indeterminação em sua

\footnotetext{
56 CARNEIRO DA FRADA, Manuel Antonio de Castro Portugal. Teoria da confiança e responsabilidade civil. Coimbra: Almedina, 2005. p. 454.

${ }^{57}$ MARTINS-COSTA, Judith H. Princípio da confiança legítima e princípio da boa-fé objetiva. Termo de Co mpro mis so de Cessação (TCC) ajustado como Cade. Critérios de interpretação contratual: os "sistemas de referência extracontratuais" ("circunstâncias do caso") e sua função no quadro semântico da conduta devida. Princípio da unidade ou coerência hermenêutica e "usos do tráfego". Adimplemento contratual. Revista dos Tribunais, v. 852, p. 97.

58 CANARIS, Claus-Wilhelm. Die Vertrauenshaftung im Deutschen Privatrecht. München: Verlag C. H. Beck, 1971.p. 491.
} 
materialidade. Revelam-se juntos, nos casos concretos, em que as circunstâncias fáticas tornem imperativa a intervenção para restabelecer o equilíbrio entre as partes, na casuística da jurisprudência. Exatamente nas situações de garantia fraca, a confiança emerge, por necessidade ético-jurídica.

Observa Misabel Derzi, todavia, que o princípio da proteção da confiança tem uma dimensão temporal importante, nem sempre presente em todos os casos de aplicação da boa-fé objetiva. A dimensão temporal encontra, na proteção da confiança, papel decisivo, pois antes da violação da confiança, necessariamente, deverá ter ocorrido ato ou comportamento equivalente. A proteção da confiança envolve uma relação no tempo: o fato da confiança, situação no passado; a confiança que persiste no presente; a confiança que se projeta para o futuro ${ }^{59}$.

Outra questão que diferencia a boa-fé objetiva do princípio da confiança reside no fato de que a irretroatividade e a proteção da confiança são princípios unilateralmente utilizados em favor do contribuinte/cidadão e contra o Estado. Não se aplicam em favor dos órgãos públicos dos Três Poderes. A boa-fé, não obstante, é fonte de deveres e direitos tanto para a Administração tributária como ainda para o contribuinte ${ }^{60}$.

De todo modo, há nitidamente, como observa Carneiro da Frada, o seguinte dilema: o princípio da confiança remete à boa-fé, mas casos difíceis ou de inexistente formulação jurídico-positiva costumam ser remetidos, de novo, da boa-fé à proteção da confiança, em um claro circulus inextricabilis, o que deixa o intérprete-aplicador sem apoio para fundamentar a responsabilidade. E conclui o doutrinador lusitano que não se pode alicerçar a proteção da confiança na boa-fé se, "ao mesmo tempo, se preencher o conteúdo da boa-fé com essa mesma proteção da confiança" $"$.

Segundo Misabel Derzi, de fato há essa zona de interseção entre a confiança e a boa-fé; todavia, mesmo quando se superpõem - boa-fé e confiança -, não coincidem, pois ambos transbordam suas funções, extensão e situações: (a) a proteção da confiança somente se aplica às partes dependentes que não tenham o domínio dos eventos/acontecimentos, mas desfrutem de situação mais frágil em face do outro.

\footnotetext{
${ }^{59}$ DERZI, Misabel Abreu Machado. Modificações da jurisprudência: proteção da confiança, boa-fé objetiva e irretroatividade co mo limitações constitucionais ao poder judicial de tributar, p. XXIII/XXIV.

${ }^{60}$ Ibidem, p. 367.

61 CARNEIRO DA FRADA, Manuel Antonio de Castro Portugal. Teoria da confiança e responsabilidade civil, p. 869, nota 973 .
} 
Exatamente nas situações de garantia fraca, a confiança emerge, por necessidade éticojurídica. Além disso, o princípio da proteção da confiança tem uma dimensão temporal importante, que não é essencial à boa-fé objetiva; (b) o princípio da boa-fé objetiva é fonte de deveres e de obrigações, o que não ocorre com a proteção da confiança. Mas esse ponto peculiar da boa-fé objetiva, no direito público, fica reduzido à legalidade, pois os deveres acessórios e laterais dos contribuintes deverão estar previstos em lei, como manda a Constituição Federal ${ }^{62}$.

Como lembra Mattern ${ }^{63}$, Estado de Direito não é apenas Estado das leis, pois administrar conforme a lei é antes administrar conforme o Direito, razão pela qual a proteção da confiança e a boa-fé são componentes indivisíveis da legalidade do Estado de Direito e da Justiça.

Em obra profunda sobre o tema, explica Roland Kreibich que alguns juristas alemães utilizam a expressão boa-fé como sinônimo de proteção da confiança; outros, como Krieger e Thiel, consideram a proteção da confiança um resultado ou consequência legal da boa-fé; há aqueles ainda, como Mattern, que sobrepõem o princípio da proteção da confiança, para eles mais abrangente, como um "Tatbestand-mãe", ao princípio da boa-fé. Em geral, a expressão boa-fé é utilizada frequentemente para designar as situações individuais, os casos concretos que envolvem a proteção da confiança ${ }^{64}$.

Pondera Kreibich que, no plano abstrato e geral, existem aplicações inerentes ao princípio da proteção da confiança, que não têm relação direta com a boa-fé. São elas: (a) a irretroatividade das leis; (b) a obrigatoriedade do cumprimento de promessas e de prestação de informações; (c) a proteção contra a quebra ou modificação de regras administrativas; (d) a proteção contra a modificação retroativa da jurisprudência; e (e) a garantia da execução de planos governamentais. E, acrescenta o autor, em geral, prevalece a concepção, aliás, dominante nos tribunais superiores da Alemanha, de que o princípio da proteção da confiança deve ser considerado um princípio-mãe, deduzido do Estado de Direito, por meio da segurança ${ }^{65}$.

\footnotetext{
${ }^{62}$ DERZI, Misabel Abreu Machado. Modificações da jurisprudência: proteção da confiança, boa-fé objetiva e irretroatividade co mo limitações constitucionais ao poder judicial de tributar, p. 373/374.

${ }^{63}$ Cf. KREIBICH, Roland. Der Grundsatz von Treu und Glauben im Steuerrecht. Band 12. Heidelberg: C. F. Muller Verlag, 1992.p. 188.

${ }^{64}$ Ibidem, loc. cit..

${ }^{65}$ KREIBICH, Roland. Op. cit., p. 24-25.
} 
Assim, em toda hipótese de boa-fé existe confiança a ser protegida. Isso significa que uma das partes, por meio de seu comportamento objetivo, criou confiança em outra, que, em decorrência da firme crença na duração dessa situação desencadeada pela confiança criada, foi levada a agir ou manifestar-se externamente, fundada em suas legítimas expectativas, que não podem ser frustradas ${ }^{66}$. Mas Kreibich aponta como divergência existente entre o princípio da proteção da confiança e o da boa-fé, o fato de o primeiro, por ser mais abrangente, aplicar-se às situações gerais, abstratas, e àquelas concretas; já o segundo, o princípio da boa-fé, somente alcança uma situação jurídica individual e concreta, ou seja, alcança não as leis e os regulamentos normativos, mas apenas os atos administrativos individuais e as decisões judiciais ${ }^{67}$.

Em conclusão, Kreibich define o princípio da boa-fé como um princípio jurídico em geral (universal), válido para todas as áreas jurídicas, e sem restrições no Direito Tributário, sendo direito não escrito, que exige um comportamento leal e confiável de todos os envolvidos em uma relação jurídica concreta, e que, sendo ainda expressão da ideia da proteção da confiança no Direito Constitucional, mediante a segurança jurídica, decorre do Estado de Direito e da ideia de justiça (que lhe determina o sentido) ${ }^{68}$.

Por derradeiro, é importante destacar que em muitos países a origem do princípio da confiança legítima surgiu como decorrência do Estado de Direito, ao passo que em outros, como Itália, Espanha ${ }^{69}$ e Suíça, o princípio da boa-fé objetiva serviu de caminho pelo qual que se introduziu o princípio da confiança legítima.

Seja como for, do ponto de vista terminológico, no direito alemão e, por influência deste, também no direito comunitário europeu, "segurança jurídica" (Rechtssicherheit) é expressão que em rigor designa a parte objetiva do conceito, ou então simplesmente o "princípio da segurança jurídica", enqua nto a parte subjetiva é identificada como "proteção à confiança" (Vertrauensschutz, no direito germânico) ou "proteção à confiança legítima" (no direito comunitário europeu), ou, respectivamente, "princípio da proteção à confiança" e "princípio da proteção à confiança legítima".

\footnotetext{
${ }^{66}$ DERZI, Misabel Abreu Machado. Modificações da jurisprudência: proteção da confiança, boa-fé objetiva e irretroatividade co mo limitações constitucionais ao poder judicial de tributar, p. 379.

${ }^{67}$ Cf. KREIBICH, Roland. Der Grundsatz von Treu und Glauben im Steuerrecht, p. 59.

${ }^{68}$ Ibidem, p. 198.

${ }^{69}$ COVIELlo, Pedro José Jorge. La protección de la confianza del administrado. Buenos Aires: AbeledoPerrot - Lexis, Nexis, 2004. p. 407.
} 


\section{CAPÍTULO 3}

\section{CERTEZA DO DIREITO E CONFIANÇA LEGÍTIMA}

O princípio da segurança jurídica possui duas faces, uma objetiva, representada pela estabilidade sistêmica e, principalmente, pela certeza do direito, e outra, subjetiva, traduzida no princípio da confiança legítima.

Pode-se dizer que o princípio de certeza do direito é a mais expressiva afirmação do Estado de Direito. Trata-se da segurança jurídica por definição. Na segurança jurídica formal as regras de validade, procedimentos e observância das competências concorrem para a constituição das fontes de produção do direito. A distribuição do poder faz-se de modo horizontal, com base no princípio da separação dos Poderes Legislativo, Executivo e Judiciário, mas também de maneira vertical, pela hierarquia dos órgãos que se integram na estrutura do Estado.

A unidade das normas produzidas por esses órgãos revela um sistema de subordinação hierárquica, segundo critérios de validade estabelecidos na Constituição, como garantia da coerência intrassistêmica. Essa hierarquia dos órgãos produtores de normas e das normas produzidas, por sua vez, promove nos indivíduos um efeito de "orientação" e de certeza sobre como a autoridade pode habilitar-se no exercício da autoridade e como as regras jurídicas são aplicadas em relação à generalidade e abstração das leis constantes.

A certeza ou orientação gera uma expectativa legítima de confiabilidade no sistema jurídico, pela ação dos órgãos de produção de normas, mas também sobre direitos assegurados, como se verifica nos casos de manutenção de benefícios físcais com prazo certo e outros. Enfim, ao longo de todo o ordenamento a função "certeza" cumpre papel fundamental em face dos destinatários da ordem jurídica e das condutas normatizadas.

No direito tributário a previsibilidade tem importância capital para a vida dos contribuintes ${ }^{70}$, como certeza de orientação para que possam planejar suas atividades e atos 70 A esse propósito, anota Paulo de Barros Carvalho que, "Substanciando a necessidade premente da
segurança do indivíduo, o sistema empírico do direito elege a certeza como postulado indispensável para
convivência social organizada" (CARVALHO, Paulo de Barros. Curso de direito tributário. 21. ed. São 
patrimoniais cientes das repercussões fiscais de suas condutas. A previsibilidade é a segurança jurídica sobre o "futuro", resguarda o contribuinte pela prevenção de riscos, sanções e conflitos. Diante disso, a segurança jurídica da atualidade deixa de ser fortemente centrada nos efeitos sobre o passado para tornar-se segurança de expectativas do porvir, da organização do futuro.

Essa mudança dá-se porque o curso das ações dos contribuintes depende de pautas de previsibilidade das leis. No tempo presente, pela segurança jurídica, exige-se determinação de conceitos, objetividade e clareza das leis tributárias, pois dificuldades na definição das condutas podem induzir contribuintes a erros ou ao descumprimento da legislação, o que lhes poderá render sanções ou até mesmo a privação da liberdade ${ }^{71}$.

Exatamente por esse motivo é que, para controlar a complexidade, assegurar a clareza e a preservação de expectativas legítimas, o Sistema Constitucional Tributário deve diligenciar para reduzir, permanentemente, a indeterminação de suas regras, mediante ações e procedimentos que confiram certeza aos conteúdos das competências, dos direitos e garantias inerentes às medidas de justiça do sistema tributário. Esse cuidado permitirá que se obtenha estabilidade na aplicação das leis tributárias, a partir de uma construção de sentido orientada pelo fim sistêmico da segurança jurídica ${ }^{72}$.

A continuidade do ordenamento é a mais evidente tradução da estabilidade e da previsibilidade do sistema. Não basta para o princípio de segurança jurídica o controle sobre a produção normativa ou preservação de efeitos de atos passados. As exigências de consistência e de coerência das normas são igualmente relevantes. A consistência preserva o sistema de contradições de decisões, enquanto a coerência vale por favorecer a formação de expectativas seguras no sistema jurídico. Não significa que a incerteza possa ser banida, mas que seja ao menos controlável.

A previsibilidade de comportamento e o controle de expectativas são a marca e o sentido do direito na sociedade; por isso a certeza do direito é uma garantia contra o arbítrio dos intérpretes, mas também um meio de garantir a "orientação" das condutas, para

\footnotetext{
Paulo: Saraiva, 2009. p. 145).

71 TORRES, Heleno Taveira. Direito constitucional tributário e segurança jurídica: metódica da segurança jurídica do sis tema constitucional tributário, p. 206/207.

72 Ibide m, p. 209.
} 
que todos saibam previamente quais são os seus direitos e deveres e os cumpram na maior medida possível ${ }^{73}$.

A certeza do direito gera, portanto, uma segurança de orientação. E para que esta possa ser eficiente, devem-se prover os atos normativos de clareza, precisão e congruência, e, assim, permitam uma correta aplicação das normas jurídicas ${ }^{74}$. Em razão disso, evitar conflitos, afastar a arbitrariedade e favorecer a adequação de condutas ao direito são as finalidades mais relevantes do princípio de certeza do direito.

A certeza do direito, por consequência, é um conteúdo expressivo do princípio da segurança jurídica, certamente sua porção mais significativa e que, em termos objetivos, corresponde à prévia determinação de todos os elementos necessários à qualificação dos elementos fáticos e subjetivos necessários para a constituição de qualquer obrigação tributária. Reduz-se, com isso, o campo de indeterminação dos conceitos (lex certa, stricta e completa), tornando-se maior a garantia de segurança jurídica ${ }^{75}$.

A questão da tentativa de diminuir a complexidade do sistema e de tornar os conceitos mais determinados está ligada diretamente ao que se chama de "cognoscibilidade do direito".

A ideia em comento estipula que o sistema jurídico de um Estado Democrático deve garantir o amplo acesso ao conhecimento do direito porque suas regras são heterônomas, provenientes das mais diversas fontes, e o seu desconhecimento é inescusável ${ }^{76}$.

É tão relevante a dignidade do acesso por inteligibilidade das leis que, no Brasil, essa matéria encontra-se positivada na "lei sobre leis". A Lei Complementar (LC) no 95/1998 estatui, no art. 11, essa exigência de clareza e precisão na redação dos textos das normas (inteligibilidade).

Para a obtenção de clareza, entre outros, a LC nº 95/1998 determina que a lei deve usar as palavras e as expressões em seu sentido comum, salvo quando a norma versar sobre assunto técnico, hipótese em que se empregará a nomenclatura própria da área em que

\footnotetext{
73 TORRES, Heleno Taveira. Direito constitucional tributário e segurança jurídica: metódica da segurança jurídica do sistema constitucional tributário, p. 272/273.

74 GARCÍA MA YNEZ, Eduardo. Filosofía del derecho. 16. ed. Ciudad de México: Porrúa, 2007. p. 478.

75 TORRES, Heleno Taveira. Op. cit., p. 273/274.

${ }^{76}$ Ibide m, p. 249.
} 
esteja legislando; e, para a obtenção de precisão, exige que a linguagem, técnica ou comum, seja articulada de modo a ensejar a perfeita compreensão do objetivo da lei e a permitir que seu texto evidencie com clareza o conteúdo e o alcance que legislador pretende dar à norma ${ }^{77}$.

Tudo isso porque a cada dia torna-se menos provável o desgastado adágio Nemo legem ignorare consetur, ou seja, a arguição de descumprimento por ignorância da lei. $\mathrm{O}$ excesso de leis conduz à complexidade do sistema tributário, com ampliação de dificuldades de acesso de toda espécie. A observância da legislação tributária assumiu proporções de complexidade e de inacessibilidade cognitiva de tal ordem que muitos contribuintes não conseguem cumprir todas as exigências fiscais sem que suportem custos vultosos de assessoria jurídica e contábil para acompanhamento das modificações e dificuldades hermenêuticas de todo tipo ${ }^{78}$.

A inflação legislativa, por si só, prejudica o acesso intelectual ao direito e, com isso, concorre para o aprofundamento da insegurança jurídica. Chega a ser redundante dizer dos problemas daí insurgentes. Ressalte-se, no entanto, que, de plano, afeta gravemente a igualdade entre os destinatários. Basta pensar nos elevados custos para manter a gestão da legislação e do seu cumprimento e da diferença de reação ao cumprimento das obrigações tributárias entre aqueles que dispõem de um corpo técnico dedicado a essas tormentas legislativas e os que são auxiliados por profissionais esporádicos e pouco qualificados.

Contra essas práticas normativas, a LC nº 95/1998, que é a lei geral em matéria legislativa (art. 59, parágrafo único, da $\mathrm{CF}$ ), no art. 7ํㅜ , prevê que cada lei tratará de um único objeto (a), a lei não conterá matéria estranha ao seu objeto ou a este não vinculada por afinidade, pertinência ou conexão (b); o âmbito de aplicação da lei será estabelecido de forma tão específica quanto possibilite o conhecimento técnico ou científico da área respectiva (c); e o mesmo assunto não poderá ser disciplinado por mais de uma lei, exceto quando a subsequente se destine a complementar lei considerada básica, vinculando-se a esta por remissão expressa (d).

\footnotetext{
77 TORRES, Heleno Taveira. Direito constitucional tributário e segurança jurídica: metódica da segurança jurídica do sistema constitucional tributário, p. 252.

${ }^{78}$ Ibide m, p. 255.
} 
Tudo isso para garantir acessibilidade, mas, principalmente, estabilidade da estrutura normativa. Falta-lhe, porém, efetividade e observância pelos parlamentares do federalismo tributário brasileiro ${ }^{79}$.

Viver sob o império da lei é ter direito à segurança jurídica e especialmente a certeza do direito e eficiência administrativa. Atenta, pois, contra a legalidade, a moralidade e a eficiência, princípios fundamentais para a Administração Pública (art. 37 da $\mathrm{CF}$ ), o uso de atos normativos administrativos para inovações à legalidade e, tanto pior, para retroceder, a pretexto de serem interpretativos, eficácia que somente às "leis" vê-se atribuída, pelo art. 106, inciso I, do $\mathrm{CTN}^{80}$.

A certeza do direito, como expressão de segurança jurídica, decorre da expectativa de previsibilidade sobre as condutas do Estado na regular positivação do direito. Trata-se, assim, do aspecto objetivo da segurança jurídica, ao passo que ao princípio da confiança legítima cabe a proteção da segurança jurídica sob o enfoque subjetivo ${ }^{81}$.

\footnotetext{
${ }^{79}$ TORRES, Heleno Taveira. Direito constitucional tributário e segurança jurídica: metódica da segurança jurídica do sistema constitucional tributário, p. 263/264.

${ }^{80}$ Ibide m, p. 268.

${ }^{81}$ Ibidem, p. 269.
} 


\section{CAPÍTULO 4}

\section{PRINCÍPIO DA CONFIANÇA LEGÍTIMA}

O princípio da confiança legítima pode ser justificado como decorrência de inúmeros princípios ${ }^{82}$. Afirma-se que ele seria derivado dos princípios da liberdade e da propriedade, já que pela aplicação do princípio da confiança seriam protegidos os investimentos de confiança, ou seja, as disposições (liberdade) do patrimônio (propriedade) em um ou outro sentido em razão do ato administrativo que depois se revelou ilegal.

Há também quem sustente que o princípio da confiança legítima decorreria do princípio da moralidade, traduzido na impossibilidade de comportamentos contraditórios pela Administração Pública.

Nos tópicos seguintes, o princípio da confiança legítima será analisado com base na irretroatividade e também como forma de superação do princípio da legalidade como valor absoluto no ordenamento jurídico.

\subsection{Da Irretroatividade como Mecanismo Justificador do Princípio da Confiança Legítima}

\subsubsection{O Sistema de Luhmann}

Niklas Luhmann analisou a confiança legítima na formação do sistema jurídico, assunto a ser examinado nos itens a seguir.

\footnotetext{
${ }^{82}$ Heiki Pohl pondera: “a relação entre os princípios da segurança jurídica e a proteção da confiança e sua dedução dogmática não foram totalmente esclarecidas. Elas se encontram numa sequência de dedução: princípio do Es tado de Direito - segurança jurídica - proteção da confiança, ou são dedutíveis, um ao lado do outro do princípio do Estado de Direito e, em parte, a expressão segurança jurídica é evitada em favor da proteção da confiança. O princípio da proteção da confiança é obtido também dos direitos fundamentais, do princípio do Estado social ou de um grupo de princípios” (POHL, Heiki. Rechtsprechungänderung und Rückanknüpfung. Berlin: Duncker \& Humboldt, p. 173. Tradução não autorizada pelo autor de Kirsten Lage, 2005. p. 321-323).
} 


\subsubsection{O Papel da Confiança na Formação do Sistema}

A complexidade das sociedades de risco contemporâneas, tomada como problema central por Niklas Luhmann, é abordada por meio de quatro técnicas usadas para sua redução, cada qual se relacionando uma com a outra.

As técnicas redutoras da complexidade do mundo são: (a) a linguagem, que pressupõe a representação e a autoconsciência reflexiva, permitindo a formação de generalizações e seletividade; (b) a concepção dos sistemas, assim entendida a forma de ordenação unitária, que necessariamente se utiliza de abstração e universalidade, sobretudo guiadas pela coerência dogmática; (c) o tempo (autêntico); e (d) a confiança, que viabiliza a vida e as ações.

Segundo explica o autor:

“A questão da complexidade define o problema fundamental, a partir do qual a confiança pode ser analisada funcionalmente e comparada com outros mecanismos sociais, funcionalmente equivalentes. Onde há confiança há aumento de possibilidades para a experiência e a ação; há possibilidade de um aumento da complexidade do sistema social; e também há um aumento do número de possibilidades que podem reconciliar-se com sua estrutura, porque a confiança constrói uma forma mais efetiva de redução da complexidade" ${ }^{83}$.

Cabe destacar que o próprio tempo também está em relação problemática com a confiança e ele, por si, pode ser um instrumento redutor de complexidade. Isso porque, “mostrar confiança é antecipar o futuro. É comportar-se como se o futuro fosse certo. Poder-se-ia dizer que, através da confiança, o tempo se invalida ou ao menos se invalidam as diferenças de tempo" $" 84$.

De fato, ao analisar a relação entre tempo e confiança, Nik las Luhmann diferencia o tempo como fluxo, unidimensional, para trazer as noções de duração por oposição à de variação, ou a noção de estado em contraste com a de evento/acontecimento. Sem essas noções, não há possibilidade de se enveredar na questão da confiança. É que as impressões

\footnotetext{
${ }^{83}$ LUHMANN, Niklas. Confianza. Trad. A mada Flores. Santiago: Anthropos Universidad IberoA mericana. 1996. p. 14.

${ }^{84}$ Ibidem, p. 15.
} 
cambiantes, que estão em tudo e em toda parte, até mesmo nas pessoas, são possíveis por meio da experiência humana de duração, oposta à de variação. Com essa primeira noção, constrói-se, intersubjetivamente, o tempo objetivo, como medida do relógio, um contínuo de pontos, entre os dois "agoras", igual para todos os homens, neutro. O tempo objetivo inclui o constante e o que muda.

Mas para lá dessa noção objetiva, pode-se identificar um estado constante, que persiste, apesar da variação dos pontos, apesar da continuidade dos "agoras" fluindo. A duração, nesse sentido, diz Luhmann nada mais é do que o presente continuamente atual, com o futuro sempre em perspectiva e o passado como o "agora que não mais se dá". Os estados são identificados somente na medida em que se dão no presente.

Ao relacionar a confiança e o tempo, o autor explica que:

“[...] o problema da confiança é que o futuro contém muito mais possibilidades do que aquelas que poderiam atualizar-se no presente e do presente transferir-se ao passado. A incerteza é elementar: nem todos os fatores podem converter-se em presente e daqui em passado. $\mathrm{O}$ futuro coloca uma carga excessiva na habilidade do homem para representar coisas para si mesmo. Portanto a confiança deve reduzir o futuro de modo que se iguale com o presente, isto é, reduza a complexidade" ${ }^{85}$.

Luhmann prevê, portanto, para a formação da confiança, considerando-se a problemática da complexidade, à luz do tempo, a noção elementar da segurança do estado - a partir do presente, como noção de constância relativa, apesar da variação contínua; a simplificação do mundo, por meio da redução da variação infinita; o futuro em prospecção, mediante sua antecipação e redução das alternativas inumeráveis às alternativas já conhecidas do presente. "A dimensão temporal é, portanto, como dimensão social, uma interpretação do mundo", em termos de extrema complexidade.

Por isso o próprio tempo - tomado na acepção de tempo social, autêntico - é um redutor de complexidade. "A confiança é requerida para a redução de um futuro, caracterizado por uma complexidade mais ou menos indeterminada" $" 86$.

Assim, a confiança se revela necessária para que o homem possa lidar com a extrema complexidade do mundo, despertando a segurança do estado (no presente), que

${ }^{85}$ LUHMANN, Niklas. Confianza, p. 21.

${ }^{86}$ Ibidem, p. 26. 
reduz a complexidade e se projeta para o futuro. As alternativas/eventos, em princípio infinitos e virtuais do futuro, são equiparadas às alternativas selecionadas no presente.

A confiança, desse modo, supõe três características básicas: (a) a permanência dos estados, de modo que se igualem presentes e futuros; (b) a simplificação, por meio da redução da complexidade e das infinitas possibilidades variáveis; e (c) a antecipação do futuro, pela projeção que se dá no presente, para tempos que virão.

O autor, no entanto, faz uma advertência para o fato de que onde não se coloca a possibilidade de variação incontrolada, não se põe a questão da confiança. Em outras palavras, onde há supremacia sobre os eventos/acontecimentos, a confiança não é necessária $^{87}$.

Essa constatação é importante na esfera do princípio da confiança legítima porque, na linha de Luhmann, a confiança e a proteção da confiança não se colocam do ponto de vista do Estado, como ente soberano. Isso porque, nas obrigações ex lege, o Estado tem supremacia sobre os eventos/acontecimentos que ele mesmo provoca, ou seja, as leis, as decisões administrativas e as decisões judiciais na modelação e cobrança de tributos ${ }^{88}$.

\subsubsection{Da Simplicidade da Confiança Familiar à Evolução para a Confiança Sistêmica}

Em mundos familiares o passado prevalece sobre o presente e o futuro. O recurso ao passado pode ajudar a compreender e a simplificar a vida. Em verdade, utiliza-se de outros instrumentos técnicos como da História, para exclusão da ação inesperada. Confiase somente naquilo que é conhecido, isto é, que tem conosco história. A familiaridade e a confiança são, portanto, formas complementares para absorver a complexidade.

Todavia, na medida em que as sociedades se tornam mais complexas, a familiaridade - por parentesco ou por experiência fática - perde seu caráter prosaico; então a História deixa de ser a memória das coisas experimentadas para tornar-se uma estrutura

\footnotetext{
${ }^{87}$ LUHMANN, Niklas. Confianza, p. 26.

${ }^{88}$ DERZI, Misabel Abreu Machado. Modificações da jurisprudência: proteção da confiança, boa-fé objetiva e irretroatividade co mo limitações constitucionais ao poder judicial de tributar, p. 328.
} 
predeterminada, que é a base para a confiança. Na fase ainda familiar, a confiança é antes interpessoal e serve, sobretudo, para superar a incerteza em relação ao comportamento das outras pessoas. À medida que cresce a complexidade, a familiaridade se reduz - embora não seja eliminada -, nascendo como resultado a confiança no sistema "que implica renunciar, como um risco consciente, a alguma possibilidade de maior informação e ao contínuo controle dos resultados" $" 89$.

A confiança não significa, assim, mera esperança; ela implica a expectativa confiável, que interfere diretamente na decisão tomada pela pessoa que confia. Ademais, a confiança projeta a expectativa para além dos fatos passados, para além da experiência específica, das informações obtidas, e generaliza para outros casos similares (desconhecidos). O processo de generalização de expectativas, diz Luhmann, possui três aspectos: (a) indica o deslocamento parcial do "externo" (experiências concretas) para o "interno"; (b) indica um processo de aprendizagem, que se institucionaliza; e (c) suporta uma resolução simbólica dos resultados do ambiente.

O processo de confiança processa a experiência, de forma seletiva, ao "internalizar" e, com isso, pensar, selecionar e generalizar. A generalização é compulsivamente perseguida, e, por meio dela, simplifica-se o ambiente ${ }^{90}$.

Consoante ensina Luhmann, a confiança é uma atitude que não é nem objetiva, nem subjetiva; ela "não é transferível a outros objetos nem a outras pessoas que confiam" 91 .

Por ser o mundo objetivo mais complexo do que qualquer sistema, a confiança é necessidade pessoal, interpessoal e sistêmica. Como o sistema é incapaz de captar inteiramente o real, ele interpreta o mundo seletivamente, rebaixa a informação que possui e, com isso, a complexidade. A confiança sistêmica é uma ilusão, ou seja, ela supõe a falta de informações. Quem dispõe de informações muito completas e consistentes de um fato não precisa confiar; no entanto, quando não se pode esgotar as informações, o risco é inerente ao processo. O sistema funciona, então, com confiança.

Os requisitos para a outorga da confiança são dois. O primeiro diz respeito à familiaridade ou à informação prévia. A deficiência informativa não pode ser radical. Evidente que confiança supõe uma informação prévia - mesmo deficiente - que reduz o

\footnotetext{
${ }^{89}$ LUHMANN, Niklas. Confianza, p. 33-37.

${ }^{90}$ Ibidem, p. 38-51.

91 Ibidem, p. 47.
} 
risco, mas não o elimina. Nas sociedades simples, a familiaridade - como experiência fática pessoal - é fator de supressão da necessidade de outras informações institucionais, mas à medida que se passa aos modelos mais complexos, do "externo", para o "interno", e para a aprendizagem, a reflexão afasta o homem do objeto observado, reduzindo a familiaridade fática. Então a confiança deverá superar a desinformação - em grau relativamente mais elevado.

O segundo requisito para se outorgar confiança, de acordo com Luhmann, são as estruturas motivadoras, como as leis, que permitem o desenvolvimento da confiança, porque estabilizam as expectativas, tornando-as sancionáveis.

Mecanismos de comunicação como o dinheiro, a verdade - ou a sua busca, a inspirar a mídia e a tecnologia - e a organização política e administrativa pressupõem a confiança. Confia-se na verdade do sistema - do conhecimento, das informações, da notícia midiática - e não propriamente nas pessoas. E a dimensão do tempo, assevera o doutrinador em comento,

\footnotetext{
“[...] é especialmente relevante para todos esses mecanismos generalizados, e ao mesmo tempo, ele explica por que a confiança é um requisito prévio para eles. Se um sistema tem dinheiro efetivo, se tem poder, pode postergar suas decisões e, além disso, assegurá-las dentro de um contexto dado de possíveis escolhas. O sistema pode formar largas cadeias que conectem os acontecimentos seletivos, sem ser capaz de conhecer ou especificar de antemão as situações que, com eles, se coordenam" ${ }^{92}$.
}

A confiança pode, assim, expandir os horizontes de tempo de um sistema.

A formação da confiança sistêmica é um processo em que os ingredientes que o compõem parecem apoiar-se uns nos outros: a necessidade e o método de aprendizagem; a troca parcial das áreas do externo pelo interno; e novamente a referência ao ambiente com o propósito de controlar "simbolicamente" o objeto da confiança. A confiança sistêmica é tão importante, condição ela mesma dos mecanismos de comunicação essenciais, que “dificilmente se faz um assunto aberto à discussão pública e, assim mesmo, o fato de que seja algo latente ajuda a manter a sua integridade" 93 .

\footnotetext{
${ }^{92}$ LUHMANN, Niklas. Confianza, p. 97.

93 Ibidem, p. 99.
} 
Ao mostrar que a confiança no sistema é nele absorvida, pelo menos em parte, já que se mantém latente, Luhmann demonstra que se trata de uma confiança sistêmica fundamentalmente diferente da experiência ingênua da familiaridade com o mundo cotidiano.

De acordo com esse autor, "na confiança no sistema, está-se continuamente consciente de que tudo o que se realiza é um produto, que cada ação foi decidida depois de ser comparada com outras possibilidades".

Essa confiança, no entanto, torna-se reflexiva. Em lugar apenas de uma confiança espontânea, tem-se uma confiança "percebida". Examinam-se continuamente os pressupos tos da confiança - e estudos contemporâneos, cada vez mais crescentes, são disso um exemplo, a justificação da confiança e seus limites, de tal forma que, caso se conclua que ela é injustificável, substitui-se a confiança por uma busca de mais informação, e, se o controle simbólico dos resultados no ambiente for abalado, então, parte-se para novas regras, porque os símbolos pressupõem cooperação, além da aparência que é fabricada. Toda aparência criada pode ser destruída. Conclui Luhmann que,

\begin{abstract}
"Em todos esses casos, é uma marca características da confiança estabilizadora, que ela incorpore um elemento de reflexividade. A confiança não está interessada em conhecer a verdade essencial acerca de um assunto, mas antes no êxito da redução da complexidade, no fato de que a aceitação do risco implicado chega a ser uma força motivadora, que produz mais testemunhas. A confiança está relacionada consigo mesma, na medida em que é necessário assegurar sua capacidade de aumentar o cumprimento de sua função. E dessa forma, pode conseguir mais, ou seja, absorver mais incerteza com menos risco" ${ }^{\prime 94}$.
\end{abstract}

Mas todo sistema abriga também o oposto da confiança. A confiança supõe a expansão da confiança, porque, igualmente, latente no sistema, alastra-se a desconfiança. A predominância da confiança sobre a desconfiança supõe testemunhas, ou seja, supõe que os outros também confiem.

"Parece antes que a familiaridade com o dinheiro, o poder e a verdade é apreendida como uma conduta e que, tipicamente, a reflexividade desse mecanismo fique latente, assim como também o seu caráter altamente

${ }^{94}$ LUHMANN, Niklas. Confianza, p. 120. 
arriscado. Tal estado latente pode fazer com que a criação da confiança seja mais simples e atuar como uma salvaguarda contra tremores incontroláveis - o que aconteceria se cada um, de repente, quisesse trocar em moeda todo seu dinheiro, ou se andasse armado nas ruas? [...] a base racional da confiança depositada na confiança de outras pessoas." ${ }^{95}$

A reflexividade da confiança sistêmica torna a confiança um valor, de tal modo que a confiança de uns supõe a confiança de outros, mas sob relativo controle, porque a confiança sistêmica é, em grande parte, "percebida", razão pela qual a desconfiança latente pode transparecer como equivalente funcional da confiança, ou seja, como redutor adicional de complexidade.

\subsubsection{Da Confiança à Desconfiança}

Se é verdade que a confiança reduz a complexidade da vida, por meio da aceitação do risco, a desconfiança não é apenas o oposto da confiança, mas ainda seu equivalente funcional porque ela igualmente simplifica e, às vezes, de maneira radical.

Quem rejeita a outorga de confiança, é verdade, restaura a complexidade original que poderia ter sido reduzida pela confiança -, mas se volta para estratégias funcionalmente equivalentes: combate, mobilização de reservas e, mesmo, renúncia às necessidades que não podem mais ser satisfeitas.

"Consequentemente a desconfiança também logra a simplificação, não raramente uma simplificação drástica. Uma pessoa que desconfia necessita de muito mais informação, mas ao mesmo tempo limita a informação àquilo que ela sente seguramente que pode confiar. Faz-se mais dependente com relação a menos informação"96.

O sistema jurídico também absorve desconfiança, que permanece latente - uma série de medidas é adotada sem o claro reconhecimento da desconfiança. Sem dúvida o jogo dos delitos e das penas tem a função de estabilizar expectativas, mas também

${ }^{95}$ LUHMANN, Niklas. Confianza, p. 121.

${ }^{96}$ Ibidem, p. 124. 
sinalizam desconfiança sistêmica. No Direito Financeiro, as técnicas de controle das Finanças Públicas, como legalidade orçamentária, execução do orçamento e prestação anual de contas, absorvem desconfiança, justificada pela experiência histórica do passado. No Direito Tributário, a desconfiança manifesta-se, frequentemente implícita, em regras de controle, por meio da imposição de uma série de deveres acessórios, informações, registros contábeis e declarações impostas aos contribuintes; às vezes, em regras de presunção, simplificação e pautas de valores; mas chega a seu ponto mais elevado em institutos como a substituição tributária progressiva, em que se cria a obrigação de pagar o tributo antes mesmo da ocorrência do fato jurídico que lhe dará origem. Por todo o sistema perpassam regras antissonegação ou antifraude. De fato, a simplificação que a desconfiança obtém pode ser mais drástica e a ela corresponder uma renúncia a informações mais aprofundadas ou a valores, que são sacrificados, pela recusa da confiança ${ }^{97}$.

Enfim, ao lado das técnicas usadas para a redução do risco, crescente nas sociedades contemporâneas - a linguagem, com a formação de generalizações e seletividade conceituais; os sistemas que necessariamente se utilizam da abstração e da generalidade; e o tempo -, a confiança atua em relação dependente com todas elas, construindo uma forma mais efetiva de redução da complexidade. Ela antecipa o futuro, estabilizando as relações, pois pressupõe que um estado (presente) permaneça, igualandose ao futuro, por meio da redução das infinitas possibilidades virtuais dos "agoras" supervenientes àquelas conhecidas e já selecionadas no "agora" do presente.

Como nas sociedades complexas é necessário renunciar, pelo menos em termos parciais, aos meios utilizados, primitiva e primariamente, para outorgar confiança redução drástica das informações e do controle pessoal e concreto dos resultados - faz-se agudo o processo de generalização, com que se passa dos casos conhecidos (busca do passado) para outros casos similares prováveis, desconhecidos e futuros. Esse é um processo de "internalização", de aprendizagem e de controle meramente "simbólico" dos resultados. A confiança será sistêmica, difusa e latente.

Destacam-se dos textos de Luhmann as seguintes lições, como observa Misabel $\operatorname{Derzi}^{98}$ :

\footnotetext{
${ }^{97}$ DERZI, Misabel Abreu Machado. Modificações da jurisprudência: proteção da confiança, boa-fé objetiva e irretroatividade co mo limitações constitucionais ao poder judicial de tributar, p. 334-336.

${ }^{98}$ Ibidem, p. 337/338.
} 
(a) A confiança não significa mera esperança; ela implica a expectativa confiável, que interfere diretamente na decisão tomada por aquele que confia.

(b) A confiança supõe certa exposição ao risco, certa relação de dependência daquele que confia. Onde há supremacia sobre os eventos/acontecimentos, a confiança não é necessária, nem a sua proteção. Nesse ponto iniciam-se as razões pelas quais, nas relações tributárias, o Estado não ocupa a posição daquele que confia, e que, por isso, mereça proteção, mas a ele poderá ser imputada a responsabilidade pela confiança gerada. O Estado é o detentor da supremacia sobre os eventos/acontecimentos, pois fabrica as leis, promove as cobranças de tributos e, ao mesmo tempo, julga os conflitos, jamais o contribuinte - pelo menos diretamente. As leis são resultado do processo democrático, em que o interesse de todos deve ou deveria ser considerado, ou, pelo menos, posto no espaço público. Na realidade pública brasileira, no entanto, a supremacia sobre os eventos/acontecimentos é feita de forma aguda: as iniciativas das leis tributárias, altamente técnicas e inacessíveis em sua inteligência ao contribuinte médio, as medidas provisórias, bastante férteis em matéria tributária e elaboradas no silêncio palaciano dos governos, as maiorias mantidas no Congresso por meio das barganhas de cargos e favores constantemente noticiados pela mídia, tudo isso assegura que, efetivamente, essa dependência do contribuinte às ações do Estado e a supremacia estatal sobre os acontecimentos são fatos irrefutáveis.

(c) Dentre as precondições para se outorgar confiança - a deficiência informativa (em que o risco existente ainda permanece); as estruturas motivadoras e impulsivas do processo de se gerar confiança, como as leis e normas em geral; e os mecanismos de comunicação -, a lei será apenas uma delas, por isso mesmo a legalidade não esgota a riqueza e a extensão da confiança, que a transborda em seu estado latente.

(d) A confiança expande os tempos de um sistema, permite o resgate do passado e a antecipação do futuro.

(e) A reflexividade é fator de aumento da confiança e, pois, da red ução do risco e da complexidade, daí resultando a confiança como valor. Com isso, pode-se dizer que o sistema convive com confiança latente e confiança, em grande parte, "percebida".

(f) A desconfiança, sempre latente como a confiança, também é poderosa redutora de complexidade, mas, em razão de sua capacidade destrutiva, tem necessariamente de ser combatida e limitada. 


\subsubsection{A Solução de Conflitos no Interior do Sistema}

Em uma sociedade dinâmica e complexa, as fontes de produção das normas gerais, das expectativas normativas tradicionais - como as leis - são cada vez mais solicitadas, pois conflitos novos e de natureza variada provocam novas soluções; com isso, alimentam o sistema de novas informações e orientações que servirão de subsídios para a decisão de conflitos.

O sistema jurídico, cada vez mais, é um conjunto altamente complexo - porém, mais reduzido do que a realidade social - de solução de conflitos. No centro do sistema está, como quer Luhmann, o Poder Judiciário, que deve traduzir a função atribuída ao Direito nas sociedades contemporâneas ${ }^{99}$.

Segundo o autor, do Direito se exige o desenvolvimento compreensivo da generalização e da estabilização das expectativas de comportamento. No contexto das mudanças contínuas da realidade e de sua alta complexidade, os riscos são tão elevados que o papel do Direito é insubstituível e funcionalmente destinado a generalizar para estabilizar as "expectativas normativas de comportamento"100. Essas funções vêm colhidas e isoladas sob um ponto de vista específico, em particular da perspectiva da regulação dos conflitos, cumprida mediante um sistema para a decisão dos conflitos mesmo inserida $a$ posteriori.

Ao relacionar a dogmática jurídica com o sistema, Luhmann esclarece que ela não é o próprio sistema, mas tão somente a sua metalinguagem. Em relação à complexidade cada vez maior da sociedade, o sistema jurídico e a dogmática representam uma redução daquela complexidade da realidade social. A dogmática jurídica exerce assim uma espécie de controle sobre a aplicação do Direito e é norte para as decisões a serem tomadas. Para esse doutrinador, os conceitos, a teoria, o conhecimento da dogmática não são o sistema do Direito, mas guiam tal sistema; portanto, o sistema é uma construção que se destina a possibilitar a vida, por meio da redução da complexidade do mundo. Um dos apoios de que se vale o sistema encontra-se na dogmática jurídica.

\footnotetext{
99 DERZI, Misabel Abreu Machado. Modificações da jurisprudência: proteção da confiança, boa-fé objetiva e irretroatividade co mo limitações constitucionais ao poder judicial de tributar, p. 13.

100 Cf. LUHMANN, Niklas. Sistema giuridico e dogmatica giuridica. Trad. Alberto Febbrajo. Bologna: Il Mulino, 1978. p. 59.
} 
A positivação crescente do Direito resulta da necessidade de o sistema se apresentar como um programa de solução de conflitos. Nele,

"[...] a atividade de decisão coloca os fatos e a consequência jurídica numa relação do tipo 'se... então'; ou seja, se forem cumpridas determinadas condições, segue-se uma determinada decisão, como uma efetiva programação condic ional. Esta estrutura possibilita a quem decide a exclusão da responsabilidade de consequências imprevistas, uma vez que a validade da norma esteja garantida; mas permite ainda a algor itmização e, portanto, a automatização do processo de decisão.

A escolha das consequências, em contrapartida, realiza-a o legislador, o qual já não age segundo programas condicionais, mas, antes, segundo consoante programas orientados para objetivos, como, por exemplo, a garantia da autonomia informacional dos cidadãos. Também ele dispõe de possibilidade de autocorreção." ${ }^{101}$

Assim estão postas as diferenças essenciais que configuram o sistema de Luhmann.

\subsubsection{O Te mpo}

Vê-se que o legislador traça os programas-metas, com objetivos a alcançar, pensando nas consequências de suas decisões até o fim. Ele decide entre os interesses postos em questão. Já o operador do Direito, como o juiz - e bem assim o Administrador Público -, é posto em face dessa seleção prévia, olhando para o input do sistema, onde se situam as fontes de produção legais. Ele não trabalha diretamente com interesses políticos, econômicos, sociais, morais etc. -, mas com conceitos, ordenações e classificações em que se converteram aqueles interesses, fechando-se operacionalmente o sistema às intervenções diretas do ambiente externo ${ }^{102}$.

Daí dizer-se que o sistema jurídico é pensado para uma série de decisões inseridas $a$ posteriori, em especial para as sentenças. A criação de expectativas normativas permite ao

101 Cf. BULLESBACH, Alfred. Princípios de teoria dos sistemas. In: KAUFMANN, A.; HASSEMER, W. Introdução à filosofia do direito e à teoria do direito contemporâneas. Trad. Manuel Seca de Oliveira. Lisboa: Fundação Calouste Gu lbenkian, 2002. p. 409.

102 DERZI, Misabel Abreu Machado. Modificações da jurisprudência: proteção da confiança, boa-fé objetiva e irretroatividade co mo limitações constitucionais ao poder judicial de tributar, p. 20-22. 
sistema jurídico - que parte dos confins do input - mover-se em horizontes mais amplos, por meio das antecipações dos comportamentos futuros, quer para evitar conflitos, quer para solucioná-los.

O ofício da lei, portanto, é regrar o futuro; o passado não está mais sob o seu poder. Essa, aliás, é uma decorrência lógica da segurança, conforme aduz Pontes de Miranda:

"Em toda parte onde a retroatividade das leis fosse admitida, não somente a segurança não existiria mais, como nem mesmo a sua sombra [...] $\mathrm{O}$ homem, que ocupa apenas um ponto no tempo como no espaço, seria um ser bem infeliz se ele não pudesse se acreditar em segurança mesmo em relação à sua vida passada; para essa porção de sua existência, já não carregou ele todo o peso de seu destino? O passado pode deixar mágoas, mas ele termina todas as incertezas [...] Longe de nós, a ideia dessas leis de duas faces que, tendo sem cessar um olho sobre o passado e outro sobre o futuro, secariam a fonte da confiança e se converteriam em um princípio eterno de injustiça, de reversão e de desordem. Por que, dir-seá, deixar impunes os abusos que ocorressem antes da lei, que se promulga, para reprimi-los? Porque não é necessário que o remédio seja pior do que o mal [...] Não é necessário exigir que os homens sejam antes da lei o que eles apenas devam sê-lo por meio dela."103

Dessa assertiva já se justifica a irretroatividade da lei, consagrada, portanto, para regrar o futuro. O problema é que do ponto de vista do tempo, tanto o Poder Executivo quanto o Poder Judiciário estão voltados para o passado, para o que pôs o legislador, atuando em estrita vinculação à lei, à Constituição, ao Direito.

O futuro é olhado, sem dúvida, na forma de passado-futuro, ou seja, pautando-se pela observância daquilo que já filtrou o legislador. Do ponto de vista dos conceitos, em que se expressam as normas gerais (regulamentos) ou individuais (atos administrativos ou sentenças), a determinação, a concreção serão ainda maiores do que aquelas constantes das leis.

Os regulamentos serão dotados de maior concreção, mas ainda conservarão a generalidade e a abstração normativas. Os atos individuais terão, no entanto, compreensão máxima, porém nenhuma generalidade, e mínima extensão. O princípio da irretroatividade,

103 Cf. PONTES DE MIRA NDA, Francisco Cavalcanti. Comentários à Constituição de 1967, com a Emenda n. 1, de 1969. 2. ed. São Pau lo: Revista dos Tribunais, 1974. t. V, p. 26. 
em rigor, não lhes diz respeito. Essa a razão mais profunda, que explica a ausência de consagração expressa do princípio em relação ao Poder Executivo e ao Poder Judiciário ${ }^{104}$.

Espera-se que ambos os Poderes (Executivo e Judiciário) cumpram sua função constitucional, qual seja, a de respeitar as leis, a de cumpri-las estritamente. E como as leis não retroagem, porque isso não é de sua natureza, não podem os referidos Poderes retroagir.

O sistema trabalha com a seguinte lógica: as normas regulamentares e os demais atos normativos do Poder Executivo somente podem viabilizar a execução das leis. Em decorrência, jamais retroagem ou determinam, validamente, a invasão do passado, já que a lei, à qual se vinculam, não poderá fazê-lo. É o que corretamente determina o art. 99 do CTN: "O conteúdo e o alcance dos decretos restringem-se aos das leis em função das quais sejam expedidos, determinados com observância das regras de interpretação, estabelecidas nesta lei.".

Nesse tema, estão envolvidos os seguintes princípios constitucionais, inerentes às Repúblicas democráticas: (a) o da separação de poderes; (b) o da indelegabilidade de funções (arts. $1^{\circ}$, $2^{\mathrm{o}}$ e 84 , IV) e da legalidade (arts. 5ํㅡㄴ II; 37; e 150, I) - todos dispositivos da Constituição da República -, princípios esses considerados esteio fundamental da democracia brasileira.

O decreto regulamentar, no sistema jurídico pátrio, tanto à luz das Constituições brasileira anteriores como sob a égide da Constituição de 1988, restringe-se a possibilitar a fiel execução da lei. É o que dispõe o artigo colacionado a seguir:

“Art. 84. Compete privativamente ao Presidente da República:

$[\ldots]$

IV - sancionar, promulgar e fazer publicar as leis, bem como expedir decretos e regulamentos para sua fiel execução." (sem grifo no original)

O que se abala quando se permite ao Poder Executivo mudar a própria lei é, evidentemente, a República, são as instituições públicas fundamentais e estruturadoras da ordem jurídica nacional. Ao decreto regulamentar cabe tão somente viabilizar a aplicação

104 DERZI, Misabel Abreu Machado. Modificações da jurisprudência: proteção da confiança, boa-fé objetiva e irretroatividade co mo limitações constitucionais ao poder judicial de tributar, p. 418/419. 
da lei, realizando-a, cumprindo-a, efetivando-a, tudo direcionado para a garantia da observância fiel de seus comandos ${ }^{105}$.

O tempo que o Poder Executivo contempla é, portanto, o mesmo quando produz normas regulamentares, viabilizando a execução das leis; é o tempo passado, o input do sistema, no que tange tão somente a buscar as leis que fundam seus atos normativos.

Não poderá pretender atingir o passado, anulando direitos, restringindo-os ou criando deveres que a lei não instituiu. O que a lei não pode fazer, muito menos poderão os regulamentos de execução. O olhar do passado é posto no sentido de que a lei é prévia, necessariamente prévia aos regulamentos ${ }^{106}$.

Assim como os regulamentos, sob o aspecto temporal, os atos administrativos individuais, no instante em que se dão, também incorporam o passado, pois restritos às leis que lhes são prévias. Os casos concretos, que provocam a prática do ato, e a lei que os rege estão no passado, em relação à prática do ato administrativo. Também os casos são reconstituídos, e a lei “interpretada” pela Administração tributária. Mas tudo de forma provisória, pois somente o Poder Judiciário aplica e interpreta definitivamente a lei ${ }^{107}$.

\subsubsection{O Princípio da Confiança Legítima e o Tempo do Poder Executivo}

Uma questão relevante se coloca do ponto de vista dos erros da Administração. Os atos administrativos são, uma vez inquinados de vícios, isto é, errôneos, falseados ou ilegais, porque distantes das leis que os legitimam, anuláveis por provocação judicial ou alteráveis de ofício. Ressurgem, então, fortes, nessas ocasiões, os princípios da proteção da confiança, da irretroatividade e da boa-fé - sempre invocados em favor do administrado, do cidadão/contribuinte -, que confiara na aparência da legitimidade dos atos $\operatorname{administrativos}^{108}$.

\footnotetext{
105 DERZI, Misabel Abreu Machado. Modificações da jurisprudência: proteção da confiança, boa-fé objetiva e irretroatividade co mo limitações constitucionais ao poder judicial de tributar, p. 454.

106 Ibidem, p. 455.

107 Art. 5ํㅡㄹ inciso XXXV, da CF: "a lei não excluirá da apreciação do Poder Judiciário lesão ou ameaça a direito".

${ }^{108}$ DERZI, Misabel Abreu Machado. Op. cit., p. 457.
} 
Como dito, os atos normativos regulamentares do Poder Executivo jamais retroagem, uma vez que as leis, nas quais se baseiam, não podem retroagir, por expressa proibição da Lei Maior. Trata-se de uma consequência lógica. Nesse passo, não seria necessário declará- lo a Constituição da República. A dedução a que se chega não configura nem mesmo dedução analógica, trata-se de mero corolário do princípio da legalidade.

A questão apresenta-se de modo diverso, relativamente ao efeito dos erros advindos nessas regulamentações, se eles eram favoráveis aos cidadãos contribuintes. Evidente que esses erros podem e devem ser retificados, mas as consequências das correções efetuadas serão diferentes. A Administração tributária, com base na mesma lei, após ter publicado normas regulamentares, mais favoráveis ao contribuinte, pode alterar seu entendimento, considerando o primeiro ato, viciado. Ou mesmo, sem ter havido vício, poderá a Administração mudar as normas baixadas, para aperfeiçoar a legislação, adotando outra interpretação, admissível no espaço compreensivo da lei?

Mizabel Derzi afirma que sim. Nessa circunstância afloram os princípios da irretroatividade, da proteção da confiança legítima e da boa-fé objetiva, em plena força. Os princípios aludidos ressurgem, naqueles pontos em que as garantias se fragilizam, pois os atos modificativos representam um agravamento da situação do cidadão/contribuinte. Se ele confiou na legislação vigente e se comportou exatamente de acordo com ela, obedecendo aos comandos de seu credor, em razão dos atos indutores de confiança praticados pelo próprio Poder Executivo, não seria ético nem justo que fosse punido retroativamente, ou, mesmo, em certas circunstâncias, que não fossem mantidos aqueles atos para o passado ${ }^{109}$.

Portanto, exatamente nas mudanças das normas editadas, para onerar mais intensamente o contribuinte, o administrado, embora se tivessem mantido iguais as mesmas leis que as fundamentam, é que emergem os princípios da irretroatividade, da proteção da confiança legítima e da boa-fé.

Em síntese, são situações de aplicação dos princípios da irretroatividade, da proteção da confiança e da boa-fé objetiva, se presentes os requisitos necessários: (a) as mudanças de normas regulamentares e outras complementares, agravadoras dos deveres dos contribuintes e restritivas do exercício de seus direitos, sem que tenha ocorrido, para

${ }^{109}$ DERZI, Misabel Abreu Machado. Modificações da jurisprudência: proteção da confiança, boa-fé objetiva e irretroatividade co mo limitações constitucionais ao poder judicial de tributar, p. 351. 
isso, alteração prévia da lei em que se fundam; (b) as mudanças de atos administrativos individuais, de concreção e aplicação das leis, nos lançamentos, autuações e cobranças de tributos, que onerem de forma mais intensa os contribuintes; e (c) as respostas às consultas, as informações e declarações da Administração tributária, capazes de guiar-lhes a conduta.

A questão será, então, de retorno à legalidade da atividade administrativa, de recomposição do Estado de Direito.

Será desnecessário indagar se o contribuinte acred itava na lei, no ato ou no decreto, se a norma, prejudicial aos seus direitos, for ilegal. Desnecessário também será verificar a "confiança" subjetivamente criada ou mesmo a boa-fé do contribuinte. Esse campo cristaliza, de tal modo a segurança jurídica, com tal força objetiva, que não ressurge a confiança. Ela está ali, submersa, pressuposta por detrás da segurança, do Estado de Direito. Ela não precisa ser percebida, pois é evidente que fundamenta o restabelecimento da legalidade dos atos administrativos.

A confiança sistêmica e difusa reside nas leis, nas expectativas normativas criadas pelo legislador, na fonte de produção do Direito, que a Constituição elege, primária e precipuamente, sobre qualquer ato do Poder Executivo.

A nulidade do ato administrativo ilegal, por si, sustenta, sem necessidade de atuação, as especificidades das regras da proteção da confiança e da boa-fé.

O problema resulta exatamente no fato de que com a extinção do ato administrativo ilegais, seja pela provocação judicial, seja pela revisão do ato pela Administração Pública, o novo ato que substitui aquele inquinado de vício acaba por retroagir. Como a irretroatividade é aplicada apenas na esfera do Poder Legislativo, há uma lacuna de proteção do administrado, que é justamente o momento em que o princípio da proteção da confiança legítima entra em cena.

Daí por que, segundo Claus-Wilhelm Canaris, a responsabilidade pela confiança manifesta-se em caráter subsidiário e, por definição, somente tem lugar onde as possibilidades de segurança, disponibilizadas e reguladas pela ordem jurídica, fracassam ético-juridicamente ${ }^{110}$.

Misabel Derzi conclui que o princípio de proteção da confiança tem aplicação mais restrita no Brasil exatamente porque, diversamente do ordenamento jurídico alemão, a

${ }^{110}$ Cf. CA NARIS, Claus-Wilhelm. Die Vertrauenshaftung im Deutschen Privatrecht, p. 273-287. 
Constituição Federal de 1988 tem dispositivo expresso que veda a retroatividade tributária. Segundo a autora, a carência de dispositivo expresso em relação à irretroatividade das leis no Direito Constitucional alemão - exceto no que tange ao Direito Penal -, projeta o tratamento do tema para o campo do princípio da confiança que, em seu caráter de pano de fundo, aflora em toda a sua plenitude, na jurisprudência e na dogmática dos germanos ${ }^{111}$.

No Brasil, não se reconhece nenhuma incompatibilidade entre a proteção da confiança e a irretroatividade; ao contrário, a proteção, que a Constituição prevê, é tão forte - e o mandamento já conta com mais de século de prática -, que ela se cristaliza por detrás dos institutos. Inexiste a necessidade de se testar os requisitos da confiança: o ato do legislador, desencadeador da confiança, a base da confiança, a confirmação da confiança, os investimentos feitos pelo cidadão, as consequências desencadeadas, positivas ou negativas, e o sopesamento do interesse público na mudança da lei. Embora ali latente, mas cristalizada, a proteção da confiança legítima ou justificada não se manifesta, porque ela está pressuposta, pode apenas servir de explicação ou fundamento da própria escolha da Constituição.

Isso explica por que, não sendo rica a literatura nacional no tocante à proteção da confiança legítima, nem mesmo da boa-fé objetiva no Direito Tributário, no entanto, é bastante farta no que diz respeito à segurança jurídica, à previsibilidade e ao princípio da não surpresa. No Brasil, apenas nos espaços restritos e controversos ou de fragilidade do princípio da irretroatividade é que surgirá, como garantia ético-jurídica, o princípio da proteção da confiança $^{112}$.

De tudo quanto exposto, viu-se, portanto, que o sistema de Luhmann explica o ordenamento jurídico como mecanismo de proteção das expectativas normativas e dirigido à solução de conflitos.

Concluiu-se que o tempo do Poder Legislativo é o futuro. Ou seja, a lei, embora tenha captado aspectos políticos, sociais, econômicos, está direcionada para o regramento do futuro.

\footnotetext{
${ }^{111}$ DERZI, Misabel Abreu Machado. Modificações da jurisprudência: proteção da confiança, boa-fé objetiva e irretroatividade co mo limitações constitucionais ao poder judicial de tributar, p. 387.

112 Ibidem, p. 414.
} 
No Brasil, por força do princípio da irretroatividade da lei, não se preocupou o Constituinte em fazer que a irretroatividade valesse também para a atuação do Poder Executivo e do Poder Judiciário.

Essa omissão tem uma lógica. Como o Poder Executivo não pode expedir atos administrativos ou regulamentos fora dos limites da lei - e bem assim o Poder Judiciário é apenas aquele que aplica ao caso concre to a lei criada pelo Poder Legislativo -, o princípio da irretroatividade estaria respeitado pela via reflexa.

Acontece que, quando o ato administrativo possui algum vício que o torne ilegal, a irretroatividade da lei é insuficiente para proteger o administrado que, por ter confiado na aparência de legitimidade do ato, não pode ser sancionado ou ter seu patrimônio diminuído em razão da nulidade do ato.

Surge, nesse ponto, o princípio da confiança legítima como mecanis mo de proteção do cidadão, que passa a impedir, em maior ou menor medida, a retroação dos efeitos da ilegalidade do ato.

Por essa razão, afirma-se que o princípio da confiança legítima tem lugar quando os demais instrumentos de defesa do administrado fracassam ético-juridicamente.

Essa consideração sobre o campo de aplicação do princípio da confiança legítima na esfera do Poder Executivo será retomada no Capítulo 7, por ocasião da análise do art. 100, inciso III, do CTN.

\subsection{Os Primeiros Estudos do Princípio da Confiança no Brasil}

No Brasil, o princípio da confiança legítima foi, inicialmente, investigado pelo Professor Almiro do Couto e Silva, que, já no início dos anos 80 do século XX, aprofundou seus estudos a respeito da segurança jurídica, sob novo enfoque.

$\mathrm{O}$ autor constatou a existência de situações em que ao mesmo tempo em que a justiça e a segurança jurídica se completavam, elas poderiam ficar em posições contrapostas. O exemplo mais contundente dessa situação é o caso da prescrição, que compreende o sacrifício da justiça em favor da segurança jurídica. Inseridos nessa mesma 
órbita estão os institutos da coisa julgada e a preclusão processual, dado que ambos impossibilitam a reanálise dos atos do Estado, ainda que injustos, ilegais ou contrários ao Direito.

Esses conflitos também se verificam entre o princípio da legalidade da Administração Pública e da proteção da confiança dos administrados que acreditaram na legalidade dos atos administrativos que os favoreceram com benefícios posteriormente considerados ilegais ou indevidos. Ora dá-se prevalência à segurança jurídica em prejuízo da justiça, ora o inverso. Da mesma forma, ora dá-se maior importância ao princípio da legalidade da Administração Pública em detrimento da proteção da confiança dos administrados, ora dá-se novamente o inverso ${ }^{113}$.

O princípio da segurança jurídica revelaria, assim, a face geral da segurança jurídica, protegendo o interesse de todos, apesar, eventualmente, do interesse de alguns; ao passo que o princípio da proteção da confiança garantiria o interesse de um ou de alguns apesar, eventualmente, do interesse de todos. O primeiro seria vinculado, portanto, à justiça geral, ao passo que o segundo, à justiça individual ${ }^{114}$.

Daí afirmar-se que o princípio da proteção da confiança, em rigor, não é mera decorrência, obtida por dedução, do princípio da segurança jurídica, mas, em vez disso, uma limitação ou um corolário limitativo desse princípio ${ }^{115}$.

$\mathrm{Na}$ verdade, conforme adverte Almiro do Couto e Silva, o conflito entre justiça e segurança jurídica só está presente quando se toma a justiça como um valor absoluto, de sorte que o justo nunca pode transformar-se em injusto, nem o injusto jamais perderá essa natureza. A contingência humana, entre outros fatores - tempo, espaço, cultural etc. -, impõe temperamentos e adaptações, sob pena de, se assim não se proceder, correr-se o risco de agir injustamente ao cuidar de fazer justiça.

Isso explica-se pelo fato de que a tolerada permanência do injusto ou do ilegal pode dar causa a situações que, por estarem arraigadas e consolidadas, seria incorreto desconstituí-las, só pela lembrança ou pela invocação da injustiça ou da ilegalidade que originariamente acometia $\mathrm{o}$ ato.

\footnotetext{
${ }^{113}$ ACHTERBERG, Norbert. Allgemeines Verwaltungsrecht. Heidelberg: C. F. Müller, 1982. p. 22.

114 Á VILA, Hu mberto Berg mann. Segurança jurídica - entre permanência, mudança e realização no dire ito tributário. São Paulo: Malheiros, 2011.p. 363.

115 Ibidem, p. 364.
} 
De fato, quando se diz que em determinadas circunstâncias a segurança jurídica deve preponderar sobre a justiça, o que se está afirmando, em rigor, é que o princípio da segurança jurídica passou a exprimir, naquele caso, diante das peculiaridades da situação concreta, a justiça material. Segurança jurídica não é, aí, algo que se contraponha à Justiça; é ela a própria Justiça ${ }^{116}$.

Isso não significa, no entanto, que seja fácil discernir, diante do caso concreto, qual o princípio que lhe é adequado, de modo a assegurar a realização da Justiça: o da legalidade da Administração Pública ou o da segurança jurídica? A invariável aplicação do princípio da legalidade da Administração Pública deixaria os administrados, em inúmeras situações, atônitos, intranquilos e até mesmo indignados pela conduta do Estado, se a este fosse dado, sempre, invalidar/modificar seus próprios atos sob o argumento de ter adotado nova interpretação e de haver finalmente percebido, após o transcurso de certo lapso de tempo, que eles eram ilegais, não podendo, portanto, como atos nulos, dar causa a qualquer consequência jurídica para os destinatários.

No item a seguir, analisar-se-ão o conteúdo do princípio da legalidade e a evolução histórica que culminou na sua relativização quando cotejado com o princípio da segurança jurídica, notadamente em sua feição subjetiva, qual seja, a do princípio da confiança legítima.

\subsubsection{A Origem do Princípio da Confiança Legítima e a Evolução do Princípio da Legalidade}

O Estado liberal, como se sabe, tratava exclusivamente de garantir o livre desenvolvimento das forças e impulsos sociais e econômicos, com um mínimo de interferência.

Assim, não havia grandes questionamentos acerca da estrutura jurídica do Estado Liberal, uma vez que o Estado era simples e se ocupava quase somente dos serviços de segurança externa e interna, justiça, obras públicas, saúde e educação - em medidas

\footnotetext{
${ }^{116}$ COUTO E SILVA, Almiro do. Princípios da legalidade da administração pública e da segurança jurídica no estado de direito contemporâneo. RPGE, v. 27, n. 57, p. 18.
} 
incomparavelmente mais modestas das atuais. Em razão disso, também era singelo o relacionamento entre o Estado e o Direito.

Essa "simplicidade" do Estado Liberal foi rompida pela Revolução Industrial e pelos movimentos sociais que foram deflagrados em decorrência dela.

Desse modo, as linhas que separavam, de forma muito firme, o Estado Liberal da sociedade, começam a desaparecer, passando o Estado a incumbir-se de propiciar benefícios e vantagens aos administrados, oferecendo, por exemplo, assistência e previdência sociais, programas habitacionais etc. Dito de outra maneira, o Estado liberal passou à feição de Estado social ${ }^{117}$.

Essa expansão do Estado contemporâneo, com a ampliação do leque de serviços públicos, teve implicações relevantes no plano jurídico, com repercussões significativas sobre o princípio da legalidade da Administração Pública, na sua formulação original.

Em síntese apertada, esse novo papel do Estado representou uma crise no princípio da legalidade da Administração Pública, porque: (a) o (novo) Estado passou a exigir decisões prontas, impossíveis muitas vezes de serem tomadas pela via legislativa assim, utiliza-se uma delegação disfarçada que consiste na atribuição de competência amplíssima a entidades e órgãos da Administração Pública; (b) a essas formas veladas de delegação legislativa conecta-se diretamente a importância assumida pelas fontes infralegais do Direito, como, por exemplo, regulamentos, resoluções, circulares, portarias etc.; (c) o Estado utiliza, cada vez mais, nos diplomas normativos, cláusulas gerais, de conteúdo vago e elástico, e conceitos jurídicos indeterminados ${ }^{118}$, o que, em última análise, resulta em um campo aberto de decisão muito maior ao agente administrativo, quase um exercício de poder discricionário; e (d) ao ampliação da área de atuação do Estado correspondeu o desmedido aumento da legislação, tornando impossível até mesmo aos especialistas conhecê-la na integridade.

Além do problema ligado ao volume, a legislação também ganhou em complexidade, culminando com a difícil compreensão dos textos legais. Todos esses aspectos aqui tangenciados de modo sucinto distanciam, obviamente, a lei dos seus

\footnotetext{
${ }^{117}$ COUTO E SILVA, Almiro do. Princípios da legalidade da administração pública e da segurança jurídica no estado de direito contemporâneo. RPGE, v. 27, n. 57, p. 21.

118 Um exemplo dessa situação, no campo do Direito Tributário, é exatamente o Fator Acidentário de Prevenção (FAP), cujo diplo ma legal que o instituiu deixou para a Administração Pública a tarefa de editar regulamentos, resoluções e demais atos administrativos para completar a norma tributária.
} 
destinatários, o que, se não torna o princípio da legalidade da Administração Pública uma falácia, pelo menos o enfraquece consideravelmente, caso se tenha presente o sentido e a função para os quais foi concebido ${ }^{119}$.

Em razão disso, tornou-se necessário corrigir as distorções causadas ao princípio da legalidade da Administração Pública, resultantes do esquecimento de que sua origem radica na proteção dos indivíduos contra o Estado.

Desse modo, uma das providências para que se possa corrigir a aplicação do princípio da legalidade foi - e é - revisitar a ideia que a Administração pode desfazer seus próprios atos, quando nulos. É que esse aspecto contraria as razões que conduziram ao surgimento do princípio da legalidade, direcionadas todas para a defesa do indivíduo perante o Estado. Essa noção de que o Estado tem sempre o poder de anular seus atos ilegais decorre da verdade indiscutida no direito privado, desde o Direito Romano, de que o nulo jamais produz efeitos, convalida, convalesce ou sana, sendo ainda insuscetível de ratificação.

Se assim efetivamente é, então caberá sempre à Administração Pública revisar seus próprios atos, desconstituindo-os de ofício, quando eivados de nulidade, do mesmo modo como sempre será possível, quando válidos, revogá-los, desde que inexista óbice legal e não tenham gerado direitos subjetivos.

Insinuou-se então, paulatinamente, a ideia da proteção à boa-fé ou da proteção à confiança, a mesma ideia, em suma, de segurança jurídica cristalizada no princípio da irretroatividade das leis ou no de que são válidos os atos praticados por funcionários de fato, apesar da manifesta incompetência das pessoas de que eles emanaram.

Foi por meio da jurisprudência firmada pelos Tribunais alemães ${ }^{120}$, na metade da

${ }^{119}$ COUTO E SILVA, Almiro do. Princípios da legalidade da administração pública e da segurança jurídica no estado de direito contemporâneo. RPGE, v. 27, n. 57, p. 20.

${ }^{120}$ A origem do princípio da confiança legítima não é um tema pacífico. Larenz re lata que coube a Heinrich Stoll, em 1923, as sociar a culpa in contrahendo ao princípio da proteção da confiança. A partir daí, por meio dos trabalhos de Stoll e Ballerstedt, a Dogmática transcendeu as possibilidades literais da lei em favor de um pensamento orientado por valores. Larenz conclui que o Tribunal Constitucional ale mão derivou, do Estado de Direito, princípio co mo o da proporcionalidade (no sentido da justa medida e de menor restrição possível); e o princípio da proteção da confiança na relação entre a legislação e o cidadão, com que a Corte trabalhou a irretroatividade das leis (cf. LARENZ, Karl. Metodologia da ciência do direito. Trad. José de Sousa Brito e outro. 2. ed. Lisboa: Fundação Calouste Gulbenkian, 1978. p. 600-601). Em outra passagem, afirma que o princípio da proteção da confiança, em textos isolados, já era invocado na Alemanha, na época da Constituição de Weimar, mas foi após as Grandes Guerras que demonstrou sua força, desenvolvendo-se, a partir daí, trabalhos dogmáticos muito profundos. O autor lembra que as teorias germânicas tiveram reflexos em outros países, em especial na Suíça, onde o princípio da boa-fé obscurecia o entendimento relativo à 
década de 50 do século XX, que se eliminou a faculdade de o Estado invalidar os atos administrativos nulos por serem ilegais, quando, com a prolongada e complacente inação do Poder Público, hajam produzido benefícios e vantagens para os destinatários.

Portanto, a proteção da confiança legítima aparece na jurisprudência alemã ${ }^{121}$, por meio de uma decisão do Tribunal Administrativo Superior de Berlim de 14 de novembro de 1.1956 (DVBL, 1957, 503). Tratava-se do seguinte caso: a demandante, uma viúva de funcionário, mudou da República Democrática Alemã à época para Berlim-Leste depois de lhe haver sido prometido, por ato administrativo, a concessão de rendimentos de pensão. Um ano depois a autoridade competente comprovou que os pressupostos jurídicos para a concessão não existiam, e os rendimentos de pensão, portanto, haviam sido concedidos de maneira equivocada. Em consequência, a Administração Pública retratou o ato administrativo, suspendeu os pagamentos e exigiu da demandante a restituição dos rendimentos pagos indevidamente. Isso correspondia, sem mais, à jurisprudência vigente. O Tribunal Administrativo Superior de Berlim decidiu, todavia, a favor da demandante. Ele comprovou que, no caso concreto, deveria ser observado não só o princípio da legalidade, mas também o princípio da proteção à confiança. A demandante confiou na existência do ato jurídico e, em conformidade com isso, alterou decisivamente suas condições de vida. Como, no caso concreto, o interesse da confiança preponderava, o ato administrativo não deveria ser retratado.

proteção da confiança. Após os trabalhos sistemáticos de Günter, Kisker e Günter Pütner, na década de 70 do século XX, e, posteriormente, os de Volkmar Götz, o tema entrou definitivamente no direito público e nas fundamentações da Corte Constitucional alemã. Outra afirmação sobre a origem do princípio da confiança legítima pode ser encontrada na jurisprudência antiga da Suíça, datada de 1923, quando ocorreu a primeira revelação do problema. Em determinado processo movido por uma comunidade de moradores de Berna contra o Estado, que pretendia edificar em seu território, determinado prazo processual foi observado pela autora da ação, segundo a forma de contagem e a duração postas em prática há mu itos anos. Weber-Dürler relata que, apesar disso, o Conselho da Presidência afastou-se da prática até então adotada, para deslocar o termo in icial de contagem a u ma data anterior, a partir da qual estaria configurada a preclusão. O Tribunal Federal, ao decidir o conflito, reconheceu o direito da comunidade, que fora decepcionada em sua confiança pelo Estado. Anos depois, em 1930, o Tribunal de segunda instância da Basileia, embora tivesse declarado, expressamente, que alteraria o seu entendimento para o futuro, deixou de aplicar a nova prática no caso concreto sub judice, dando preferência à segurança jurídica. Assim comenta Weber-Dürler os precedentes: "vis to de hoje, o Tribunal Superior da Basiléia - com o aval do Tribunal Federal - realizou u ma verdadeira prestação pioneira: ele efetuou uma certa alteração jurisprudencial apenas para o futuro, tratou o caso em tela levando em consideração a proteção da confiança, conforme a prática que valia então até aquela data. A decisão demonstrou um belo exemplo da assim chamada prospective overruling, aquela mudança da jurisprudência que, aproximadamente desde 1850, é praticada nos Estado Unidos e que é exigida pela doutrina americana desde 1917. A literatura alemã descobriu o estilo de decisão difundido nos Estados Unidos apenas após 1950, apesar de, es pecialmente, monografias sobre o modelo a mericano tere m tido efe ito frutífero" (DERZI, Misabel Abreu Machado, Modificações da jurisprudência: proteção da confiança, boa-fé objetiva e irretroatividade como limitações constitucionais ao poder judicial de tributar, p. 505/506).

121 RIBEIRO, Ricardo Lodi. A segurança jurídica do contribuinte: legalidade, não-surpresa e proteção à confiança legítima. Rio de Janeiro: Lu men Juris, 2008. p. 228/229. 
O Tribunal Administrativo Federal confirmou a sentença do Tribunal Administrativo Superior de Berlim (BVerwGE 9, 251) e, em época posterior, desenvolveu, em numerosas decisões, uma doutrina da retratação ampla e diferenciada. O ponto de partida foi o entendimento que a questão sobre a revisão de atos administrativos beneficentes antijurídicos é dominada por dois princípios, ou seja, de um lado, pelo princípio da legalidade da administração, que exige a eliminação de atos administrativos antijurídicos; e, de outro, pelo princípio da confiança legítima, que pede a manutenção do ato administrativo beneficente. Como ambos os princípios requerem prevalência, mas também estão em conflito um com o outro, deve, segundo entendimento do Tribunal Administrativo Federal, ser ponderado e examinado, no caso particular, a qual interesse ao interesse público na retratação ou ao interesse individual na existência do ato administrativo - deve-se a primazia.

Nisso também são possíveis soluções que diferenciam, por exemplo, uma retratação limitada objetiva ou temporalmente. Para a fundamentação da proteção à confiança o Tribunal Administrativo Federal refere-se, em parte, ao princípio da lealdade e boa-fé e, em parte, ao princípio da certeza jurídica. Iria contradizer a lealdade e boa-fé se a autoridade fosse apoiar-se na antijuridicidade de um ato administrativo por ela mesma publicado em prejuízo do cidadão. De outra parte, a certeza jurídica exige que um ato administrativo não só se torne eficaz juridicamente, apesar de possível antijuridicidade, mas também que se torne juridicamente eficaz quando o cidadão partiu e poderia partir da eficácia jurídica. Por meio da certeza jurídica, que radica no Estado de Direito e, com isso, ela mesma possui hierarquia constitucional, a proteção à confiança também obtém seu fundamento jurídico-constitucional. Esse entendimento é relevante porque permite que a proteção essa seja alçada ao mesmo nível do princípio da legalidade que, igualmente, radica no direito constitucional ${ }^{122}$.

Com a decisão em comento, a doutrina alemã adere com grande entusiasmo à nova teoria, naquilo que Garcia Luengo denominou marcha triunfal do princípio da proteção à confiança $^{123}$, até sua consagração como princípio constitucional pelo Tribunal

\footnotetext{
122 MAURER, Hartmut. Elementos do direito administrativo alemão. Trad. Dr. Luís Afonso Heck. Porto Alegre: Sergio Antonio Fabris, 2001.p. 69-71.

123 GA RCIA LUENGO, Javier. El principio de la proteción de la confianza en el derecho administrativo. Madrid: Civitas, 2002. p. 30.
} 
Constitucional Alemão, nos anos 70 do século $\mathrm{XX}^{124}$. O legislador germânico então decide positivá-lo no $§ 48$ da Lei do Procedimento Administrativo de $1976^{125}$, em determinação que acabou reproduzida na lei societária e fiscal ${ }^{126}$. Após sua consolidação no Direito positivo alemão, a ideia se universaliza com a adesão da Corte de Justiça das Comunidades Europeias ao princípio da proteção da confiança legítima, tomado como regra fundamental do Direito comunitário, em paulatino processo evolutivo que se completa em $1978^{127}$.

\subsubsection{A Evolução do Princípio da Legalidade no Brasil}

No País, no passado, a doutrina silenciava a respeito de como resolver situações irregulares, nascidas de atos administrativos inválidos, mas que são, por considerável lapso de tempo, toleradas pela Administração Pública ${ }^{128}$.

Seabra Fagundes, em 1950, ao tratar de estabelecer o cotejo entre a invalidade dos atos jurídicos no direito privado e no direito público, escreve de maneira pioneira:

${ }^{124}$ CALMES, Sylvia. Du principe de protection de la confiance légitime en droits allemand, communautaire et français. Paris: Dalloz, 2001. p. 16.

125 A Lei de Processo Administrativo alemã, de 25 de maio de 1976, prevê que os atos admin istrativos válidos favoráveis aos administrados, ou seja, que lhes concedem benefícios, não poderão ser revogados (em consagração ao princípio da proteção da confiança), salvo em expressas e específicas hipóteses, com efeitos tão somente para o futuro (art. 49.2):

“(i) Caso a revogação seja expressamente autorizada em lei ou se o próprio ato ad min is trativo assim a previa, uma vez que, sendo esta circunstância previsível desde o princípio, não poderá o administrado se socorrer da confiança legítima;

(ii) Caso a manutenção do ato administrativo esteja sujeita ao cumprimento de determinadas condições ou requisitos não preenchidos pelo administrado ou não realizados no prazo previsto;

(iii) Caso os fatos supervenientes demonstrem que a autoridade administrativa não deveria adotá-los em face das circunstâncias atuais, já que a sua manutenção coloca em perigo o interesse público (ameaça ao Estado ou à sociedade), sendo menos prejudicial a sua revogação;

(iv) Caso a superveniência de alterações normativas determine que as autoridades administrativas emitentes do ato não são competentes para tanto, des de que o beneficiário não tenha exercido o direito ali consignado ou recebido qualquer prestação com base no ato administrativo e a falta de revogação possa colocar em risco o interesse público; e

(v) para prevenir ou ext inguir graves prejuízos ao bem-estar coletivo."

${ }^{126}$ MAURER, Hart mut. Elementos de direito administrativo alemão, p. 72.

${ }^{127}$ CALMES, Sylvia. Op. cti., p. 24.

${ }^{128}$ Da mesma forma em relação às mudanças abruptas de posicionamento do Poder Judiciário. 


\begin{abstract}
"A infringência legal no ato administrativo, se considerada abstratamente, aparecerá sempre como prejudicial ao interesse público. Mas, por outro lado, vista em face de algum dado concreto pode acontecer que a situação que resulte do ato, embora nascida irregularmente, torne-se útil àquele mesmo interesse. Também as numerosas situações alcançadas e beneficiadas pelo ato vicioso podem aconselhar a subsistência dos seus efeitos" ${ }^{\prime 129}$.
\end{abstract}

Nessas situações, segundo o referido autor, duas alternativas poderiam abrir-se ao administrador, conforme as circunstâncias: praticar novo ato, sem as deficiências do anterior, ou manter-se em silêncio, "renunciando tacitamente ao direito de invalidá-lo"130.

$\mathrm{Na}$ ótica da época, o problema era enxergado, como faculdade e não dever, que teria a Administração de decretar a anulação de seus atos administrativos inválidos, faculdade a qual poderia renunciar, repetind o o ato, quando isto fosse possível, sem os vícios que apresentava ou pela ratificação tácita.

Não cogitara, Seabra Fagundes, ainda, da possibilidade de sanar o ato nulo, pelo transcurso do tempo conjugado à complacência do Poder Público, o que daria ao destinatário, eventualmente atingido pela anulação tardia, o direito subjetivo de rebelar-se contra esta última medida ${ }^{131}$.

Ao identificar a mesma problemática observada por Seabra Fagundes, o doutrinador Miguel Reale, no livro que trata da revogação e anulamento do ato administrativo ${ }^{132}$, sustenta que o exercício do poder anulatório, que cabe à Administração Pública, está sujeito a um prazo, razoável, como exigência implícita no due process of law. Explica Reale, comentando a posição de José Frederico Marques, que

“[...] haverá infração desse ditame fundamental toda a vez que, na prática do ato administrativo, for preterido algum dos momentos essenciais a sua ocorrência; forem destruídas, sem motivo plausível, situações de fato, cuja continuidade seja economicamente aconselhável, ou se a decisão não corresponder ao complexo de notas distintas da realidade social tipicamente configurada em lei" ${ }^{133}$.

\footnotetext{
${ }^{129}$ FA GUNDES, Seabra. O controle dos atos administrativos pelo Poder Judiciário. Rio: Konfino, 1950. p. 60-61.

${ }^{130}$ Ibidem, loc. cit.

${ }^{131}$ Nesse mo mento, o te ma ainda não se relaciona com a segurança jurídica.

132 REA LE, Miguel. Revogação e anulamento do ato administrativo. Rio de Janeiro: Fo rense, 1968. p. 87.

133 Ibidem, p. 85.
} 
Uma solução proposta era de que, no Brasil, adaptando-se à realidade pátria a solução que o Conselho de Estado deu ao caso Cachet, no Direito francês, o prazo concedido ao Poder Público para anular seus atos fosse idêntico ao fixado em lei para a impetração do mandado de segurança, ou seja, cento e vinte dias. Reale era contrário à fixação de prazo.

De todo modo, na esteira de Couto e Silva, importa destacar que a supremacia do interesse público impunha (e impõe) divergências substanciais no tratamento da invalidade dos atos administrativos do dispensado aos atos jurídicos de direito privado. Enquanto nesse o nulo não convalesce e nem convalida, os atos administrativos inválidos, nulos ou anuláveis sanam sempre que sobre eles recair uma camada razoável de tempo, com a tolerância da Administração Pública ${ }^{134}$.

José Neri da Silveira comunga de igual pensamento, em parecer exarado em 1965, no qual examina precisamente a possibilidade de anulação de atos administrativos há muito praticados e em conformidade, ainda, com jurisprudência administrativa então dominante. O doutrinador aduz:

“[...] se é certo, em princípio, que não há direito contra a lei e que a administração pode anular os seus atos com infrações a dispositivos legais, consoante ficou largamente analisado acima (itens 38 e 39), não menos exato é que a atividade administrativa possui, em seu favor, uma presunção de legitimidade, e cada ato do Poder Público, oriundo de autoridade competente, há de ter-se, em princípio, como válido, perante os cidadãos, máxime quando, por estes aceito, produza consequências de direito, em prol dos mesmos, de forma pacífica, iterativamente, no decurso de muitos anos, com inquestionada aparência de regularidade" ${ }^{, 135}$.

No referido Parecer, José Neri da Silveira cita opinião do Ministro Orozimbo Nonato, expressa em voto no Supremo Tribunal Federal, nos seguintes termos: "O que se geralmente aceita é que o ato nascido da ilegalidade, revogável se mostra pela administração ou por ela é anulável. Mas, se o ato tem aparência regular e originou direito subjetivo, não pode a revogação ter efeitos" $" 136$.

\footnotetext{
${ }^{134}$ COUTO E SILVA, Almiro do. Princípios da legalidade da administração pública e da segurança jurídica no estado de direito contemporâneo. RPGE, v. 27, n. 57, p. 22.

${ }^{135}$ Parecer publicado no DOE do Rio Grande do Sul, de 24 de novembro de 1965.

${ }^{136}$ REVISTA DE DIREITO ADMINISTRATIVO, Rio de Janeiro, 52/246.
} 
Depois disso, no entanto, a jurisprudência do Supremo Tribunal Federal consolidou-se em favor da preponderância do princípio da legalidade da Administração Pública sobre o da segurança jurídica, cristalizado na famigerada Súmula n⿳⺈ 473, com o seguinte verbete:

“A administração pode anular seus próprios atos, quando eivados de vícios que os tomam ilegais por que deles não se originam direitos, ou revogá-los, por motivo de conveniência ou oportunidade, respeitados os dire itos adquiridos, e ressalvada, em todos os casos, a apreciação judicial" ${ }^{\prime 37}$.

Nessa época, havia, no máximo, pronunciamentos isolados do Supremo Tribunal Federal que contribuíram para modificar essa posição extremamente conservadora e que se poderia qualificar até mesmo de retrógrada, se posta em confronto com as adotadas em outros países ${ }^{138}$.

Assim é que no RMS nº 13.807 , da Guanabara ${ }^{139}$, a $3^{\text {a }}$ Turma do STF - ao decidir sobre caso relacionado com situação de aluno que se formou e passou a exercer profissão

137 Conforme disserta Victor Roberto Corrêa da Silva: "sabe-se que a diferença entre atos nulos e atos anuláveis provém do direito privado, sendo descritas as duas categorias nos arts. 166 e 171 do CC/2002. Assim, segundo esse diplo ma, duas notas básicas diferenciariam os dois tipos de atos inválidos: os atos nulos podem ser invalidados ex officio e não admitem confirmação ou convalidação, enquanto os anuláveis admitem convalidação e precisam de manifestação do interessado para decretar sua anulabilidade. Essa dicotomia entre atos nulos e anuláveis também foi abordada nos arts. $2^{\circ}$ e $3^{\circ}$ da Lei 4.717/1965, e, a nosso sentir, demonstra nítida transposição acrítica de institutos do direito privado para o direito público, sem a devida atualização e constitucionalização.

Com base nessa diferenciação, presente desde os tempos do Código Civil de 1916, o STF editou, na longínqua data de 03.12.1969, a Súmu la 473, em que se diz que 'A Admin istração pode anular seus próprios atos quando eivados de vícios que os tornem ilegais, porque dele não se originam direitos; ou revog á-los, por motivo de conveniência ou oportunidade, respeitados os direitos adquiridos e ressalvada, em todos os casos, a apreciação judicial'. Desde então, toda a jurisprudência e doutrina, em sua grande maioria, vem afirmando que dos atos administrativos nulos, invalidados pela própria Admin istração, em exercício de autotutela, não se gerariam dire itos a serem protegidos.

Esta Súmula 473 - não se negue - ditou o entendimento que prevaleceu na edição de nossa lei de processo administrativo, pois segundo a Lei 9.784/1999: a Administração tem o poder-dever de anular seus atos quando ilegais, ou revogá-los por motivo de conveniência ou oportunidade, sempre respeitando-se os direitos adquiridos (art. 53); para invalidar atos nulos de que decorram efeitos favoráveis aos destinatários a Admin istração terá o prazo de cinco anos, salvo comprovada má -fé (art. 54), ocasião em que este prazo da Admin istração não será observado; de outro lado, se estes atos forem sanáveis, poderão ser convalidados, desde que não afetem interesse público (lato sensu) nem prejudiquem terceiros (art. 55). Deste modo, segundo a Lei 9.784/1999, tem-se que atos administrativos ilícitos podem ser anulados ou revogados, e também convalidados." (CORRÊA DE SOUZA, Victor Roberto. Os desafios da justiça admin istrativa brasileira. Revista de Processo, v. 38, n. 218, p. 133-161, abr. 2013, p. 133).

${ }^{138}$ COUTO E SILVA, Almiro do. Princípios da legalidade da administração pública e da segurança jurídica no estado de direito contemporâneo. RPGE, Porto Alegre, v. 27, n. 57, p. 11-31, p. 30.

${ }^{139}$ RECURSO EM Mandado de Segurança no 13.807/GB. 3- Turma, Relator Ministro Prado Kelly. Revista Trimestral de Jurisprudência, v. n. 37, p. 248-251, 1966. 
amparado em medida liminar em mandado de segurança, depois revogada na sentença guiada pelo voto do Ministro Prado Kelly, entendeu ter a liminar dado causa a uma situação de fato e de direito que não conviria ser inovada. Essa decisão não era outra coisa senão o reconhecimento da sanatória do nulo.

Nesse ponto, faz-se necessário destacar que a consequência natural da sentença declaratória é, realmente, o efeito ex tunc. A esse propósito, é pertinente observar as lições de Teori Albino Zavascki, segundo o qual:

\begin{abstract}
"A sentença que afirma a constitucionalidade da norma tem natureza declaratória: ela declara que a norma é compatível com a Constituição e, consequentemente, é válida. Da mesma forma, é declaratória a sentença que afirma a inconstitucionalidade. É que o vício da inconstitucionalidade acarreta a nulidade da norma, conforme orientação assentada há muito tempo no Supremo Tribunal Federal e abonada pela doutrina dominante entre nós. Assim, a afirmação da constitucionalidade ou da inconstitucionalidade da norma, mediante sentença de mérito ou ação direta ou na ação declaratória, simplesmente declara a validade ou nulidade do preceito normativo, é ex tunc, como ocorre nessa espécie de julgado. 'A Corte', explicou o Ministro Brossard, 'verifica e anuncia a nulidade como o joalhe iro pode afirmar, depois de examiná-lo, que aquilo que se supunha ser um diamante não é diamante, mas um produto sintético. $\mathrm{O}$ joalheiro não fez a pasta sintética, apenas verificou o que era. Também a decisão judicial não muda natureza da lei, como o joalheiro não muda a natureza do diamante. Ela nunca foi lei, ele nunca foi diamante. Aquilo que se supunha ser diamante e que o perito verificou ser um produto sintético, não deixou de ser diamante a partir da verificação do joalhe iro, mas $a b$ initio não passava de um produto sintético. Também a lei inconstitucional. O Judiciário não a fez inconstitucional, apenas verificou e declarou que o era. Por isso seu efeito é ex tunc $" 140$.
\end{abstract}

A questão, no entanto, é que o efeito ex tunc era considerado absoluto, ressalvadas algumas decisões isoladas, como a do Ministro Prado Kelly. Essas decisões, no entanto, fundamentavam-se na "força normativa dos fatos" e não propriamente na segurança jurídica, sob sua feição subjetiva (princípio da proteção da confiança legítima).

Outro argumento absolutamente relevante é que, de acordo com a doutrina tradicional, haveria um problema de hierarquia da Constituição Federal, que ao admitir-se a "sobrevivência" do ato ilegal, estar-se-ia sobrepondo o ato em relação à própria Constituição.

${ }^{140}$ Cf. ZA VA SCKI, Teori Albino. Eficácia das sentenças na jurisdição constitucional. São Paulo: Revista dos Tribunais, 2001.p. 48-49. 
Afirmava-se que a ordenação jurídica deve ser livre de contradição. Assim, não seria possível que duas normas jurídicas regulassem de modo diferente o mesmo fato; por exemplo, que uma norma jurídica ordenasse algo que outra norma jurídica proibisse. A liberdade de contradição seria assegurada pelo fato de as normas jurídicas serem postas em uma ordem hierárquica e ser concedida primazia à norma jurídica de grau mais elevado diante da norma jurídica classificada em inferioridade ${ }^{141}$.

Ao tratar da relação de hierarquia, Hartmut Maurer menciona:

\begin{abstract}
"A Constituição ocupa a ponta, a ela seguem as leis, os regulamentos jurídicos e os estatutos. Da ordenação hierárquica resultam duas conclusões. A primeira concerne à vinculação do legis lador com relação às normas jurídicas de grau mais elevado. $\mathrm{O}$ legis lador tem de observar a Constituição, o administrador público que expede os regulamentos deve observar as leis e a Constituição, e assim por diante. A segunda concerne à solução de colisão de normas. Quando duas normas jurídicas estão em contradição uma com a outra, porque elas regulam um fato diferentemente, então a norma jurídica de grau mais baixo é suprimida e derrogada pela norma jurídica de grau mais elevado com a consequência que ela se torna nula ou ineficaz. Isso vale tanto para o caso que a colisão acontece pela promulgação da norma jurídica inferior como para o caso de a colisão acontecer pela promulgação de norma jurídica superior. Em ambos os casos, intervém a regra de colisão. Vale o princípio: lex superior derrogat legi inferior, ${ }^{\text {, }} 4$.
\end{abstract}

Assim, pela concepção tradicional mencionada há pouco, não se admitia que um ato ilegal mantivesse seus efeitos, sob pena de malferir o princípio da supremacia da Constituição, dando-se prevalência a uma norma inferior em contrariedade com outra superior.

Somente com a entrada em vigor das Leis $\mathrm{n}^{\mathrm{o}}$ 9.784, de 29 de janeiro de 1999 (arts. $2^{\mathrm{o}}$ e 54); $\mathrm{n}^{\mathrm{o}}$ 9.868, de 11 de novembro de 1999 (art. 27) e $\mathrm{n}^{\mathrm{o}}$ 9.882, de 3 de dezembro de 1999 (art. 11) - que dispõem, respectivamente, sobre o processo administrativo da União; a Ação Declaratória de Constitucionalidade (ADC), a Ação Direta de Inconstitucionalidade (ADin); e a Arguição de Descumprimento de Preceito Fundamental -, é que passaram a se referir à segurança jurídica, quer como princípio geral da Administração Pública, de matriz constitucional, a justificar a permanência no mundo jurídico de atos administrativos

\footnotetext{
${ }^{141}$ MAURER, Hartmut. Elementos do direito administrativo alemão, p. 22.

142 Ibidem, p. 26/27.
} 
inválidos, quer como valor constitucional a ser ponderado, em determinadas circunstâncias, em cotejo com os princípios da supremacia da Constituição e da nulidade ex tunc da lei inconstitucional.

É importante observar, agora sim, que nesses textos legislativos nacionais a "segurança jurídica" é tomada predominantemente pelo seu lado subjetivo e significa, assim, "proteção à confiança".

Após a publicação dos três diplomas retromencionados, a jurisprudência do Supremo Tribunal Federal, de maneira inaugural ${ }^{143}$, sob a relatoria do Ministro Gilmar Mendes, passou a qualificar a segurança jurídica como princípio constitucional na posição de subprincípio do Estado de Direito.

Isso porque a Lei no 9.784, de 29 de janeiro de 1999, que "regula o processo administrativo no âmbito da Administração Pública Federal”, conferiu expressão, no plano infraconstitucional e no tocante ao Direito Administrativo, ao princípio da segurança jurídica em alguns de seus dispositivos. Assim o fez (a) no caput do art. $2^{\underline{o}}$, ao declarar que a "Administração Pública obedecerá, dentre outros, aos princípios da legalidade, finalidade, motivação, razoabilidade, proporcionalidade, moralidade, ampla defesa, contraditório, segurança jurídica, interesse público e eficiência”; (b) no parágrafo único desse mesmo artigo, inciso IV, ao determinar a observância, nos processos administrativos, do critério da "atuação segundo padrões éticos de probidade, decoro e boa fé"; (c) no inciso XIII, também desse parágrafo único, ao estabelecer a vedação de aplicar a fatos pretéritos nova interpretação de norma jurídica; e (d) no art. 54, ao prescrever que "o direito da Administração de anular os atos administrativos de que decorram efeitos favoráveis para os destinatários decai em 5 (cinco) anos, contados da data em que foram praticados, salvo comprovada má fé".

Surge, portanto, a correta interpretação de que a aplicação do princípio da confiança, como expressão da segurança jurídica "subjetivada", é um valor constitucional que se qualifica como subprincípio do princípio maior do Estado de Direito, ao lado e no mesmo nível hierárquico do outro subprincípio do Estado de Direito, qual seja, o da legalidade ${ }^{144}$.

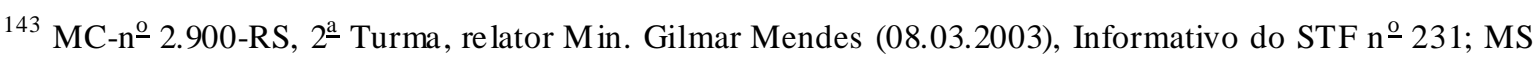
24268/MG, relator Min. Gilmar Mendes (15.03.2004), Informativo do STF no 343 e MS 22357/DF, relator Min. Gilmar Mendes, DJU de 24.5.2004.

${ }^{144}$ COUTO E SILVA, Almiro do. O princípio da segurança juríd ica (proteção à confiança) no direito público
} 
No tocante à legislação, já se mencionou que duas outras leis, também do ano de 1999, referiram-se à segurança jurídica como valor constitucional: a Lei no 9.868 (a Lei da Ação Direta de Inconstitucionalidade e da Ação Declaratória de Constitucionalidade) e a Lei $\mathrm{n}^{\mathrm{o}} 9.882$ (a Lei da Arguição de Descumprimento de Preceito Fundamental), respectivamente nos seus arts. 27 e 11 .

Ambas essas normas atribuíram ao Supremo TribunalFederal a faculdade de

"[...] o declarar a inconstitucionalidade de lei ou ato normativo, e tendo em vista razões de segurança jurídica ou de excepcional interesse social, [...] por maioria de $2 / 3$ de seus membros, restringir os efeitos daquela declaração ou decidir que ela só tenha eficácia a partir do seu trânsito em julgado ou de outro momento que venha a ser fixado".

Após a publicação dessas leis, a jurisprudência iniciou um processo de evolução na adoção do princípio da segurança jurídica em sua feição subjetiva - proteção à confiança legítima -, de sorte que, em 27 de maio de 2003, a $2^{-}$Turma do Supremo Tribunal Federal, resolvendo questão de ordem na Medida Cautelar no 2.900-3/RS, referendou por unanimidade o voto do Relator, Ministro Gilmar Mendes. Após citar trechos doutrinários de Almiro do Couto e Silva sobre o princípio da segurança jurídica como limite ao poder-dever da Administração Pública de anular seus próprios atos administrativos, o Ministro Relator conclui:

"Considera-se, hodiernamente, que o tema tem, entre nós, assento constitucional (princípio do Estado de Direito) e está disciplinado parcialmente, no plano federal, na Lei no 9.784, de 29 de jane iro de 1.999 (v.g., art. $2^{\underline{o}}$ ). Em verdade, a segurança jurídica, como subprincípio do Estado de Direito, assume valor ímpar no sistema jurídico, cabendo-lhe papel diferenciado na realização da própria idéia de justiça material. [...]"

Em face da importância a que faz jus, cabe destacar este que é um dos primeiros acórdãos do Supremo Tribunal Federal sobre a matéria, pois reconhece a segurança jurídica, entendida como proteção à confiança legítima, como princípio constitucional,

brasileiro e o direito da administração pública de anular seus próprios atos administrativos: o prazo decadencial do art. 54 da lei do processo administrativo da união (Lei no 9.784/99). $R P G E$, v. 27, n. 57, 2004a, p. 38. 
servindo, nessa condição, como limite ao poder da Administração Pública de anular seus atos administrativos, sendo oportuno descrever a situação fática a que se referem.

No caso submetido a julgamento (MC 2.900/RS), tratava-se de ação cautelar em que se pleiteava concessão de efeito suspensivo a Recurso Extraordinário interposto contra acórdão do Tribunal Regional Federal da $4^{\underline{a}}$ Região, por estudante de Direito da Universidade Federal de Pelotas que pedira transferência para o curso da Universidade Federal do Rio Grande do Sul (UFRGS). A estudante havia sido aprovada em concurso realizado pela Empresa Pública de Correios e Telégrafos para emprego naquela entidade, tendo sido contratada. Mudou, assim, seu domicílio para Porto Alegre, local do seu emprego e do curso para o qual solicitara a transferência. Negada administrativamente a transferência, contra o ato respectivo impetrou a interessada mandado de segurança, deferido por sentença proferida em dezembro de 2000, conforme excerto colacionado a seguir:

\section{“[...]}

(a) para reconhecer que a impetrante tem direito a transferir-se e a freqüentar o curso de direito na UFRGS, a partir deste semestre; (b) determinar à autoridade impetrada que imediatamente providencie a transferência da parte impetrante, permitindo que a mesma realize a matrícula, freqüente as atividades discentes e todas as demais decorrentes da sua condição de estudante, tudo nos termos da fundamentação."

Em segundo grau, a 3 ${ }^{\mathrm{a}}$ Turma do Tribunal Regional Federal da 4⿳⺈ ${ }^{\mathrm{a}}$ Região reformou a sentença, denegando o mandado de segurança. Daí o Recurso Extraordinário, manejado em outubro de 2002, e a ação cautelar para atribuir efeito suspensivo a esse recurso, uma vez que a recorrente já se encontrava prestes a concluir o curso de Direito na UFRGS. Ao conceder liminarmente o efeito suspensivo pretendido, em decisão monocrática após confirmada pela 2ª Turma, o Ministro Gilmar Mendes observou que, "no âmbito da cautelar, a matéria evoca, inevitavelmente, o princípio da segurança jurídica"145.

\footnotetext{
145 O caso guarda grande similitude com antigas decisões do Supremo Tribunal Federal, como as proferidas no RMS 13.807 (RTJ 37/248) e no RMS 17.144 (RTJ 45/589), be m como no REno 85.179 -RJ, cuja relatoria esteve a cargo do Ministro Bilac Pinto (RTJ 83/931 - DJ 01.12.77).

Cotejando-se essas decisões do STF verifica-se que todas elas tratam de situação que se consolidou em razão de provimentos jurisdicionais provisórios, afinal reformados, depois de transcorridos alguns anos de tramitação do processo. A diferença entre as mais antigas e a mais recente está na fundamentação. Enquanto a mais recente alude ao princípio da segurança jurídica, as outras limitam-se a referir que o ato judicial, depois reformado, dera causa a situação de fato e de direito que não conviria fosse inovada. No relatado pelo
} 
Resta cristalino que, embora a jurisprudência nacional, particularmente a do Supremo Tribunal Federal, já se tivesse manifestado, no passado, em favor da manutenção de atos administrativos inválidos, a despeito de ilegais, a fundamentação jurídica ainda não se baseava na "segurança jurídica subjetivada (proteção da confiança legítima)" como principal argumento para a decisão ${ }^{146}$, mas sim na força normativa dos fatos.

O acórdão do Supremo Tribunal Federal, cuja relatoria era da lavra do Ministro Gilmar Mendes, ao declarar, pela primeira vez na jurisprudência daquela Corte, que a segurança jurídica é um princípio constitucional, como subprincípio do princípio do Estado de Direito (art. 1ํ da CF), consolida a ideia de que tanto a legalidade como a segurança jurídica são princípios constitucionais que, em face do caso concreto, deverão ser sopesados e ponderados, para definir qual deles fará que a decisão realize a justiça material.

Nessa linha também se posicionou o Superior Tribunal de Justiça por meio do voto do Ministro Humberto Gomes de Barros, em que o magistrado aponta não ser a legalidade princípio único da Administração Pública; ao contrário, o princípio da legalidade deve ser compatibilizado com outros princípios, com os quais se entrelaça.

Somente após a ponderação entre os princípios incidentes é que se poderá tomar a decisão acerca da revisão ou manutenção do ato adminis trativo havido como inválido. Isso porque - como o próprio voto o revela - os fatos praticados com base em ato administrativo presumidamente válido produzem efeitos jurídicos, na medida em que, apesar de não serem protegidos pelo princípio da legalidade, têm sua eficácia protegida por outros princípios, como o princípio da boa-fé. Nessa linha é o referido voto:

“[...] Esta vitoriosa corrente jurisprudencial gerou-se de uma constatação: em tema de nulidade do ato administrativo, é necessário temperar a rigidez do princípio da legalidade formal, para que ele se coloque em harmonia com outros valores essenciais à perpetuação do Estado de Direito. O princípio da legalidade gerou outro: o do primado dos interesses públicos sobre os particulares. Este princípio, erigido em preceito maior em Dire ito Administrativo foi, desgraçadamente, levado a

\footnotetext{
Ministro Bilac Pinto, o acórdão, após mencionar as anteriores manifestações do STF sobre a matéria, concluiu pela impossibilidade de tardio desfazimento do ato administrativo, "já criada situação de fato e de direito, que o tempo consolidou".

${ }^{146}$ COUTO E SILVA, Almiro do. O princípio da segurança juríd ica (proteção à confiança) no direito público brasileiro e o direito da administração pública de anular seus próprios atos administrativos: o prazo decadencial do art. 54 da lei do processo admin is trativo da união (Lei no 9.784/99). RPGE, v. 27, n. 57, p. 50.
} 
exageros e deformações. Assim, 'os superiores objetivos da Administração' foram muitas vezes confundidos com os subalternos interesses do príncipe. O sagrado postulado, vítima de solertes fraudes, transformou-se em caldo de cultura, onde proliferaram e se desenvolveram o Fascismo e tantas outras espécies de tiranias. A necessidade de colocar freios a tão dolorosos exageros trouxe à evidência antigos valores, até então relegados ao discreto plano do Direito Privado."

E prossegue o Ministro Relator, para concluir:

\begin{abstract}
"Constatou-se que a estabilidade da ordem jurídica depende de que se prestigiem entidades de boa-fé e a segurança das relações jurídicas. Em lenta e segura evolução, a Doutrina e a Jurisprudência aproximam-se de uma solução de equilíbrio entre aqueles valores simétricos. Solução magistralmente resumida na advertência do ex-presidente da Corte Suprema Argentina Miguel Angel Bercaitz, in verbis:

'Vale notar que não se deve declarar qualquer nulidade, pela nulidade mesma, no Direito Privado. Sem prejuízo econômico ou do interesse público, deve-se manter a estabilidade do ato ou do contrato'. (Teoria General del Contrato Administrativo. 2a . ed. Depalma, p. 511)

O Legislador brasileiro, sensível à preocupação, inseriu no Direito positivo, sistema em que se condicionou a declaração de nulidade à conjunção entre a lesividade e alguns vícios" (Lei $\mathrm{n}^{-0}$ 4.717, de 20.06.1965, arts. $2^{-}, 3^{-}$e $\left.4^{-1}\right)^{147}$.
\end{abstract}

Teori Albino Zavascki remata ao afirmar que é justamente esse o quadro suposto pelo art. 27 da Lei no 9.868/1999, o de um manifesto conflito entre valores constitucionais de mesma hierarquia: de um lado, a nulidade do ato; de outro, o sério comprometimento da segurança jurídica ou de excepcional interesse social. Por força do dever de dirimi-lo, o Supremo Tribunal Federal faz prevalecer o bem jurídico que considera ser mais relevante na situação em causa, ainda que isso importe a manutenção de atos ou situações formados com base em lei que se pressupunha válida, mas que era nula. Isso é julgar, não legislar. $\mathrm{O}$ legislador cria normas para disciplinar situações futuras. O Supremo, ao aplicar o art. 27 da Lei n⿳0 9.868/1999, faz juízo de valor sobre fatos já passados" ${ }^{148}$.

Por fim, em matéria tributária, cabe destacar que o Superior Tribunal de Justiça, por meio de voto da relatora Ministra Eliana Calmon, aplicou o princípio da proteção da

\footnotetext{
${ }^{147}$ Recurso Especial no 6.518/RJ. 1⿳亠丷厂 Turma, Relator Ministro Go mes de Barros, DJ 19.9.1991, p. 134.

${ }^{148}$ Cf. ZA VA SCKI, Teori Albino. Eficácia das sentenças na jurisdição constitucional, p. 50.
} 
confiança legítima, na esfera tributária, como fundamento para que o contribuinte que pudesse incluir débitos de CPMF no REFIS IV (Lei n⿳0 11.941/2008), quando esses débitos já haviam sido incluídos em outro programa de parcelamento cujo recolhimento deu-se por oito anos. Segundo entendimento da Ministra expresso no voto exarado:

\begin{abstract}
"Se a administração identifica como correta uma determinada interpretação da norma e depois verifica não ser ela a mais adequada, tem o poder-dever de, em face da legalidade, promover a alteração de seu posicionamento. Entretanto, em respeito ao postulado da proteção da confiança legítima, deve resguardar o direito do contribuinte em relação a atos administrativos consolidados à luz de critério anteriormente adotado." 149
\end{abstract}

Portanto, as considerações anteriores revelam como se desenvolveu o princípio da proteção da confiança a partir de uma nova abordagem do princípio da legalidade e da segurança jurídica e o sopesamento dos interesses coletivos e individuais que ambos envolvem a partir da análise do caso concreto.

${ }^{149}$ REsp no $1.361 .805-P R$, Min. Eliana Calmon, Recorrente: Total Linhas Aéreas S/A. Recurso provido. v.u, data de julgamento: 18.6.2013. 


\section{CAPÍTULO 5}

\section{REQUISITOS PARA APLICAÇÃO DO PRINCÍPIO DA CONFIANÇA E ESPÉCIES DE PROTEÇÃO}

\subsection{Requisitos}

Como resta demonstrado neste estudo, o princípio da proteção da confiança legítima garante o cidadão contra modificações substanciais inesperadas, mas também em relação àqueles casos cuja permanência de certas situações jurídicas, pelo decurso do tempo ou pela prática continuada da Administração, já não autoriza a revogação ou a anulação do ato administrativo, para fazer valer uma legalidade incongruente com a confiabilidade adquirida. A Administração deve respeitar esse "estado de confiança legítima" e, ao mesmo tempo, controlar os seus atos em conformidade com o respeito à confiança dos indivíduos na ação dos órgãos estatais ${ }^{150}$.

Para que haja validamente a aplicação do princípio da confiança legítima é preciso que seja produzida uma situação de quebra da previsibilidade e boa-fé do indivíduo no tocante à atuação estatal (apta a gerar expectativas passíveis de proteção).

Nessa circunstância, a aplicação do princípio da confiança irá resultar, portanto, de uma ponderação casuística entre os interesses públicos (a requerer a preservação do princípio da legalidade) e os interesses privados envolvidos, a fim de obter um grau satisfatório de previsibilidade das ações estatais. Caso a caso, deve-se analisar qual o princípio que deverá prevalecer (legalidade versus proteção à confiança).

Da mesma forma, as alterações normativas deverão prever a existência de meios e de prazo razoável para que as alterações sejam aplicadas às situações individuais eventualmente afetadas pelas modificações.

Os requisitos ${ }^{151}$ para fazer nascer o direito à proteção da confiança legítima,

\footnotetext{
${ }^{150}$ TORRES, Heleno Taveira. Direito constitucional tributário e segurança jurídica: metódica da segurança jurídica do sistema constitucional tributário, p. 222/223.

151 DERZI, Misabel Abreu Machado. Modificações da jurisprudência: proteção da confiança, boa-fé objetiva e irretroatividade co mo limitações constitucionais ao poder judicial de tributar, p. 343.
} 
portanto, são: (a) o pressuposto fático (o Tatbestand) da confiança, ou seja, a base da confiança. Em geral, exige-se da Administração a produção de "signos externos" que, mesmo não tendo efeitos vinculantes, sejam suficientemente conclusivos para orientarem o cidadão à realização de determinada conduta produzindo-se, assim, uma situação de confiança passível de proteção; (b) a boa-fé daquele que confia, ou seja, ausência de conluio, fraude etc. Sobre esse ponto, Canaris alerta para o fato de que a confiança poderá ser um fato psíquico, positivamente constatado, ou um processo inconsciente, já que “confiar não é nada mais do que a ausência de desconfiança $[. .$.$] ninguém confia com mais$ força do que aquele que não tem consciência de sua confiança"152; (c) a confiança protegida não pode ser "interior", fruto singelo da consciência subjetiva ou subconsciência da pessoa que confia, mas ela deverá ter sido objetivada "em certa medida", por meio das disposições tomadas ou de investimentos de confiança. Novamente, vêm à tona as lições de Canaris, segundo o qual "configura pressuposto importante para o reconhecimento do direito à proteção da confiança, a disposição ou o investimento feito pela parte que confia". Assim, a confiança não merece proteção, em rigor, por si mesma, mas apenas por tornar-se 'base de comportamento daquele que confia. Por isso, a responsabilidade pela confiança, fundamentalmente, pressupõe que a confiança tenha se objetivado em uma medida qualquer por parte daquele que confia, em uma 'disposição' ou no “investimento de confiança" ${ }^{153}$; e (d) a imputabilidade, ou seja, a responsabilidade pela confiança deve ser imputável ao responsável, se houver relação direta, causal, entre o fato e as disposições ou os investimentos feitos por aqueles que confiaram ${ }^{154}$.

Ávila agrega considerações importantes para aplicação do princípio da confiança legítima ao defender uma escala de intensidade de sorte a nortear o nascimento da proteção da confiança pelo aplicador do Direito ${ }^{155}$. Em um paralelo com o direito privado, seria, para fins de usucapião, o mesmo que a posse pautada por justo título e aquela sem justo título. Enquanto na primeira hipótese exige-se umperíodo menor de posse mansa e pacífica, para reconhecimento da usucapião, na segunda requer-se um prazo maior de posse mansa e pacífica. Ambos, no entanto, resultam no reconhecimento da propriedade. A diferença está na intensidade com que um e outro caso exigem para restarem configurados.

\footnotetext{
${ }^{152}$ Cf. CANARIS, Claus-Wilhelm Die Vertrauenshaftung im Deutschen Privatrecht, p. 503.

153 Ibidem, p. 510.

154 Ibidem, p. 491.

155 ÁVILA, Hu mberto Berg mann. Segurança jurídica - entre permanência, mudança e realização no direito tributário, p. 367.
} 
Desse modo, defende-se, no tocante à base da confiança, a compensação da ausência de um dos requisitos por outro, dando margem à aplicação do princípio da confiança legítima mesmo se ausente em maior ou menor grau um deles.

Pois bem. A base da confiança traduz-se nas normas que serviram de fundamento para a (in)ação individual. Essa base tanto pode ser geral e abstrata, como uma lei, quanto individual e concreta, como um ato administrativo ou uma decisão judicial. Ela também pode ser positiva, por meio de atos voluntários e ativos, a exemplo do que ocorre com uma decisão judicial clara e precisa, com um ato administrativo concludente e portador de uma promessa ou com uma prática reiterada e uniforme da Administração ou, ainda, com um ato normativo legislativo. A base pode também ser negativa, passiva e, por vezes, involuntária, como, por exemplo, a tolerância administrativa ou a longa ausência de exercício de uma prerrogativa administrativa, cujo uso não seja submetido a prazo decadencial. O conhecimento da base da confiança capaz de gerar confiança é, portanto, o primeiro elemento do princípio da proteção da confiança ${ }^{156}$.

E, para que não se resvale no "justicialismo" ou no "ativismo judicial", Ávila aponta os requisitos para se avaliar a base da confiança, conforme arrolados a seguir: (a) grau de vinculação da base (base vinculante-base não vinculante); (b) grau de aparência de legitimidade da base (base válida-base inválida); (c) grau de modificabilidade da base (base com alta pretensão de permanência-base com baixa pretensão de permanência); (d) grau de eficácia no tempo da base (eficácia curta-eficácia duradoura); (e) grau de realização das finalidades da base (base efetiva-base não efetividade); (f) grau de indução da base (base indutora-base neutra); (g) grau de individualidade da base (base individual base geral); e (h) grau de onerosidade da base (base onerosa-base gratuita) ${ }^{157}$.

Passa-se, no item a seguir, à análise de cada um desses critérios.

\footnotetext{
${ }^{156}$ ÁVILA, Hu mberto Berg mann. Segurança jurídica - entre permanência, mudança e realização no direito tributário, p. 367.

${ }^{157}$ Ibidem, p. 367-388.
} 


\subsubsection{Critério do Grau de Vinculação da Base (Base Vinculante - Base Não Vinculante)}

Quanto maior for o grau de vinculação normativa da base normativa, maior deve ser a proteção da confiança nela depositada. Esse requisito decorre do fato de que nem todas as normas têm o mesmo grau de vinculatividade: há leis cogentes, que obrigam, assim como há leis dispositivas, que permitem; há atos administrativos com eficácia externa, dirigidos aos particulares, a exemplo dos atos normativos interpretativos, como há atos administrativos com eficácia interna, a exemplo das ordens de serviço; e assim por diante.

Em suma, admitindo o ato algum grau de disposição do particular, quanto maior for sua vinculatividade, maior será a expectativa que o cidadão deverá ter com relação ao seu futuro cumprimento, pela menor capacidade de escolha da decisão a tomar e pela menor presença de circunstância justificadora da repartição do risco na tomada de decisão ${ }^{158}$.

\subsubsection{Critério do Grau de Aparência de Legitimidade da Base (Base Válida-Base Inválida)}

Quanto maior for o grau de aparência de legitimidade da base, maior deverá ser a proteção da confiança nela depositada. Chega-se a essa regra, de um lado, por meio das próprias exigências de cognoscibilidade e de eficácia jurídica que compõem o princípio da segurança jurídica: para que o Direito possa servir de orientação para o cidadão, ele precisa poder ser conhecido e executável; para que ele seja cognoscível e minimamente eficaz, porém, é necessário que o cidadão confie na validade dos atos normativos que tenham sido objeto de publicação ou de intimação, jamais considerando-os suspeitos.

Em outras palavras, o princípio da legalidade só funcionará, e o Direito só será minimamente eficaz, se lhe for atribuída presunção de validade. Essa presunção, no entanto, cobra um preço: o cidadão que confia na validade dos atos estatais não pode,

\footnotetext{
158 ÁVILA, Hu mberto Berg mann. Segurança jurídica - entre permanência, mudança e realização no direito tributário, p. 374/375.
} 
posteriormente, ser prejudicado. É que sem presunção de validade não há confiabilidade. Sem nenhuma confiabilidade, entretanto, também não há obediência ${ }^{159}$.

O critério da aparência de validade, aliás, como todos os outros, não é nem definitivo, no sentido de necessário e suficiente para a proteção da confiança, nem tem a sua configuração isenta de dificuldades ${ }^{160}$.

Daí falar-se em aparência de legitimidade do ato, em vez de legitimidade do ato. A aparência de legitimidade depende, a seu turno, de questões vinculadas aos sujeitos do ato (quanto maior for o escalão da autoridade emanadora do ato e maior o número de sujeitos envolvidos na composição de seu conteúdo, maior será a presunção de que ele seja conforme ao Direito, pela pressuposição de que autoridades mais altas erram menos) e à forma adotada (quanto maiores forem a publicidade e a participação democrática na sua elaboração, maior será a presunção de que o ato esteja correto, pela assunção de que atos públicos não visam esconder defeitos e de que a participação de mais pessoas contribui para diminuir os vícios do ato), dentre outros elementos ${ }^{161}$.

\subsubsection{Critério do Grau de Modificabilidade da Base (Base com Alta Pretensão de Permanência-Base com Baixa Pretensão de Permanência)}

Quanto maior for o grau de permanência da base, maior deverá ser a proteção da confiança nela depositada. Isso porque há (a) atos com pretensão de permanência, como uma lei sem prazo final de vigência; (b) atos meramente provisórios, cuja eficácia definitiva depende de outro ato subsequente, como uma medida provisória ou uma decisão administrativa intermediária; e (c) atos carentes de definitividade, dada a existência de competência para a sua modificação por questões de política econômica, como alterações de tributos, que podem ter a sua alíquota modificada por meio de decreto do Presidente da República. Ora, esses atos não têm o mesmo grau de permanência - alguns nascem para

\footnotetext{
159 ÁVILA, Hu mberto Berg mann. Segurança jurídica - entre permanência, mudança e realização no dire ito tributário, p. 375/376.

${ }^{160}$ Ibidem, p. 376.

${ }^{161}$ FRITZ, Oss senbühl. Die Rücknahme fehlerhafter begünstigender Verwaltungsakte. 2. ed. Berlin: Walter de Gruyter, 1965. p. 99.
} 
durar e outros são destinados, desde o início, a uma existência provisória, quando não efêmera.

Pois bem. Por ser a aptidão de gerar confiança o critério distintivo da base, também não se pode igualar a eficácia constitutiva de confiança de um ato com pretensão de permanência com a de um ato meramente transitório e circunstancial. Isso porque, quanto maiores forem a pretensão e permanência, maior deverá ser a confiabilidade do cidadão, indo do extremo de definitividade até o extremo de efemeridade ${ }^{162}$.

O princípio da segurança jurídica deve proteger, em outras palavras, o exercício responsável da liberdade. Isso não ocorrerá se for protegida a confiança depositada em um ato que se saiba ser, ou que se deva saber ser, marcadamente transitório e, portanto, capaz de futura modificação. Nesse caso, ainda que se possa considerar existente a confiança, não haverá confiança legítima, nem, muito menos, base digna de confiabilidade capaz de permitir que se venha a alegar frustração ou surpresa: só há surpresa quando o cidadão não espera por algo que surge de inopino ${ }^{163}$.

Desse modo, será preciso verificar se a ausência de permanência não é compensada por outras qualidades da base da confiança. Em caráter excepcional, portanto, poderá haver proteção da confiança mesmo quando o particular pode contar com a sua modificação futura ${ }^{164}$.

\subsubsection{Critério do Grau de Eficácia no Tempo da Base (Eficácia Curta-Eficácia Duradoura)}

Quanto mais duradoura no tempo for a eficácia temporal da base, maior proteção merecerá a confiança nela depositada. Isso porque o passar do tempo vai reforçando a aparência de legitimidade da base, normalmente dos atos administrativos: quanto mais longa for a produção de efeitos, mais irá se desfazendo a dúvida eventualmente existente

\footnotetext{
162 ÁVILA, Hu mberto Berg mann. Segurança jurídica - entre permanência, mudança e realização no direito tributário, p. 381.

${ }^{163}$ Ibidem, p. 382.

${ }^{164}$ Ibidem, p. 383
} 
com relação à validade do ato. O tempo, aqui, "cria" ou "reforça" a confiança do particular na base normativa. Daí a assertiva escorreita de Reale de que,

\begin{abstract}
"[...] quando a inércia da Administração já permitiu se constituíssem situações de fato revestidas de forte aparência de legalidade, a ponto de gerar nos espíritos a convicção da sua legitimidade, seria absurdo que, a pretexto da eminência do Estado, se concedesse às autoridades um poderdever indefinido de autotutela" ${ }^{\prime 65}$.
\end{abstract}

A respeito disso, pode-se afirmar, de um lado, que a prática reiterada de aplicação de um ato tem uma espécie de eficácia concludente com relação à sua validade, podendo fazer que o particular aja casualmente orientado por essa prática ${ }^{166}$; de outro, essa prática faz gerar no administrado a concepção de que a Administração não irá revogar o ato. Mesmo que seja inexistente o prazo decadencial para a revisão do ato administrativo, o transcurso do tempo sem nenhum tipo de ação estatal pode comprometer o próprio direito da Administração de revisá-lo. É precisamente nesse sentido a disposição contida no parágrafo único do art. 100 do CTN, segundo o qual devem ser afastados a penalidade e os juros quando o particular confia na prática reiterada da Administração.

O essencial é que a prática continuada seja capaz de gerar no cidadão a impressão de validade do ato, de tal modo que a descontinuidade futura da produção de efeitos possa ser vista como ato de deslealdade. Desse modo, portanto, a relação entre a base da confiança e o tempo é inversamente proporcional: quanto maior for o tempo de eficácia do ato, menos forte precisará ser a base da confiança; quanto menor for o tempo de eficácia do ato, mais forte deverá ser a base da confiança ${ }^{167}$.

\footnotetext{
${ }^{165}$ REA LE, Miguel. Revogação e anulamento do ato administrativo, p. 86.

${ }^{166}$ HEY, Johanna. Steuerplannung ssicherheit als Rechtsproblem. Köln: Otto Sch midt, 2002. p. 737.

${ }^{167}$ Faz-se necessária, ainda, u ma observação. Ávila distingue duas dimensões no que se refere à proteção de situações individuais: de um lado, há a dimensão objetiva da aplicação reflexiva da segurança jurídica, revelada pela intangibilidade de situações individuais por razões objetivas decorrentes da sua consolidação fática; de outro, há a dimensão subjetiva da aplicação reflexiva da segurança jurídica, exteriorizada pela intangibilidade de situações individuais por razões subjetivas originadas do exercício da confiança. Em termos conceituais, essas duas espécies de proteção são distintas: uma coisa é manter os efeitos jurídicos de ato ilegal ou inconstitucional em razão de o longo transcurso do tempo tê-los tornados irreversíveis, pouco importando se o ato foi, ou não, praticado de boa-fé e se o particular tinha ou deveria ter conhecimento de sua ilegitimidade. Na primeira hipótese a confiança é irrelevante; na segunda ela é relevante. Daí não se poder conceitualmente confundir um caso de situação consolidada com um caso envolvendo proteção de confiança. A distinção entre ambas as situações, no entanto, não é pontual, mas, sim, continuada: a transição entre u ma e outra é semelhante à passagem do dia para a noite, em que não há dúvida a respeito da distinção entre os dois estados, embora haja incerteza no tocante ao momento exato em que se passa de um para outro. Isso ocorre
} 


\subsubsection{Critério do Grau de Realização das Finalidades da Base (Base Efetiva-Base Não}

Efetividade)

Quanto maior for o grau de realização da finalidade subjacente à regra supostamente violada, tanto maior deverá ser a proteção dos efeitos do ato inquinado de ilegal. Chega-se a essa regra pela constatação de que as exigências formais dirigidas à lei e aos atos administrativos não constituem um fim em si, mas meios para assegurar, para a maior parte dos casos, a realização de determinados fins. A exigência de lei para a instituição de um benefício fiscal, por exemplo, serve para evitar o desperdício de dinheiro público, para afastar a desigualdade e para garantir a igualdade de concorrência. A exigência de concurso para o ingresso na carreira pública funciona como instrumento destinado a evitar o preenchimento inadequado de cargos, garantir a igualdade de condições entre os concorrentes e afastar a arbitrariedade no processo de seleção.

Se assim o é, porém, quando a finalidade subjacente à regra formal for atingida, mesmo com o descumprimento do comportamento estabelecido pela sua hipótese, haverá uma razão que, conjugada as outras, poderá conduzir à manutenção do ato inválido. É o caso, por exemplo, da seleção feita para ocupar cargos de sociedade de economia mista: embora não tenha havido concurso público, o Supremo Tribunal Federal decidiu manter a contratação sob o argumento de que a seleção foi de tal forma rigorosa, e a igualdade de chances entre os candidatos com tal intensidade garantida, que não haveria sentido em anulá-la. Em outras palavras, o que o Tribunal fez foi manter o ato inquinado de invalidade porque o fim da regra foi indiretamente atingido, sem prejuízo para estabilidade geral do ordenamento jurídico ${ }^{168}$.

porque há entre a situação consolidada e a proteção da confiança um ponto de contato, que é o tempo: ele tanto funciona como fator gerador de irreversibilidade fática ou jurídica quanto como fator gerador de confiança. O transcurso do tempo vai paulatinamente legitimando a base normativa, a tal ponto que o seu destinatário, ainda que saiba do seu nascimento inválido, começa a acreditar na sua validade, pela longa e concreta produção de efeitos. Em sendo assim, embora não se deva confundir situação faticamente consolidada com confiança legítima, em casos limítrofes não se saberá exatamente se a intangibilidade será garantida por um ou por outro motivo. Sobre esse aspecto, assiste total razão a Zanella Di Pietro quando afirma que, na verdade, pode haver incidência simultânea de vários aspectos do princípio da segurança jurídica em alguns casos: "Em todas es sas situações, protege-se a estabilidade das relações jurídicas, ou seja, o princípio da segurança jurídica em seu aspecto objetivo; protege-se também a confiança do cidadão, ou seja, o princípio da segurança juríd ica em seu aspecto subjetivo ou princípio da confiança legítima; e ainda se protege a boa-fé ${ }^{167}$,"

168 ÁVILA, Hu mberto Berg mann. Segurança jurídica - entre permanência, mudança e realização no direito tributário, p. 386. 


\subsubsection{Crité rio do Grau de Indução da Base (Base Indutora-Base Neutra)}

Quanto maior for o grau de indução decorrente da base, maior deverá ser a proteção merecida pela confiança com base nela exercida. Isso porque nem todas as normas funcionam, da mesma forma, como fundamento para a ação individual: algumas exercem uma função fundante maior que outras. É o caso, por exemplo, das normas indutoras: nestas, o particular não apenas atua na esfera de ação permitida por uma legislação que estabelece apenas uma moldura para a ação, mas também age na esfera de ação estimulada por uma legislação - e, portanto, pelo Estado, que induz a ação. As normas indutoras são não apenas condições de ação, mas ainda o seu apelo e o seu objeto, e o fundamento da atividade; não são limites de atuação, mas a sua oferta e o seu modelo. Não se pode, portanto, igualar o exercício permitido de uma atuação com aquela que a induz. De fato, uma coisa é a imprevisão concernente à liberdade livremente concebida nos limites do permitido; outra, a surpresa relativa à liberdade induzidamente exercida dentro dos limites do que passou a ser obrigatório. Lá, há mera surpresa do contribuinte, decorrente da prerrogativa legislativa ou administrativa de mudar; aqui, mais que surpresa, há engano do contribuinte, decorrente de deslealdade do Poder Público; que em um dia incentiva, e em outro desconsidera ${ }^{169}$.

\subsubsection{Crité rio do Grau de Individualidade da Base (Base Individual-Base Geral)}

Quanto maior for o grau de proximidade do ato, maior deverá ser a proteção da confiança nele depositada. Isso porque há atos de eficácia individual, dirigidos a determinados cidadãos, às vezes só a estes, como termos de acordo ou contratos administrativos, e atos de eficácia geral, como leis. Como esses atos não têmo mesmo grau de individualidade, criam bases de confiança diversas. É que, sendo a aptidão para gerar confiança o critério distintivo da base, também não se pode igualar a eficácia constitutiva de confiança de um ato dirigido especificamente a um cidadão com a de um ato dirigido a

\footnotetext{
169 ÁVILA, Hu mberto Berg mann. Segurança jurídica - entre permanência, mudança e realização no direito tributário, p. 387.
} 
todos, sem nenhum elemento subjetivo. Isso porque, quanto maior for a individualidade do ato, maior deverá ser a confiabilidade do cidadão, pois maior será a "relação de confiança" estabelecida. Um ato individualizado produz no destinatário a ideia de que o direito previsto é "seu". Em suma, quanto maior for a proximidade entre o Poder Público e o cidadão, maior será a relação de lealdade que se cria, e tanto maior será o engano com a modificação posterior ${ }^{170}$.

\subsubsection{Crité rio do Grau de Onerosidade da Base (Base Onerosa-Base Gratuita)}

Quanto maior for o grau de onerosidade da base, maior deverá ser a proteção da confiança nela depositada. Chega-se a essa regra pela constatação da existência de atos que criam ônus aos particulares, como termos de acordo ou contratos administrativos que preveem cláusulas criadoras de obrigações para o particular, e de atos gratuitos, que não se submetem a condições nem criam deveres. A diferença atinente à onerosidade cria bases distintas de confiança, porque, quanto maior for a onerosidade, maior será o compromisso assumido pelo cidadão em face do Estado e, sendo as condições sinalagmáticas, tanto maior será também a persecução do interesse público. Nessa situação, deverá ser maior também a proteção da confiança depositada no Estado enquanto o particular estiver fazendo sua parte ${ }^{171}$.

A indicação dos critérios anteriores de verificação dos elementos da base da confiança demons tra que a sua configuração depende de vários elementos, e não de apenas um deles. Cada critério, como observado, depende de uma verificação gradual: a base da confiança será tanto maior quanto mais intensamente estiver presente o elemento considerado $^{172}$.

\footnotetext{
170 ÁVILA, Hu mberto Berg mann. Segurança jurídica - entre permanência, mudança e realização no direito tributário, p. 391/392.

${ }^{171}$ Ibidem, p. 392/393.

${ }^{172}$ Ibidem, loc. cit..
} 
Além, portanto, de investigar a base da confiança, cabe observar que para existir proteção da confiança é preciso que o particular tenha confiado na "base da confiança". E, para que isso ocorra, é preciso que, antes de tudo, ele tenha conhecimento da base da confiança. Aqui, nota-se a relação da exigência de confiabilidade com a exigência de cognoscibilidade do Direito: o particular precisa conhecer a base da confiança por meio da publicação ou da intimação.

A confiança, justamente porque o cidadão deve orientar-se por leis válidas e vigentes ou por atos normativos que produzam efeitos, inicia-se com a publicação da lei e com a intimação do ato ou decisão administrativa. Meros projetos de lei ou manifestações administrativas ainda não reduzidas a termo e objeto de intimação não geram confiança ${ }^{173}$.

Resta ainda mencionar outros dois requisitos: (a) o exercício da confiança; e (b) a frustração da confiança.

O exercício da confiança nada mais é senão a necessidade de que o cidadão tenha “colocado em prática" a sua confiança, por meio do exercício concreto de sua liberdade ${ }^{174}$.

A frustração da confiança, por sua vez, é igualmente um requisito necessário para aplicação do princípio em estudo, qual seja, o princípio da proteção da confiança. Isso porque essa proteção só se justifica nos casos em que o cidadão tem a sua confiança, gerada por um ato estatal anterior, frustrada por uma nova manifestação estatal posterior contraditória.

Nem toda frustração, porém, justifica a proteção da confiança. Isso porque o cidadão não tem o direito subjetivo de que a ordem jurídica permaneça sempre como está,

\footnotetext{
173 ÁVILA, Hu mberto Berg mann. Segurança jurídica - entre permanência, mudança e realização no dire ito tributário, p. 397.

174 Explica o autor que a doutrina é oscilante no que tange à exigência de que o exercício da confiança seja efetivamente um requisito para a proteção da confiança: alguns sustentam que sim; outros, que não. A jurisprudência do Supremo Tribunal Federal, pelo menos com relação ao Direito Administrativo, manifestase a favor de que deve haver atos concretos para construir, no qual se exige, para a proteção, que o particular tenha iniciado a construção (ibidem, p. 398). A questão de saber se o exercício da liberdade é, ou não, requisito indispensável para a proteção da confiança resolve-se verificando, primeiro, o tipo de estabilidade pretendida - se aquele atinente ao ordenamento jurídico como um todo, com base na face objetiva do princípio da segurança jurídica, que exige durabilidade normativa (confiabilidade por meio da permanência) e de desenvolvimento normativo estável, moderado e consistente (calculabilidade por meio da continuidade), ou aquele relativo a uma situação concreta, com base na aplicação reflexiva do princípio da segurança jurídica, que veda restrições injustificadas no exercício passado da liberdade juridicamente orientada (confiabilidade por meio da proteção da confiança); e, segundo - e como consequência -, se a estabilidade pretendida está, ou não, fundamentada nos direitos fundamentais individuais. Assim, se o problema diz respeito às exigências objetivas de permanência e continuidade do ordenamento jurídico, não se deve falar em demonstração do exercício passado da liberdade. Caso, porém, o problema se refira à intangibilidade de direitos individuais, o exercício da confiança será pressuposto para a proteção da confiança (ibidem, p. 400).
} 
em virtude da prerrogativa do Poder Legislativo de inová-la, por meio da sua liberdade de configuração democrática ${ }^{175}$.

É pertinente destacar que a frustração da confiança pode advir tanto do Poder Legislativa, mediante uma alteração legislativa brusca e sem mecanismos de transição. Pode ainda resultar do ato do Poder Judiciário, por exemplo, quando há alteração de jurisprudência consolidada, em que milhares de contribuintes confiaram e que mais tarde é modificada ${ }^{176}$. E, por fim, também a frustração pode originar-se de ato do Poder Executivo, mediante a revisão de atos administrativos tidos por ilegais ou a mudança da prática administrativa que por anos guiou o comportamento de contribuintes.

O presente trabalho abordará somente esta última hipótese, envolvendo o Poder Executivo e as práticas reiteradamente observadas pelas autoridades administrativas em matéria tributária.

Antes, contudo, cabe investigar as consequências que se ligam em decorrência da proteção da confiança legítima já que ela acaba por impor limitações ao próprio princípio da segurança jurídica.

175 ÁVILA, Humberto Berg mann. Segurança jurídica - entre permanência, mudança e realização no dire ito tributário, p. 402.

${ }^{176}$ Fatos recentes despertaram o interesse da dogmática jurídica, em especial em questões tributárias. Em junho de 2007, o Supremo Tribunal Federal enfrentou importante questão de ordem, levantad a pelo Ministro Ricardo Lewandowski, no RE n⿳ 370.682-SC, sobre a possibilidade de se concederem efeitos prospectivos à decisão que, em 15 de fevereiro de 2007, denegara o direito ao crédito "presumido" no IPI, relativo às entradas de produtos sujeitos à alíquota zero, por maioria de um voto apenas. É que essa decisão, sem ter havido qualquer mudança no texto da Constituição ou da lei, alterou entendimento anterior da mesma Corte que, no RE no 350.446-PR também do Plenário, concedera o direito ao creditamento do IPI, relativo às aquisições de insumos sujeitos à alíquota zero, em idênticas circunstâncias. Não interessa discutir a decisão em seu mérito. Interessa, apenas, que, quase cinco anos depois, a mudança de entendimento da Corte suscita a questão de ordem, que envolve princípios da alta relevância como segurança jurídica, irretroatividade, proteção da confiança e boa-fé. Pela primeira vez, foi posta a indagação em matéria tributária. Sabe-se que, durante o período em que vigorou o entendimento anterior, favorável aos contribuintes e, agora, superado pelo Tribunal, cerca de sessenta recursos extraordinários encaminhados àquela Corte Constitucional, por causa dele e nele assentados, foram julgados monocraticamente por vários ministros do próprio Tribunal então convencidos de sua definitividade. Convém esclarecer que mu itos contribuintes, confiantes na posição aparentemente pacificada pela Suprema Corte brasileira, em especial aqueles que obtiveram referidas decisões monocráticas em seu favor, efetivamente se creditaram do imposto, registrando os créditos em seu balanço, na forma autorizada por aquela jurisprudência que viria a ser modificada posteriormente. Entretanto, ao apreciar a questão de ordem, levantada pelo Ministro Lewandowski, a Corte não reconheceu, no caso em tela, confiança a ser protegida, nem direito à segurança ou à irretroatividade da nova decisão, ao argumento de que nenhuma sentença anterior, relativa à alíquota zero, chegara a transitar em julgado, embora quase cinco anos tives sem transcorrido. Isso significa que, ao negar efe itos ex nunc, meramente pros pectivos à nova decisão, a Corte consentiu com os efeitos retroativos, ex tunc, da nova decisão, que deverá alcançar os fatos geradores ocorridos nos últimos cinco anos, cobrando-se o tributo devido com elevados acréscimos, inclusive multas e penalidades pecuniárias (DERZI, Misabel Abreu Machado. Modificações da jurisprudência: proteção da confiança, boa-fé objetiva e irretroatividade como limitações constitucionais ao poder judicial de tributar, p. 205/206). 
Sobre a questão apontada, Ávila afirma que o princípio da proteção da confiança é diferenciado do princípio da segurança jurídica pelos seguintes critérios ${ }^{177}$ : (a) âmbito normativo - enquanto o princípio da segurança jurídica diz respeito ao ordenamento jurídico como um todo, focando o âmbito macrojurídico, o princípio da confiança legítima relaciona-se com um aspecto normativo do ordenamento jurídico, enfatizando um âmbito microjurídico; (b) âmbito pessoal - enquanto o princípio da segurança jurídica representa uma norma objetiva, não necessariamente vinculada a um sujeito específico, o princípio da confiança legítima protege o interesse de uma pessoa específica; (c) nível de concretização - enquanto o princípio da segurança jurídica refere-se, primordialmente, ao plano abstrato, o princípio da confiança legítima pressupõe o nível concreto de aplicação; (d) amplitude subjetiva de proteção - enquanto o princípio da segurança jurídica serve de instrumento de proteção de interesses coletivos, o princípio da confiança legítima funciona como meio de proteção de interesse(s) individual(is); (e) protetividade individual - enquanto o princípio da proteção da segurança jurídica é neutro com relação ao interesse dos cidadãos, podendo tanto ser usado em seu favor quanto em seu desfavor, o princípio da proteção da confiança só é utilizado com a finalidade de proteger os interesses daqueles que se sentem prejudicados pelo exercício passado de liberdade juridicamente orientada ${ }^{178}$.

\subsection{Espécies de Proteção}

De acordo com Canaris, há duas espécies de responsabilidade decorrentes da proteção da confiança. Há, assim, a responsabilidade pela confiança positiva e a responsabilidade pela confiança negativa. Essa diferenciação toma como critério o interesse positivo ou negativo, estabelecendo-se as alternativas: (a) a positiva caracterizase por ser a esfera jurídica daquele que confia delimitada e garantida como se o fato, em que confiou e por ele pressuposto, realmente existisse. $\mathrm{Na}$ verdade, trata-se de uma proteção positiva porque a confiança demonstrada é prestigiada e suas consequências são "efetivadas" pelo ordenamento; (b) a negativa não considera existente o fato em que se

177 ÁVILA, Hu mberto Berg mann. Segurança jurídica - entre permanência, mudança e realização no dire ito tributário, p. 362/363.

${ }^{178}$ CALMES, Sylvia. Du principe de protection de la confiance légitime en droits allemand, communautaire et français, p. 167-171. 
confiou, ele será desconsiderado, mas garante-se àquele que confiou uma indenização por danos. Essa a proteção negativa. A primeira costuma ter efeitos mais completos e depende de certa esquematização, já a segunda tem abrangência mais restrita, pois alcança tão somente os investimentos efetivamente feitos por aquele que confia ${ }^{179}$.

As espécies de proteção ora apontadas estão diretamente ligadas àquilo que a sociedade, por meio do ordenamento, ou pelo próprio Poder Judiciário, entende deva ser protegido e em que medida.

É que a proteção da confiança legítima não pode levar nunca a uma inadvertida "socialização dos prejuízos" na área da responsabilidade do indivíduo autônomo no tocante à sua privacidade ${ }^{180}$.

Assim, são colocados limites que podem resultar ainda da avaliação de todos os demais aspectos envolvidos, necessários para mensurar o que será digno de proteção em termos de confiança, e em que medida. Tudo isso porque o princípio da proteção da confiança legítima assume intensidades diversas em diferentes áreas, ramos jurídicos, relações concretas de coordenação ou de alta dependência, sendo de diferente consideração no que concerne a cada um dos Poderes do Estado.

Em remate, conclui-se que para a configuração do princípio da confiança legítima será necessário investigar (a) a base da confiança, isto é, se o ato era passível de despertar confiança no administrado; (b) a boa-fé (ausência de fraude, conluio etc.), lembrando que ninguém confia mais do que aquele que não sabe que confia; (c) os investimentos de confiança, ou seja, é preciso que tenham ocorrido atos concretos cujos efeitos serão afetados se não houver a proteção; (d) a imputabilidade revelada pela relação direta entre o responsável pela confiança gerada e o prejudicado.

Sobre o item (a) mencionado no parágrafo anterior - que trata sobre a base da confiança -, Ávila enumera critérios que, em uma avaliação gradual, auxiliarão a definir se a base é digna de confiança ou não. Em síntese, os critérios serão: (a.1) grau de vinculação da base; (a.2) grau de aparência de legitimidade da base; (a.3) grau de modificabilidade da base; (a.4) grau de eficácia no tempo da base; (a.5) grau de realização das finalidades da

\footnotetext{
${ }^{179}$ Cf. CA NARIS, Claus-Wilhelm. Die Vertrauenshaftung im Deutschen Privatrecht, p. 491.

${ }^{180}$ DERZI, Misabel Abreu Machado. Modificações da jurisprudência: proteção da confiança, boa-fé objetiva e irretroatividade co mo limitações constitucionais ao poder judicial de tributar, p. 400.
} 
base; (a.6) grau de indução da base; (a.7) grau de individualização da base; (a.8) grau de onerosidade da base ${ }^{181,182}$.

No campo dos mecanismos de aplicação do princípio da confiança legítima, viu-se que a proteção pode ser positiva, com a manutenção dos efeitos do ato ilegal, ou, negativa, neste último caso cabendo o ressarcimento dos danos sofridos.

Lembrou-se, por fim, a necessidade de ponderação dos interesses envolvidos para que a aplicação do princípio da confiança legítima não resulte em uma "socialização" inadvertida dos prejuízos oriundos da responsabilidade de um único indivíduo ou grupo de indivíduos.

Feitas essas considerações, passa-se à análise dos atos do Poder Executivo, em especial as práticas reiteradamente observadas pelas autoridades administrativas em matéria tributária.

181 Os critérios aqui mencionados foram apontados no subtítulo 5.1 - Requisitos, e examinados, respectivamente, em 5.1 a 5.8, no início deste capítulo.

182 ÁVILA, Hu mberto Berg mann. Segurança jurídica - entre permanência, mudança e realização no dire ito tributário, p. 367-388. 


\section{CAPÍTULO 6}

\section{PROTEÇÃO DA CONFIANÇA LEGÍTIMA NA ATUAÇÃO DO PODER EXECUTIVO}

Na esfera do Poder Executivo, a atuação da Administração deve ser leal, séria e justificada, de um lado, e respeitosa relativamente ao exercício dos direitos fundamentais, de outro. No contexto desse desenho de atuação deve ser solucionada a questão de saber se a Administração pode anular, desde o início, ou revogar, para frente, atos normativos, atos administrativos ou, mesmo, práticas administrativas que tenham criado alguma vantagem para os contribuintes ${ }^{183}$.

O principal problema associado à revisão administrativa diz respeito à atuação administrativa que cria vantagens e é revestida de alguma invalidade.

Em sendo o ato ilegal, surge a questão de saber se ele deve ou pode ser anulado ou revogado, tendo em vista a afirmação geral de que os atos administrativos ilícitos não geram qualquer tipo de proteção, salvo quando tiver transcorrido eventual prazo legal decadencial para o seu desfazimento ${ }^{184}$.

Consoante a evolução jurisprudencial e a doutrina têm demonstrado, em circunstâncias excepcionais, também os atos ilícitos são dignos de proteção pela eficácia reflexa do princípio da proteção da confiança legítima, pois, como os atos administrativos se revestem de força normativa, também a confiança daqueles que acreditaram na sua aparência de legitimidade deve ser protegida ${ }^{185}$.

\footnotetext{
183 ÁVILA, Hu mberto Berg mann. Segurança jurídica - entre permanência, mudança e realização no direito tributário, p. 443.

184 MUCKEL, Stefan. Kriterien des verfassungsrechtlichen Vertrauensschutzes bei Gesetzesänderungen. Berlin: Duncker und Hu mblot, 1989. p. 54.

185 Inicialmente a doutrina e a jurisprudência entendiam que um ato contrário à lei não podia produzir qualquer efeito: ad miti-lo seria violar não apenas o princípio da legalidade, co mo ta mbém o da igualdade. Em momento posterior essa compreensão foi fortalecida pelo argumento de que, ao se preservarem os efeitos de atos ilícitos, estar-se-ia também violado o princípio do interesse público. As antigas Súmulas do Supremo Tribunal Federal seguiram esse entendimento: a Súmula nº 473 prevê que a Administração pode anular os seus próprios atos quando eivados de vícios que os tornem ilegais, porque deles não se originam dire itos, ou revogá-los, por motivo de conveniência ou oportunidade, respeitos apenas os direitos adquiridos; e a Súmula no 346 prevê que a Administração Pública pode declarar a nulidade de seus próprios atos. Essas duas Súmulas, conjugadas, demonstram que a jurisprudência encampava o "princípio da livre anulação dos atos
} 
Essa mudança de perspectiva, contudo, foi apenas parcial já que a confiança do cidadão é avaliada relativamente ao ato administrativo, em especial para comprovar se ele era, ou não, capaz de gerar confiança. Nesse sentido, o poder irrestrito de revisão dos atos administrativos começou a enfrentar restrições apenas no tocante aos efeitos de atos cuja aparência de legalidade, somada à ausência de má-fé ou de negligência do destinatário, era capaz de gerar confiabilidade. Se a ilicitude é intensa ou evidente, o ato administrativo deve ser anulado ${ }^{186}$.

Infere-se, portanto, que podem ser delimitados três tipos de atuação do Poder Executivo: (a) atuação administrativa abstrata e geral, por meio dos atos normativos; (b) atuação individual e concreta; e (c) a prática administrativa.

\subsection{Atuação Administrativa Abstrata e Geral - Atos Normativos}

A Administração utiliza-se com frequência de atos normativos, como atos normativos interpretativos e pareceres normativos, que indicam a sua posição a respeito de determinada matéria. À diferença dos atos administrativos, os atos normativos são manifestações gerais e abstratas, dirigidas, pois, a um número indeterminado de situações e de pessoas. Quando o ato normativo é contrário aos interesses do contribuinte, este pode insurgir-se contra a sua aplicação, recorrendo ao Poder Judiciário e sustentando a sua ilegalidade. O problema ocorre quando o contribuinte pretende usar o ato normativo em seu benefício e não logra êxito em razão de alguma mudança administrativa. Essa mudança pode ocorrer simplesmente porque a Administração modifica o mérito do seu entendimento ou porque entende que a sua posição anterior era ilegal e, com isso, prejudica

\footnotetext{
administrativos ilegais" (Grundsatz der freien Rückname rechtswidriger Verwaltungsakte). Em razão disso, não haveria nenhum tipo de proteção decorrente dos direitos fundamentais, como observa Püttner: "nenhum direito fundamental à fruição de vantagens ilícitas" (PÜTTNER, Günter. Vertrauensschutz im Verwaltungsrecht. VVDStRL, Berlin/New York, Heft 32, Walter de Gruyter, 1974. p. 208.). Em sentido similar, mas com moderação: BAPTISTA, Patrícia. A tutela da confiança leg ítima como limite ao exercício do poder normativo da ad min istração pública - a proteção às expectativas legítimas dos cidadãos como limite à retroatividade normativa. Revista de Direito do Estado (RDE), Rio de Janeiro, n. 3, p. 155-181, 2006, p. 180.

${ }^{186}$ OSSENBÜHL, Fritz. Die Rücknahme fehlerhafter begünstigender Verwaltungakte. 2. ed. Berlin: Walter de Gruyter, 1965. p. 27.
} 
aqueles contribuintes que agiram com base no ato normativo revisado, com relação a atos passados ou mesmo com referência a atos futuros ${ }^{187}$.

Nesse quadro, é preciso saber se pode haver proteção da confiança relativamente a atos normativos. A principal objeção que pode ser levantada aqui acerca dessa proteção diz respeito à falta de vinculatividade: como no Direito Tributário vigora o princípio da legalidade, os atos provenientes da Administração possuiriam função apenas secundária e vinculada à lei.

Desse modo, quem confia em um ato normativo sabe ou deveria saber que ele não merece confiança e, sendo assim, não pode futuramente alegar frustração da confiança caso seja considerado ilegal.

Embora a falta de vinculatividade seja elemento diminuidor da protetividade da confiança, é preciso fazer algumas diferenciações atinentes aos atos normativos, já que eles não têm uma única e idêntica função.

Há atos normativos que restringem competências administrativas discricionárias ou preenchem conceitos jurídicos indeterminados, mesmo no Direito Tributário. Como já decidiu o Supremo Tribunal Federal, compete à lei estabelecer os parâmetros legais da obrigação tributária, ficando os atos normativos da Administração, no caso de competências cujo exercício dependa de prerrogativas técnicas, encarregados de definir, de acordo com aqueles parâmetros, os sentidos vinculantes ${ }^{188}$.

Pois bem. Esses atos normativos atuam, por assim dizer, "dentro da lei”, e, por isso, têm vinculação externa ${ }^{189}$. Embora esses atos não sejam enquadráveis na categoria de atos normativos primários, apresentam grau de vinculatividade distinto, já que definem o exercício de competências ou concretizam conceitos legais. Desse modo, a Administração até pode revisá- los, ou porque modificou o entendimento, ou porque passou a considerá-los ilegais, no entanto, ela não pode atingir fatos ocorridos ainda na sua vigência, pois isso violaria o princípio da proteção da confiança legítima e também a exigência de legalidade.

Da mesma forma, há atos normativos que preenchem padrões legais massificados. Ora, esses atos normativos, à exceção dos casos em que sejam evidentemente irrazoáveis, igualmente se situam dentro da lei cujo padrão visam concretizar. A Administração,

\footnotetext{
${ }^{187}$ HEY, Johanna. Steuerplannung ssicherheit als Rechtsproblem, p. 655.

${ }^{188}$ RE n. 343.446, Tribunal Pleno, Rel. Min. Carlos Velloso, DJ 4.4.2003.

${ }^{189}$ HEY, Johanna. Op. cit., p. 660.
} 
igualmente, pode modificá-los, mas não pode atingir os contribuintes que intensamente dispuseram dos seus direitos de liberdade e de propriedade com base neles, sob pena de violar o princípio da proteção da confiança e a exigência de legalidade ${ }^{190}$.

O fato de os atos normativos da Administração não possuírem vinculatividade não afasta a possibilidade de haver proteção da confiança legítima, quando a exigência de vinculação da Administração aos seus próprios atos e os direitos fundamentais assim o exigirem. É preciso referir que a própria função dos atos normativos reforça o dever de proteção da confiança que o contribuinte neles depositou: esses atos, que podem ser modificados pela Administração a qualquer tempo, também possuem presunção de validade, e, embora o contribuinte possa se insurgir pela via judicial contra aqueles, não pode deixar de ordinariamente cumpri-los.

Se o contribuinte pudesse simplesmente desconsiderar esses atos, a sua função de orientar a aplicação das normas tributárias e reduzir a insegurança de aplicação ficaria totalmente prejudicada ${ }^{191}$.

As considerações tecidas conduzem, de um lado, à conclusão de que a contrapartida da funcionalidade dos atos normativos é a proteção da confiança dos contribuintes cujas disposições foram baseadas na presunção da sua validade. De um lado, os atos normativos funcionam como instrumentos garantidores de segurança de orientação e, precisamente por isso, não podem deixar de proteger a confiabilidade inerente ao seu próprio funcionamento. De outro lado, porém, induzem à conclusão de que os contribuintes não têm direito a pleitear a manutenção da aplicação passada desses atos normativos senão depois de terem efetivamente exercido os seus direitos de liberdade e de propriedade com base neles. $\mathrm{O}$ entendimento de que o contribuinte poderia pleitear, inclusive para o futuro, a manutenção do ato normativo ilegal, independentemente de ter atuado com base nele, entraria em rota de colisão com a exigência de legalidade tributária ${ }^{192}$.

É precisamente nessa direção que o art. 146 do CTN estabelece que a mudança de orientação da Administração só tem eficácia com relação aos casos futuros, não alcançando, portanto, os casos passados. Embora esse dispositivo pressuponha a validade do ato normativo modificado, a eficácia reflexa do princípio da segurança jurídica protege

\footnotetext{
190 ÁvILA, Hu mberto Berg mann. Segurança jurídica - entre permanência, mudança e realização no direito tributário, p. 448/449.

${ }^{191}$ HEY, Johanna. Steuerplannungssicherheit als Rechtsproblem, p. 672-673/681.

192 Á VILA, Hu mberto Berg mann. Op. cit., p. 450/451.
} 
aqueles que atuaram com base na presunção da validade antes de sua modificação. Torres, nesse aspecto, é enfático ao afirmar que, de fato, se o contribuinte acreditou na palavra da Administração firmada no lançamento tributário notificado, não poderá ficar sujeito a eventuais alterações de critérios jurídico, a pretexto de erro na interpretação ${ }^{193}$.

\subsection{Atuação Administrativa Individual e Concreta - Atos Administrativos}

A atuação da Administração, em vez de geral e abstrata, pode ser individual e concreta, isto é, dirigida a determinados contribuintes em certas situações. Como já afirmado, a protetividade da confiança depende de uma articulação entre vários critérios, destacando-se, relativamente à atuação do Poder Executivo, os seguintes: (a) aparência de legitimidade do ato; (b) indução; (c) individualidade; (d) onerosidade; e (e) durabilidade.

Esses elementos poderão compensar a ilicitude da base da confiança: quanto maiores forem a aparência de legitimidade do ato, a influência comportamental dela decorrente, a proximidade com o Estado, a onerosidade gerada pela sua aplicação e a durabilidade de sua eficácia no tempo, tanto maiores serão as razões para a sua manutenção. Os elementos em questão compensam a ilicitude da base da confiança ${ }^{194}$.

Os atos administrativos individuais, dirigidos a determinados contribuintes, criam uma "relação de confiança", na medida em que conotam uma "pessoalidade". A maior proximidade entre o Poder Público e o cidadão também instaura um compromisso entre eles e, por consequência, gera um dever de lealdade: o descumprimento de um compromisso é causa de deslealdade, a seu turno, violadora do princípio da moralidade administrativa $^{195}$.

Dentre os atos administrativos, deve-se destacar a consulta administrativa, regulada pelo Decreto n⿳⺈ 70.235/1972. O contribuinte pode, diante de uma situação concreta, formular consulta perante a Administração Tributária quando houver dúvida relativamente

193 TORRES, Ricardo Lobo. Limitações ao poder impositivo e segurança jurídica. In: MARTINS, Ives Gandra da Silva (Org.). Limitações ao poder impositivo e segurança jurídica. São Paulo: RT/CEU, 2007. p. 70.

194 ÁVILA, Humberto Bergmann. Segurança jurídica - entre permanência, mudança e realização no direito tributário, p. 453.

195 Ibidem, p. 453/454. 
à incidência de tributo. Se não houver inadequação da descrição da situação de fato pelo contribuinte, a resposta à consulta obrigará a Administração: o caráter preventivo da consulta fiscal deve colocar o consulente em estado de certeza jurídica, conferidora de segurança. Não fosse assim, a consulta perderia totalmente a sua função de diminuir o risco tributário da operação e garantir calculabilidade à atuação administrativa.

No contexto da mudança administrativa, aqui examinada, o problema de segurança envolvendo a consulta não surge quando a resposta dada é cumprida pela Administração, mas, em vez disso, quando esta última revê o entendimento manifestado, quer por alterar sua posição anterior, quer por entender que a posição antes externada era ilegal. Nesses casos, os mesmos argumentos antes apresentados para justificar a proteção da confiança relativamente aos atos administrativos surgem no tocante à consulta: se o contribuinte dispôs, de maneira significativa, dos seus direitos de liberdade e de propriedade e há um nexo de causalidade entre os atos de disposição e a eficácia tributária decorrente da consulta, no sentido de que a resposta a esta foi decisiva para a atuação do contribuinte, deve haver proteção da confiança nela depositada ${ }^{196}$.

\subsection{Prática Administrativa}

$\mathrm{Na}$ atuação administrativa abstrata e geral, pode ocorrer que a Administração não tenha editado formalmente um ato administrativo, todavia tenha, durante um período, tornado visível seu entendimento geral sobre determinada matéria.

Os argumentos utilizados para justificar a proteção excepcional da confiança relativamente aos atos normativos (abstratos e gerais) serve para explicar a sua garantia no que tange à prática administrativa.

Também nesta hipótese - ainda que mais excepcionalmente, dada a falta de formalização e de publicação, que produzem maior confiabilidade à base normativa - pode haver proteção da confiança do contribuinte, desde que, porém, tenha havido, da parte deste, disposição dos seus direitos de liberdade e de propriedade com base na prática administrativa.

${ }^{196}$ HEY, Johanna. Steuerplannungssicherheit als Rechtsproblem, p. 672-673/681. 
Essa proteção decorre do fato de que, embora sem uma manifestação pontual inequívoca, o conjunto de atos administrativos vai, ao longo do tempo, consolidando um entendimento administrativo acerca de determinado assunto.

Esse entendimento, ainda que exteriorizado de forma diferente, também serve de base da confiança e, como tal, pode - presentes os requisitos já mencionados no item 5.1 do capítulo anterior - ensejar a proteção do princípio da confiança legítima ${ }^{197}$.

Daí por que esse assunto vem tratado no art. 100, inciso III, do CTN e a ele são aplicadas as benesses do parágrafo único do mesmo dispositivo, assunto a ser abordado mais detidamente no próximo capítulo.

197 Á VILA, Hu mberto Berg mann. Segurança jurídica - entre permanência, mudança e realização no direito tributário, p. 452. 


\section{CAPÍTULO 7}

\section{APLICAÇÃO DO ARTIGO 100 DO CÓDIGO TRIBUTÁRIO NACIONAL E PRINCÍPIO DA CONFIANÇA LEGÍTIMA}

Conforme salientado, este capítulo abordará os atos do Poder Executivo e sua relação com o princípio da confiança legítima, em especial as práticas reiteradamente observadas pelas autoridades administrativas em matéria tributária, referidas pelo art. 100, inciso III, do CTN.

$\mathrm{O}$ artigo em comento dispõe:

"Art. 100. São normas complementares das leis, dos tratados e das convenções internaciona is e dos decretos:

I - os atos normativos expedidos pelas autoridades administrativas;

II - as decisões dos órgãos singulares ou coletivos de jurisdição administrativa, a que a lei atribua eficácia normativa;

III - as práticas reiteradamente observadas pelas autoridades administrativas;

IV - os convênios que entre si celebrem a União, os Estados, o Distrito Federal e os Municípios.

Parágrafo único. A observância das normas referidas neste artigo exclui a imposição de penalidades, a cobrança de juros de mora e a atualização do valor monetário da base de cálculo do tributo.” (sem grifo no original)

$\mathrm{O}$ art. 100 do CTN trata das normas complementares e sua referência pelo art. $96^{198}$ do mesmo dip loma revela que elas também fazem parte da "legislação tributária".

Adverte Schoueri ${ }^{199}$ que, antes de censurar a possibilidade de confusão gerada pelo legislador ao utilizar a expressão "normas complementares", cujo vocábulo é muito próximo ao de "lei complementar", deve-se ter em mente que o Código foi escrito quando

198 “Art. 96. A expressão 'legislação tributária' compreende as leis, os tratados e as convenções internacionais, os decretos e as normas complementares que versem, no todo ou em parte, sobre tributos e relações jurídicas a eles pertinentes." (sem grifo no original).

${ }^{199}$ SCHOUERI, Luís Eduardo. Direito tributário. São Paulo: Saraiva, 2011.p. 114/115. 
nem sequer existia a espécie das leis complementares e, assim, é descabida qualquer crítica dessa natureza.

De todo modo, como fazem parte da "legislação tributária", a doutrina classifica as normas complementares previstas nos incisos do art. 100 do CTN como fontes secundárias do Direito Tributário.

\subsection{Artigo 100, Inciso III, do Código Tributário Nacional - Práticas Administrativas}

Dentre as normas complementares, ganha destaque para a presente dissertação o já mencionado inciso III do art. 100 do CTN, que versa sobre "as práticas reiteradamente observadas pelas autoridades administrativas", e sobre o qual grande parcela da doutrina afirma tratar-se do reconhecimento do "costume administrativo" como fonte do direito tributário.

Ao compulsarem-se os Trabalhos da Comissão Especial do Código Tributário Nacional $^{200}$, é possível identificar, de fato, que a norma insculpida no inciso III do artigo em comento prestigia o "costume administrativo" como fonte secundária do Direito Tributário.

Nos Trabalhos da Comissão Especial do Código Tributário Nacional foram compilados o Projeto de Código Tributário Nacional e o Anteprojeto de autoria do Professor Rubens Gomes de Sousa, que serviu de base aos trabalhos da Comissão Especial do Código Tributário Nacional. O volume ainda contempla as sugestões oferecidas ao Anteprojeto e, ao final, o relatório da Comissão.

Dispunha o Anteprojeto, no Capítulo II - Dos atos administrativos de caráter normativo -, notadamente nos arts. 109, 110 e 112, que:

“Art. 109. Completam a legis lação tributária, dentro dos limites fixados no presente Capítulo, os seguintes atos administrativos versando, no todo ou em parte, sobre a matéria referida no art. $1^{\stackrel{0}{ } \text { : }}$

$[\ldots]$

${ }^{200}$ TRA BA LHOS DA Co missão Especial do Código Tributário Nacional. Rio de Janeiro: IBGE, 1954. 
III. As práticas, métodos, processos, usos e costumes de observância reiterada por parte das autoridades administrativas, desde que não sejam contrárias à legis lação tributária ou à jurisprudência firmada do Poder Judic iário.

Art. 110.

Parágrafo único. A estrita observância dos atos administrativos referidos neste artigo, quando invocada como matéria de defesa dos contribuintes ou terceiros a quem aproveite, excluirá a imposição de qualquer penalidade, ressalvada apenas a cobrança de juros de mora, nos termos do $\S \S 1^{\circ}$ e $2^{-}$do art. 106.

[...]

Art. 112. As práticas, métodos, processos, usos e costumes referidos na alínea III do art. 109, ainda que não reconhecidos expressamente por qualquer dos atos administrativos referidos nas alíneas I e II do mesmo artigo, desde que se limitem a fixar a interpretação da legislação tributária, e não importem direta ou indiretamente na sua ampliação, restrição ou ab-rogação, poderão ser invocados pelos contribuintes ou terceiros a quem aproveitem, nos mesmos termos e com os mesmos efeitos indicados no parágrafo do art. 110."

Note-se que o art. 109, inciso III - hoje o art. 100, inciso III - do CTN afirmava que “as práticas, métodos, processos, usos e costumes" de reiterada observância pelas autoridades administrativas eram espécie tributária. Embora os quatro últimos vocábulos tenham sido suprimidos na versão aprovada do Código Tributário Nacional, observa-se que o emprego das palavras no anteprojeto e, sobretudo, a anotação prevista no art. 112, denotam que a intenção do legislador foi exatamente inserir entre as fontes tributárias a prática, ainda que não positivada no ordenamento.

De acordo com Schoueri ${ }^{201}$, o dispositivo em questão desmente aqueles que acreditem que o costume não possa ser incluído entre as fontes do Direito Tributário. $\mathrm{O}$ costume administrativo, desde que evidenciado, é "norma complementar", merecendo a proteção do parágrafo único do art. 100 do CTN.

A propósito do termo “costume”, De Plácido e Silva ${ }^{202}$ registra:

“[...] derivado do latim consuetudo, designa o vocábulo tudo o que se estabelece por força do hábito ou do uso. Embora se procure fazer distinção entre uso e costume, tecnicamente, são expressões que se revelam equivalentes, aplicando-se indistintamente como sinônimos.

${ }^{201}$ SCHOUERI, Luís Eduardo. Direito tributário, p. 116.

202 DE PLÁ CIDO E SILVA, Vieira. Vocabulário jurídico. 12. ed. Rio de Janeiro: Forense, 1996. v. I. 
Entretanto, costume aplica-se mais especialmente ao procedimento particular das pessoas, em cujo sentido se dizem bons e maus costumes, enquanto o uso, em acepção jurídica, mais se toma pela norma geral ou pela regra habitualmente em voga em certo local. Não obstante, na tecnologia jurídica, costume vem mostrar o princípio ou a regra não escrita que se introduziu pelo uso, com o consentimento tácito de todas as pessoas que admitiram a sua força como norma a seguir na prática de determinados atos."

José Roberto Marques ${ }^{203}$ afirma que a doutrina aponta a necessidade, para caracterização do costume, de dois elementos: um de ordem material, objetiva, que se identifica com "o fato da repetição constante e generalizada de certos atos"; outro, psicoló gico, consistente na "convicção de que esses atos correspondam à execução de uma obrigação jurídica".

É de Ulpiano a frase: “mores sunt tacitus consensus populi longa consuetudine inveteratus", isto é, os costumes são o tácito consenso do povo, inveterado por longo uso $^{204}$.

No Direito Administrativo, o costume tem um papel relevante, na medida em que as práticas administrativas não se acham, ainda, inteiramente disciplinadas pela legis lação. Faz-se oportuna a transcrição, a esse título, do ensinamento ministrado por Hely Lopes Meirelles ${ }^{205}$ :

\begin{abstract}
"No Dire ito Administrativo Brasileiro o costume exerce ainda influência, em razão da deficiência da legislação. A prática administrativa vem suprindo o texto escrito, e, sedimentada na consciência dos administradores e administrados, a praxe burocrática passa a suprir a lei, ou atua como elemento informativo da doutrina".
\end{abstract}

Para Eduardo Sabbag ${ }^{206}$, a norma insculpida no art. 100, inciso III, do CTN trata da praxe administrativa, marcada pela adoção de procedimentos de observância reiterada pela Administração, desde que não colidam com a jurisprudência firmada pelo Poder Judiciário. Segundo o autor, o costume pressupõe dois elementos: (a) uso (elemento externo, de

\footnotetext{
${ }^{203}$ MARQUES, José Roberto. Costume. Revista de Direito Privado, v. 22, abr. 2005, p. 153.

${ }^{204}$ Ibidem, p. 153.

${ }^{205}$ MEIRELLES, Hely Lopes. Direito administrativo brasileiro. São Paulo: Malheiros, 2003. p. 45.

${ }^{206}$ SABBA G, Eduardo. Manual de direito tributário. São Paulo: Saraiva, 2009. p. 562/563.
} 
observância constante, uniforme, pública e geral); e (b) opinião de necessidade (convicção generalizada de que a observância da norma costumeira é uma necessidade jurídica).

Dessa forma, aplica-se o costume administrativo em matéria tributária quando, por exemplo, as autoridades fiscais interpretam reiteradamente uma norma jurídica em determinado sentido, fazendo que o sujeito passivo creia que, ao seguir aquele entendimento, está agindo corretamente.

Costume administrativo é "a prática observada reiteradamente pela administração pública", sintetiza Bernardo de Moraes ${ }^{207}$.

Observe-se que essa dicção é muito próxima do próprio art. 100, inciso III, do CTN, segundo o qual são consideradas normas complementares as práticas reiteradamente observadas pelas autoridades administrativas.

Ao comentar o disposto no referido inciso - práticas das autoridades -, Aliomar Baleeiro considera ser boa a interpretação que resulta da antiga, iterativa e pacífica aplicação da lei sob determinada diretriz pelo próprio Fisco. Assim, se as autoridades deram sentido uniforme a uma disposição, entende-se ser essa inteligência a mais compatível com o texto ${ }^{208}$.

Conforme adverte Heleno Torres, a noção de "prática reiteradamente observada pelas autoridades administrativas" mostra aparente dificuldade para a sua adequada compreensão, especialmente sobre quantas práticas seriam suficientes a tanto - a estabilidade da supressio. Seja como for, o que importa é o acatamento sucessivo dessas práticas pela autoridade fiscal, quer pela atuação do contribuinte seguindo determinado modelo de agir, sempre em conformidade com a lei - ainda que em uma expectativa de confiança legítima -, em uma prática conhecida pelas autoridades e admitida; quer pela ação direta do Fisco, de acordo com uma específica linha interpretativa ou dando aplicação e tratamento fiscal a certa prática cuja reiteração confere-lhe força de "fonte do direito tributário", com equivalência aos costumes ${ }^{209}$.

207 MORAES, Bernardo Ribeiro de. Costume administrativo (direito tributário). Enciclopédia Saraiva do Direito, São Paulo: Saraiva, 1977. Verbete "costume administrativo".

${ }^{208}$ BALEEIRO, Alio mar. Direito tributário brasileiro. 11. ed. atual. por Misabel Abreu Machado Derzi. Rio de Janeiro: Forense, 2007. p. 647.

209 Torres disserta: "Pode-se dizer o mesmo sobre o atendimento a obrigações acessórias, como ocorre no caso de declarações aduaneiras e que, a partir de algum momento, as autoridades passam a entender que o tratamento deveria ser outro nos procedimentos adotados em sucessivos despachos aduaneiros (como ocorreu nas tantas confusões de regimes entre importações 'por conta e ordem' e importações 'por encomenda'). A 
Para Ricardo Lodi Ribeiro, o ordenamento jurídico protege os contribuintes em face da eficácia normativa decorrente da prática continuada da Administração. Quando se fala em direito costumeiro, menciona-se a eficácia normativa adquirida em virtude de uma aplicação geral, contínua e duradoura de determinada norma ${ }^{210}$.

De acordo com Hugo de Brito Machado ${ }^{211}$, as práticas reiteradas das autoridades administrativas representam uma posição sedimentada do Fisco na aplicação da legislação tributária e devem ser acatadas como boa interpretação da lei. Se as atuoridades fiscais interpretam a lei em determinado sentido, e assim a aplicam reiteradamente, essa prática constitui norma complementar da lei. De certo modo, diz o autor, isso representa a aceitação do costume como fonte do Direito.

O Código Tributário Nacional não estabelece nenhum critério para se determinar quando uma prática deve ser considerada de reiterada observância pela autoridade administrativa, devendo-se, todavia, entender como tal uma prática repetida, renovada. Basta que tenha sido adotada duas vezes, pelo menos, para que se considere reiterada ${ }^{212}$.

Por fim, é relevante anotar que, por força do art. 337 do Código de Processo Civil (CPC), a "parte que alegar direito municipal, estadual, estrangeiro ou consuetudinário, provar-lhe-á o teor e a vigência, se assim determinar o juiz".

Segundo Schoueri, a comprovação do costume pode dar-se como se demonstram quaisquer fatos. Não é necessário que a prática seja publicada no Diário Oficial para que dela se conheça, embora, evidentemente, quando a autoridade cuida de tornar público seu entendimento, em uma Solução de Divergência, por exemplo, esta servirá de prova do costume administrativo. Também reiteradas "Decisões" publicadas no Diário Oficial, que refletem respostas das autoridades a consultas formuladas por contribuintes, servem de prova da prática administrativa. Do mesmo modo, se uma repartição seguidamente adota

\footnotetext{
aceitação reiterada pela fiscalização aduaneira da prática adotada pelo contribuinte, apresentada com lídima transparência, com inclusão na Declaração de Importação de todas as informações sobre a operação e seu efetivo destinatário, em diversas ocorrências sem qualquer oposição das autoridades aduaneiras, afirma-se como ato lícito, cuja observância afasta a imposição de penalidades, a cobrança de juros de mora e a atualização do valor monetário da base de cálculo do tributo, nos termos do art. 100, III e parágrafo único, do CTN (TORRES, Heleno Taveira. Direito constitucional tributário e segurança jurídica: metódica da segurança juríd ica do sistema constitucional tributário, p. 244).

210 TREVIJANO, Pedro José Gonzalez. La costumbre en derecho constitucional. Madrid: Publicaciones del Congreso de los Diputados, 1989. p. 351.

${ }^{211}$ MACHADO, Hugo de Brito. Comentários ao código tributário nacional. São Paulo: Atlas, 2004. v. II, p. 93.

${ }^{212}$ Ibidem, p. 93.
} 
certo procedimento, torna-se este costumeiro, gerando a expectativa do contribuinte no sentido de que assim se faz ${ }^{213}$.

Em razão do exposto, tratando-se de costume na esfera do Direito Tributário, deverá a parte que alega incumbir-se de fazer a prova da existência de práticas reiteradas para fazer jus à exclusão aos consectários da mora, nos termos do parágrafo único do art. 100 do CTN.

Colaciona-se a seguir decisão do Superior Tribunal de Justiça (STJ) a respeito da aplicação do mencionado dispositivo:

"1. Restando configurada a prática constante de atos pela administração, há de se aplicar o preceito insculpido no art. 100, III, parágrafo único, do CTN, que exc lui o contribuinte da imposição de penalidade, da cobrança de juros de mora e a atualização do valor monetário da base de cálculo do tributo."

\section{(voto do Ministro JOSÉ DELGADO):}

"No caso presente, não estamos diante de uma norma complementar escrita, é a prática de certo ato de forma reiterada pela autoridade administrativa que integra o próprio conceito de legislação tributária, vinculando seu comportamento e obrigando o contribuinte nos limites de sua eficácia, afastando com isso o discricionarismo e garantindo maior grau de segurança aos contribuintes.

É, portanto, um tipo de fonte secundária que se destina a complementar as leis, tratados, convenções internaciona is e decretos, não podendo alterar o texto da norma que complementa. Mas termina por vincular-se às normas costumeiras, criadas pelas práticas reiteradas das autoridades, revelando significativa importância de ordem prática.

A 'prática reiteradamente observada' em questão vem do fato de as autoridades fiscais, por repetidas vezes, expedirem documentos de importações em nome do contribuinte, registrando-lhe o direito à isenção dos impostos, conforme restou demonstrado documentalmente, mesmo tendo reconhecimento da expiração do prazo de isenção.

O parágrafo único do artigo 100 do CTN é cristalino ao dispor que o efeito das normas complementares nele enumeradas exclui a imposição de penalidades, a cobrança de juros de mora e correção monetária. E nesse rol de normas complementares se inclui a conduta da autoridade administrativa examinada.

Deduz-se, pois, que o contribuinte merece ser protegido contra a mudança de critério adotado pelo Fisco na interpretação da legislação

${ }^{213}$ SCHOUERI, Luís Eduardo. Direito tributário, p. 117. 
tributária. Ele não pode prejudicar, sobretudo punir, o contribuinte pelos fatos anteriores à sua nova orientação. $\mathrm{O}$ princípio da segurança das relações jurídicas se sobrepõe para garantir a estabilidade necessária aos suje itos das obrigações." ${ }^{214}$

A decisão prolatada pelo colendo Tribunal corrobora com o defendido neste estudo acerca das práticas de observância reiterada pela Administração e seus efeitos para o contribuinte.

\subsection{Autoridades Administrativas}

Definidos os contornos da prática administrativa, cabe, agora, debruçar-se sobre a parte final do inciso III, a fim de concluir quem seriam as autoridades administrativas de que trata o artigo em comento.

Como o Código Tributário Nacional não define expressamente quem seriam as autoridades administrativas, é imperativo recorrer a outras fontes.

Segundo defende o Sindicato Nacional dos Auditores-Fiscais da Receita Federal Brasil (Unafisco ${ }^{215}$ ), seriam os auditores fiscais as autoridades administrativas sobre as quais versa o Código Tributário Nacional. Para respaldar a tese que advogam, reportam-se ao art. 142 do CTN:

“Art. 142. Compete privativamente à autoridade administrativa constituir o crédito tributário pelo lançamento, assim entendido o procedimento administrativo tendente a verificar a ocorrência do fato gerador da obrigação correspondente, determinar a matéria tributável, calcular o montante do tributo devido, identificar o sujeito passivo e, sendo caso, propor a aplicação da penalidade cabível."

Assim, com esteio no dispositivo ora reproduzido, defende o órgão representativo dos auditores que autoridade administrativa é a pessoa a quem foi conferido o poder-dever de constituição do crédito tributário mediante o lançamento. Portanto, seria o auditor fiscal,

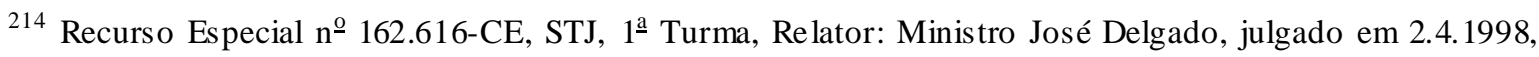
DJ 15.6.1998, p. 53 .

215 Disponível em: <http://www2.unafisco.org.br/noticias/boletins/2007/junho/anexo_2370_analise.pdf>. Acesso em: 10 out. 2013. 
de qualquer um dos entes da Federação, a autoridade administrativa de que trata o Código Tribunal Nacional.

Corrobora com essa afirmação o art. 149 do C TN, segundo o qual: "O lançamento é efetuado e revisto de ofício pela autoridade administrativa nos seguintes casos".

Nesse mesmo sentido também direcionam os arts. 194 e 196 do CTN:

“Art. 194. A legislação tributária, observado o disposto nesta Lei, regulará, em caráter geral, ou especificamente em função da natureza do tributo de que se tratar, a competência e os poderes das autoridades administrativas em matéria de fiscalização da sua aplicação.

$[\ldots]$

Art. 196. A autoridade administrativa que proceder ou presidir a quaisquer diligências de fiscalização lavrará os termos necessários para que se documente o início do procedimento, na forma da legislação aplicável, que fixará prazo máximo para a conclusão daquelas."

Todavia, assim como há dispositivos do Código Tributário Nacional que conduzem a essa conclusão, há outros também, desse mesmo diploma, que contradizem essa assertiva. Contrário ao que advoga a Unafisco têm-se os arts. $138^{216}, 152$, II ${ }^{217}, 153^{218}$,

216 “Art. 138. A responsabilidade é excluída pela denúncia espontânea da infração, acompanhada, se for o caso, do pagamento do tributo devido e dos juros de mora, ou do depósito da importância arbitrada pela autoridade administrativa, quando o montante do tributo dependa de apuração.” (sem grifo no original).

217 “Art. 152. A moratória somente pode ser concedida:

I - em caráter geral:

a) pela pessoa jurídica de direito público competente para instituir o tributo a que se refira;

b) pela União, quanto a tributos de competência dos Estados, do Distrito Federal ou dos Municípios, quando simu ltaneamente concedida quanto aos tributos de competên cia federale às obrigações de direito privado;

II - em caráter individual, por despacho da autoridade administrativa, desde que autorizada por lei nas condições do inciso anterior." (sem grifo no original).

218 “Art. 153. A lei que conceda moratória em caráter geral ou autorize sua concessão em caráter individual especificará, sem prejuízo de outros requisitos:

I - o prazo de duração do favor;

II - as condições da concessão do favor em caráter individual;

III - sendo caso:

a) os tributos a que se aplica;

b) o número de prestações e seus vencimentos, dentro do prazo a que se refere o inciso I, podendo atribuir a fixação de uns e de outros à autoridade administrativa, para cada caso de concessão em caráter individual;

Parágrafo único. Não se considera espontânea a denúncia apresentada após o início de qualquer procedimento administrativo ou medida de fiscalização, relacionados com a infração." (sem grifo no original). 
$163^{219}, 170^{220}, 172^{221}, 179^{222}, 181^{223}$ e $182^{224}$, todos do CTN.

Em todos esses dispositivos há a menção a "autoridades administrativas", entretanto, nenhum deles se relaciona com as atividades desempenhadas pelos AuditoresFiscais. Daí por que a concepção de autoridade administrativa, para fins do disposto no art. 100, inciso III, do CTN é aquela ampla, adotada pelo art. 5ํํㄹ Lei $\mathrm{n}^{\mathrm{o}} 4.898$, de 9 de dezembro de $1965^{225}$, segundo o qual, "Considera-se autoridade, para os efeitos desta lei, quem exerce cargo, emprego ou função pública, de natureza civil, ou militar, ainda que transitoriamente e sem remuneração.".

Dessa forma, adota-se um conceito mais amplo de autoridade administrativa, de tal sorte que deverão ser utilizados os graus da base de confiança expostos no capítulo anterior para avaliar se a prática adotada pela autoridade administrativa era ou não digna de proteger a confiança daquele que confiou.

\footnotetext{
219 “Art. 163. Existindo simultaneamente dois ou ma is débitos vencidos do mes mo sujeito passivo para com a mes ma pessoa jurídica de direito público, relativos ao mes mo ou a diferentes tributos ou provenientes de penalidade pecuniária ou juros de mora, a autoridade administrativa competente para receber o pagamento determinará a respectiva imputação, obedecidas as seguintes regras, na ordem em que enumeradas: [...]" (sem grifo no original).

220 “Art. 170. A lei pode, nas condições e sob as garantias que estipular, ou cuja estipulação em cada caso atribuir à autoridade administrativa, autorizar a compensação de créditos tributários com créditos líquidos e certos, vencidos ou vincendos, do sujeito passivo contra a Fazenda pública." (sem grifo no orig inal).

221 "Art. 172. A lei pode autorizar a autoridade administrativa a conceder, por despacho fundamentado, re missão total ou parcial do crédito tributário, atendendo: [...]" (sem grifo no oriignal).

222 "Art. 179. A isenção, quando não concedida em caráter geral, é efetivada, em cada caso, por despacho da autoridade administrativa, em requerimento com o qual o interessado faça prova do preenchimento das condições e do cumprimento dos requisitos previstos em lei ou contrato para concessão." (sem grifo no original).

223 "Art. 181. A an istia pode ser concedida:

I - em caráter geral;

II - limitadamente:

a) às infrações da legislação relativa a determinado tributo;

b) às infrações punidas com penalidades pecuniárias até determinado montante, conjugadas ou não com penalidades de outra natureza;

c) a determinada região do território da entidade tributante, em função de condições a ela peculiares;

d) sob condição do pagamento de tributo no prazo fixado pela lei que a conceder, ou cuja fixação seja atribuída pela mesma lei à autoridade administrativa." (sem grifo no original).

224 “Art. 182. A anistia, quando não concedida em caráter geral, é efetivada, em cada caso, por despacho da autoridade administrativa, em requerimento com a qual o interessado faça prova do preenchimento das condições e do cumprimento dos requisitos previstos em lei para sua concessão." (sem grifo no original).

${ }^{225}$ Regula o Direito de Representação e o processo de Responsabilidade Administrativa Civil e Penal, nos casos de abuso de autoridade.
} 


\subsection{Práticas Reiteradame nte Observadas pelas Autoridades Administrativas e o Princípio da Confiança Legítima}

Na época de entrada em vigor do Código Tributário Nacional - Lei n⿳ำ 5.172, de 25 de outubro de 1966 -, ainda não estava suficientemente maduro, sobretudo na doutrina e na jurisprudência nacionais, o princípio da proteção da confiança legítima; portanto, seria incorreto afirmar que o art. 100, inciso III, do CTN e as consequências previstas pela aplicação do parágrafo único desse dispositivo teriam nascido do princípio e m estudo.

Baleeiro afirma que, na origem, rezava o art. 109, inciso III, do Anteprojeto Rubens Gomes de Sousa, como complementos da legislação tributária: "As práticas, métodos, processos, usos e costumes de observância reiterada por parte das autoridades administrativas, desde que não sejam contrários à legislação tributária ou à jurisprudência firmada pelo Poder Judiciário". Essa disposição era reiterada no art. 112 daquele Projeto. Repetiu a regra do art. 109, inciso III, o art. 157, inciso III, do Projeto revisto ou Projeto Aranha-Rubens Gomes de Sousa. Fundamentou-as a Comissão em razão da equidade ${ }^{226}$.

De todo modo, além de se aproximar do ponto de vista axiológico da própria equidade, sem dúvida a disposição do art. 100, inciso III, do CTN, com as consequências conferidas pelo parágrafo único do mencionado dispositivo, identifica-se plenamente com o conteúdo do princípio da confiança legítima.

Parcela da doutrina defende a inexistência, na esfera do art. 100 do CTN - ou mesmo do art. 146 -, de qualquer campo para aplicação do princípio da confiança legítima, pois, considerando-se que o princípio em questão nasceria por necessidade ético-jurídica quando o ordenamento fracassasse na proteção do indivíduo, e há dispositivo expresso, não caberia - por falta de necessidade - investigar a confiança depositada pelo contribuinte para fins de protegê-lo.

O argumento, em si, é forte; todavia, o princípio da confiança legítima é considerado a face subjetiva da segurança jurídica.

Essa proteção no campo subjetivo terá lugar nas situações em que o ordenamento objetivamente não o faz, mas também poderá estar presente naquelas em que o legislador, com perspicácia, tenha antecipadamente descrito que, na hipótese desenhada na norma, em

${ }^{226}$ BA LEEIRO, Alio mar. Direito tributário brasileiro, p. 648/649. 
razão do prestígio à confiança individual do contribuinte, haverá proteção positiva ou ne gativa da confiança.

No caso específico do inciso III do art. 100 do CTN, a norma não protegerá o contribuinte pela sua simples aplicação, mas exigirá que demonstre a base da confiança "a prática administrativa reiterada" - e os respectivos investimentos de confiança, que é justamente a comprovação de que se pautou nessas práticas de maneira concreta.

Daí por que, diverso da segurança jurídica em seu aspecto objetivo, a aplicação do art. 100, inciso III, do CTN demandará rigorosamente os mesmos requisitos para fazer jus à proteção da confiança. Trata-se da segurança jurídica "subjetivada".

No mais, é fácil perceber que o artigo em foco se ocupa da questão do tratamento dispensado no retorno da atividade administrativa à legalidade, ou seja, das consequências que o reconhecimento da ilegalidade do ato ou da prática administrativa reputada ilegal gerou durante o tempo de sua vigência.

Nesse ponto, novamente vem à tona a observação de Baleeiro quando discorre sobre a necessidade de se erradicar o vício da restrição do princípio da irretroatividade a uma limitação imposta exclusivamente ao legislador. $\mathrm{O}$ princípio da irretroatividade aplica-se também à totalidade das fontes de formação do Direito, quer às decisões do Poder Judiciário, quer aos atos e decisões do Poder Executivo. Somente assim a segurança jurídica e a proteção da confiança, como valores elementares do Estado Democrático de Direito, podem ser asseguradas. Ao contrário do que se supõe, apenas com o pleno respeito à segurança e à confiança é que a igualdade e a evolução do Direito se tornam possíveis ${ }^{227}$.

Conforme já anotado neste estudo, é preciso lembrar que, na Constituição alemã, inexistem - pelo menos de forma expressa - os princípios da irretroatividade, da anterioridade e da capacidade econômica de contribuir, os quais se põem como normas fundamentais no Direito brasileiro. Não obstante, os germanos não limitam o princípio às leis - no sentido de ato emanado do Poder Legislativo -, mas estendem-no às normas e atos administrativos ou judiciais. O que vale para o legislador precisa valer para a Administração e os Tribunais. Isso significa que a Administração e o Poder Judiciário não podem tratar os casos que estão no passado de modo de que desviem da prática até então utilizada, na qual o contribuinte havia confiado.

${ }^{227}$ BA LEEIRO, Alio mar. Direito tributário brasileiro, p. 650 
O Código Tributário Nacional também adota essa mesma diretriz, porque o parágrafo único do art. 100 exclui a possibilidade de imposição de penalidades, cobrança de juros e mesmo atualização de valor monetário da base de cálculo de tributo, se o contribuinte vinha pautando a sua conduta em atos normativos, decisões ou práticas reiteradas, que depois são alteradas.

Apesar de o estudo da irretroatividade não ter alcançado, no Direito brasileiro, a sistematização desejável, normas do Código Tributário Nacional, que é lei complementar à Constituição no sentido material, já implementam o princípio constitucional, protegendo o contribuinte contra as surpresas e a inconstância da Administração Fazendária ${ }^{228}$.

Essa linha que trata da autovinculação da Administração é corroborada pela doutrina de Hartmut Maurer, segundo o qual

“[...] as prescrições administrativas, pela aplicação contínua, fundamentam uma prática administrativa proporcionada pela qual a própria administração vincula-se, uma vez que ela não pode tratar diferentemente casos configurados igualmente sem fundamento objetivo (chamada autovinculação da administração). A administração infringe, por isso, o princípio da igualdade quando ela, em alguns casos, sem fundamento objetivo justificador, se desvia de sua prática administrativa contínua motivada pelas prescrições administrativas" 229 .

Maria Sylvia Zanella Di Pietro também comunga desse entendimento ao afirmar que,

“[...] se a Administração adotou determinada interpretação como a correta e a aplicou a casos concretos, não pode depois vir anular atos anteriores, sob o pretexto de que foram praticados com base em errônea interpretação [...] por respeito ao princípio da segurança jurídica, não é admissível que o administrado tenha seus direitos flutuando ao sabor de interpretações jurídicas variáveis no tempo" ${ }^{\text {230 }}$.

A legislação também confirma a autovinculação da Administração, bem como a irretroatividade de interpretação, consoante dispos to no art. $2^{\underline{o}}$ da Lei $n^{\underline{o}}$ 9.784/1999:

\footnotetext{
${ }^{228}$ BA LEEIRO, Alio mar. Direito tributário brasileiro, p. 651.

229 MAURER, Hartmut. Direito administrativo geral. Trad. Luís Afonso Heck. Barueri: Manole, 2006. p. 706.

${ }^{230}$ DI PIETRO, Maria Sylvia Zanella. Direito administrativo. São Paulo: Atlas, 2010. p. 95.
} 
“Art. 2ํ․ A Administração Pública obedecerá, dentre outros, aos princípios da legalidade, finalidade, motivação, razoabilidade, proporcionalidade, moralidade, ampla defesa, contraditório, segurança jurídica, interesse público e eficiência.

Parágrafo único. Nos processos administrativos serão observados, entre outros, os critérios de:

$[\ldots]$

XIII - interpretação da norma administrativa da forma que melhor garanta o atendimento do fim público a que se dirige, vedada aplicação retroativa de nova interpretação." (sem grifo no original)

Ávila compartilha dessa mesma ideia e aduz que a prática administrativa é tratada como fonte normativa porque ela pode influenciar a confiança legítima do cidadão ${ }^{231}$. De acordo com o Código Tributário Nacional (art. 100, parágrafo único), um comportamento adotado pelo sujeito passivo com base na prática administrativa impede a imposição de penalidades.

Ricardo Lodi Ribeiro afirma que o art. 100 do CTN representa um prestígio ao princípio da confiança legítima, entretanto, destaca que, em um juízo de ponderação, esse dispositivo dá prevalência ao princípio da legalidade em contraposição ao princípio da confiança legítima ao excluir apenas as penalidades pecuniárias ${ }^{232}$.

Conclui-se, portanto, que o art. 100, inciso III, do CTN, embora inicialmente concebido com expressão de equidade, pode ser considerado regra - na definição que lhe confere Ávila ${ }^{233}$, delineada no Capítulo 1 deste estudo - que expressa o princípio da confiança legítima pelo qual, para aplicação dos efeitos do parágrafo único do art. 100 do $\mathrm{CTN}$, requer-se a análise da base da confiança - assim entendida a prática reiterada em que o contribuinte afirma ter confiado - e dos respectivos investimentos de confiança, que é justamente a comprovação de que houve efetivo comportamento do contribuinte em observância à prática reiterada.

\footnotetext{
${ }^{231}$ Á VILA, Hu mberto Berg mann. Segurança jurídica - entre permanência, mudança e realização no direito tributário, p. 443.

${ }^{232}$ RIBEIRO, Ricardo Lodi. A segurança jurídica do contribuinte: legalidade, não-surpresa e proteção à confiança legítima, p. 250.

${ }^{233}$ Á VILA, Hu mberto Berg mann. Teoria dos princípios, p. 71.
} 


\subsection{Práticas Reiteradamente Observadas pelas Autoridades Administrativas e a Supressio Tributária}

Em estudo sobre o panorama da jurisprudência brasileira a respeito da boa-fé objetiva, Ana de Oliveira Frazão ${ }^{234}$ destaca que a supressio, a qual representa uma modalidade da boa-fé objetiva, consiste na impossibilidade do exercício de direitos ou prerrogativas contratuais em decorrência do transcurso do tempo associado à boa-fé.

Do ponto de vista doutrinário, ainda sob o enfoque do direito privado, Frazão ${ }^{235}$ sustenta que a supressio é vista como forma de perda de direitos ou ao menos como causa de impedimento do exercício de direitos e faculdades contratuais ou de preclusão em razão da boa-fé ${ }^{236}$, estando usualmente associada ao instituto alemão da Verwirkung ${ }^{237}$ e à inatividade injustificada (sitting on one's rights).

A característica fundamental da supressio é o decurso do tempo, visto aqui como fator de estabilização de expectativas de comportamentos e de geração de situações legítimas de confiança que devem ser tuteladas ${ }^{238}$. É a proeminência do tempo que diferencia a supressio de outros subprincípios decorrentes da boa-fé, como o venire contra factum proprium.

A principal diferença é que, no caso da supressio, o tempo constitui o fato próprio a ensejar a extinção de direitos ou a impossibilidade de seu exercício. A existência de lapso temporal significativo é, pois, fundamental para a supressio, enquanto o venire se concentra essencialmente na sucessão de condutas, ainda que entre elas não haja um tempo longo ou considerado relevante ${ }^{239}$.

De qualquer maneira, eventuais distinções entre os princípios não podem ser ultravalorizadas; tanto é assim que muitos consideram a supressio uma modalidade do venire contra factum proprium, ainda que esse fato próprio consista em um

\footnotetext{
${ }^{234}$ FRAZÃO, Ana de Oliveira. Breve panorama da juris prudência brasileira a respeito da boa-fé objetiva no seu des dobramento da supressio. Revista de Direito Privado, v. 44, p. 28-57, out. 2010, p. 28.

235 Ibidem, loc. cit..

${ }^{236}$ Ibidem, loc. cit..

237 MENEZES CORDEIRO, Antonio Manuel da Rocha e. Da boa-fé no direito civil. Lisboa: Almedina. 3. reimpr. 2007. p. 797.

238 FRAZÃO, Ana de Oliveira. Op. cit., loc. cit.; e ZIMMERMAN, Reinhard; WHITTAKER, Simon. Goodfaith in European Contract Law. New York: Cambridge University Press, 2008. p. 516).

${ }^{239}$ MENEZES CORDEIRO, Antonio Manuel da Rocha e. Op. cit., p. 821.
} 
comportamento omissivo destacado pelo transcurso do tempo ${ }^{240}$.

Até por isso, a supressio não pode ser vista como mera consequência do tempo; ela é, sobretudo, uma resposta do ordenamento jurídico para a deslealdade ou a inatividade abusiva do credor, funcionando ao mesmo tempo como forma de proteção daquele que adquiriu a situação de confiança e, por consequência, como verdadeiro mecanismo de implementação da justiça no caso concreto ${ }^{241}$.

Pelos efeitos que a norma jurídica do art. 100, inciso III, e o respectivo parágrafo único, do CTN, espraia sobre a situação do contribuinte que, observando práticas reiteradas das autoridades administrativas, fica resguardado no tocante à aplicação das penalidades moratórias, Torres ${ }^{242}$, em apreciação do princípio da segurança jurídica no sistema tributário nacional, afirma que o dispositivo em foco é aquele que mais se aproxima da supressio, consagrada na esfera do direito privado.

Torres argumenta que essa aproximação da supressio é manifestada por conta de o dispositivo previsto no Código Tributário Nacional representar uma proibição para que a Administração, quando não tenha exercitado seu direito em certo período de tempo, com evidência de estabilidade duradoura, suficiente para aperfeiçoar o suporte fático da reiteração da prática, possa fazê-lo a qualquer tempo ${ }^{243}$.

Assiste, pois, inteira razão ao autor ao afirmar que não poderia a Administração deixar de agir ao momento de aplicação do tributo para, anos mais tarde, alegar sua própria ineficiência ou erros na atuação administrativa, como motivo para o exercício de cobrança de multas $^{244}$ e juros. Impõe, assim, a proteção da boa-fé e a garantia contra esses acréscimos incabíveis.

Nesse aspecto, é importante destacar que a supressio, oriunda do direito privado, tem origem jurisprudencial. Menezes Cordeiro destaca que foram as perturbações

\footnotetext{
${ }^{240}$ FRAZÃO, Ana de Oliveira. Breve panorama da jurisprudência brasileira a respeito da boa-fé objetiva no seu desdobramento da supressio. Revista de Direito Privado, v. 44, p. 28; e .ZIMMERMAN, Reinhard; WHITTAKER, Simon. Goodfaith in European Contract Law. p. 516).

${ }^{241}$ MENEZES CORDEIRO, Antonio Manuel da Rocha e. Da boa-fé no direito civil, p. 815.

${ }^{242}$ TORRES, Heleno Taveira. Direito constitucional tributário e segurança jurídica: metódica da segurança jurídica do sistema constitucional tributário, p. 243.

${ }^{243}$ Ibidem, loc. cit..

${ }^{244}$ A esse propósito, o autor defende haver uma quebra da objetividade do art. 136 do CTN: "Salvo disposição de lei em contrário, a responsabilidade por infrações da legislação tributária independe da intenção do agente ou do responsável e da efetividade, natureza e extensão dos efeitos do ato." (sem grifo no original).
} 
econômicas causadas pela (a) Primeira Grande Guerra e, sobretudo, pela (b) inflação, que induziram à consagração dogmática definitiva da supressio $^{245}$. No primeiro caso, da Grande Guerra, registraram-se alterações imprevisíveis nos preços de certas mercadorias, ou dificuldades acrescidas na realização de determinados fornecimentos. Em consequência dessas alterações, o exercício retardado de alguns direitos levava a situações de desequilíbrio inadmissível entre as partes. No segundo, por meio do chamado direito da valorização monetária, marcaria, pelas aplicações permitidas à supressio, a sua consagração definitiva.

Menezes Cordeiro ${ }^{246}$ lembra que a revalorização monetária conta-se entre os avanços mais significativos proporcionados pela boa-fé à Ciência do Direito. Na sua base está a superação, por razões sociais imperiosas, do princípio nominalista, fixado por lei, mediante pura ação jurisprudencial. Ao admitir a possibilidade de revalorização monetária, por força da inflação, protege-se, no essencial, a posição do credor. A supressio vai funcionar como contrapeso dessa proteção, assegurando, desta feita, o interesse do devedor: a boa-fé requer, pela equivalência das prestações e pelo equilíbrio das situações das partes, que se proceda a reajustamentos destinados a compensar a depreciação monetária; a mesma boa-fé exige que as pretensões de reajustamento, quando caibam, sejam exercidas em um prazo razoável, sem o que atingiriam montantes com que o devedor não poderia contar.

Daí assistir razão a Torres ${ }^{247}$ ao afirmar a estreita relação entre a supressio e o disposto no art. 100, inciso III, do CTN, pelos argumentos expostos alhures, neste estudo.

Em face desses argumentos, o doutrinador supracitado define a norma previs ta no art. 100, inciso III, do CTN como supressio tributária ${ }^{248}$. Em abono a esse entendimento, o Tribunal de Justiça do Estado de São Paulo já se pronunciou afastando a possibilidade de que a Fazenda do Estado de São Paulo prosseguisse com a execução de encargos financeiros não cobrados durante todo o período de parcelamento cujo descumprimento já havia sido caracterizado desde o início do pagamento. Veja-se:

\footnotetext{
${ }^{245}$ MENEZES CORDEIRO, Antonio Manuel da Rocha e. Da boa-fé no direito civil, p. 798-823.

${ }^{246}$ Ibidem, loc. cit..

247 TORRES, Heleno Taveira. Direito constitucional tributário e segurança jurídica: metódica da segurança jurídica do sistema constitucional tributário, p. 243.

${ }^{248}$ Ibidem, loc. cit.
} 
“Apelação Cível. Execução Fiscal. ICMS. Fazenda do Estado.

Extinção do processo com fundamento no art. 794, I, do CPC. Pretensão de reforma da $r$. sentença para prosseguimento a ação com relação a valores que entende devido pelo rompimento do parcelamento do débito fiscal. Inadmissibilidade. Acordo de parcelamento que admitia o pagamento de até três parcelas em atraso de até 30 dias. Executada que quitou todos débitos nos devidos vencimentos, com exceção de quatro parcelas, que foram adimplidas dentro do prazo de 30 dias. Incidência do princípio da boa-fé, razoabilidade e proporcionalidade. Precedentes. Sentença mantida. Recurso não provido" (sem grifo no or iginal).

No caso sob destaque, a fazenda estadual havia ingressado com uma execução fiscal contra o contribuinte, visando à cobrança de débitos em aberto de ICMS. No transcorrer do processo, as partes entabularam um acordo, tendo constado que:

"6. ${ }^{\mathrm{a}}$ Admitir-se-á até três vezes, durante o curso do pagamento, o recolhimento de qualquer das parcelas subsequentes à primeira, com atraso não superior a 30 dias, desde que efetivadas nos termos do art. 637 do Regulamento do ICMS, aprovado pelo Dec. 33.118/1991, com o respectivo acréscimo financeiro calculado em dobro relativamente ao mês em atraso (textual, f.).”

Ocorre que, no caso, o contribuinte executado recolheu quatro parcelas com atraso inferior a trinta dias, sendo as demais honradas nos respectivos vencimentos. Sem prejuízo do atraso de quatro parcelas, e não de três, como previsto no acordo, o parcelamento prosseguiu com o recebimento das demais parcelas sem qualquer oposição da Fazenda estadual $^{249}$.

Entretanto, ao término do parcelamento, a Fazenda estadual afirmou que o parcelamento fora rompido, e pugnou pelo prosseguimento da execução fiscal atinente aos acréscimos financeiros.

A argumentação apresentada pelo Estado não gozou de prestígio na primeira instância, tendo o juiz extinguido a execução, com resolução do mérito, nos termos do art. 794, inciso I, do CPC. A exequente também não obteve êxito em apelação perante o Tribunal de Justiça do Estado de São Paulo, porquanto os desembargadores entenderam ter a Administração sufragado a regularidade da quitação do parcelamento em discussão, pois a Fazenda estadual não se manifestara explicitamente sobre o rompimento do acordo após os recolhimentos em atraso, continuando a emitir os carnês anuais até o pagamento integral das parcelas. ${ }^{249}$ KUGLER, Herbert Morgenstern. Da aplicação do princípio da boa-fé objetiva em questões tributárias -
teoria e jurisprudência. Revista Tributária e de Finanças Públicas, v. 105, jul. 2012, p. 339 . 
A decisão exarada pelo Relator, Desembargador Rui Stoco, conclui nos seguintes termos: "Restou, ainda, evidenciado o integral cumprimento do parcelamento, de modo que, a pretensão da Fazenda Pública resultaria em flagrante violação aos princípios da boa-fé, proporcionalidade e razoabilidade" (sem grifo no original).

De fato, a Fazenda estadual já havia se manifestado quanto à aceitação da quarta parcela em atraso do parcelamento, tanto que continuou a emitir boletos até o pagamento integral da dívida, criando uma expectativa legítima no contribuinte de que seu parcelamento estava regular. Não poderia a mesma Fazenda estadual, posteriormente, contradizer a própria conduta.

É, portanto, escorreito o entendimento de Heleno Taveira Torres de que o art. 100, inciso III, do CTN se aproxima do instituto da supressio.

\subsection{Da Inércia como Configuradora das Práticas Administrativas - Tributos Sujeitos a Lançamento por Homologação}

Uma questão que se coloca de maneira bastante pertinente é a de se a inércia dos agentes fazendários seria apta a configurar a "prática administrativa" para que também nessa hipótese seja aplicado o parágrafo único do art. 100 do CTN. Tal seria o caso, por exemplo, do contribuinte que efetua o lançamento tributário por homologação e, após anos de homologação tácita, no termos do art. $150, \S 4^{\circ}$, do CTN, sofre fiscalização em que autoridade administrativa diverge da interpretação dada pelo contribuinte. E, então, nesta circunstância, o fiscal efetua o lançamento tributário incluindo todas as penalidades legais em razão do lançamento incorreto efetuado pelo contribuinte.

Há quem ${ }^{250}$ sustente não haver, no campo do direito público, a figura do "silêncio eloquente", pelo qual a Administração Pública, ao homologar tacitamente lançamentos anteriores, teria concordado com a prática do contribuinte.

Embora respeite corrente doutrinária divergente, este estudo defende posição segundo a qual o contribuinte que, de boa-fé, efetuou o lançamento tributário por

${ }^{250}$ Para mais detalhes, veja-se BANDEIRA DE MELLO, Celso Antônio. Curso de direito administrativo. São Paulo: Malheiros, 2008. p. 407-409. 
homologação, tendo sido este tacitamente homologado, se vier a repetir essa conduta, poderá, sim, valer-se do disposto no art. 100, inciso III, e respectivo parágrafo único do CTN para afastar a exigência de penalidades e os efeitos da mora.

Reforça essa posição o próprio Parecer no 492/2011 ${ }^{251}$ da Procuradoria-Geral da Fazenda Nacional (PGFN), no qual se buscou dar publicidade ao entendimento que o referido órgão passaria a adotar na hipótese de sentença transitada em julgado em que se reconhece, por exemplo, à empresa-autora o direito de não pagar determinado tributo em razão da inconstitucionalidade da lei que o instituiu, mas que, em sede de controle concentrado, tem alterado o entendimento, com a definição da constitucionalidade da referida norma.

De acordo com o entendimento manifestado no Parecer, a PGFN esclarece que, a partir da publicação da decisão que altera a jurisprudência do STF em sentido contrário à decisão do contribuinte, este não estaria mais protegido contra a exigência do tributo declarado constitucional.

Destaca-se que não é objeto do presente estudo as críticas que poderiam ser feitas à interpretação dada pela PGFN no referido Parecer. É digno de nota, no entanto, que a própria PGFN afirma ser a inércia dos agentes fazendários reveladora dos comportamentos a serem observados pelo contribuinte, conforme reproduzido in verbis:

'[...]

73. Como a cessação da eficácia vinculante da decisão tributária contrária ao posterior entendimento sufragado pela Suprema Corte, conforme demonstrado no item anterior, dá-se de forma automática, vale dizer, independentemente de prévio pronunciamento judicial nesse sentido, pode-se afirmar que o direito de que dispõe o Fisco de voltar a exigir o tributo (tido por inconstitucional pela coisa julgada), ou de que dispõe o contribuinte-autor de deixar o tributo (tido por constitucional pela coisa julgada), surge com o advento do precedente objetivo e definitivo do STF, o que, por sua vez, somente pode-se considerar ocorrido com o seu trânsito em julgado; é que, antes disso, por óbvio, o entendimento firmado no acórdão do STF ainda pode ser alterado, de modo que esse entendimento ainda não pode ser tido como realmente definitivo.

74. É legítimo se afirmar, portanto, que a data do trânsito em julgado do acórdão do STF configura, ao menos como regra, o termo a quo para o exercício dos dire itos acima referidos. Entretanto, essa regra comporta

251 Disponível em: 〈http://dados.pgfn.fazenda.gov.br/dataset/pareceres/resource/4922011>. Acesso em: 13 out. 2013. 
exceção no que tange, especificamente, ao dire ito de que dispõe o Fisco de voltar a exigir, do contribuinte-autor, o tributo antes tido por inexigível pela coisa julgada que lhe favorecia. Assim, em algumas situações específicas adiante expostas, por razões ligadas ao relevante princípio da segurança jurídica, com os seus corolários em matéria tributária, a saber, os princípios da não surpresa e da proteção da confiança, não há como considerar que a data do trânsito em julgado do acórdão proferido pelo STF configura o marco a partir do qual o Fisco possui o direito de efetuar a cobrança do correspondente tributo, relativo a todos os fatos geradores praticados pelo contribuinte-autor desde então.

75. Para que bem se compreenda quais são essas situações específicas, e o porquê da necessidade de excepciona-las, basta pensar na hipótese, que bem as exemplifica, em que de um dado contribuinte tenha deixado de efetuar o pagamento de determinado tributo por reputar que assim estava autorizado em razão de coisa julgada formal, a seu favor, considerando inexistente a correspondente relação jurídica tributária, apesar de esse não pagamento ter se dado quando já existia precedente objetivo e definitivo do STF em sentido contrário ao sufragado na coisa julgada, proferido e transitado em julgado em momento anterior à aprovação e publicação do presente Parecer. E mais: mesmo com o advento desse precedente da Suprema Corte, favorável à Fazenda Nacional - que, segundo aqui se entende, fez cessar a eficácia vinculante da decisão tributária transitada em julgado e, portanto, legitimaria a cobrança do tributo relativo aos fatos geradores ocorridos a partir de então -, o Fisco quedou-se inerte durante anos, não efetuando as correspondentes exigências tributárias.

[...]" (sem grifo no original)

Em outras palavras, a PGFN afirma que a inércia dos agentes fazendários faz presumir que o comportamento dos contribuintes de não efetuar o recolhimento do tributo - mesmo após a publicação da decisão que, segundo seu entendimento, afastaria a sentença que beneficia o contribuinte - é geradora de expectativas legítimas do contribuinte. E prossegue:

\section{$[\ldots]$}

76. Note-se que, na hipótese acima aventada, o contribuinte-autor deixou de pagar o tributo por considerar que assim estava respaldado por coisa julgada, e o Fisco, mesmo diante do precedente do STF, não efetuou as correspondentes exigências tributárias, numa postura omissiva, que, de certo modo, demonstrou sua adesão ao comportamento do contribuinte. Em hipóteses desse jaez - em que (i) a cessação da eficácia da decisão tributária transitada em julgado, face ao advento de precedente objetivo e definitivo do STF, ocorreu em momento anterior à publicação deste Parecer e (ii) não houve lançamento em relação aos fatos geradores ocorridos após o advento do precedente do STF -, não há como legitimamente pretender que, agora, com o entendimento esposado neste 
Parecer, possa o Fisco exigir, do contribuinte-autor, o tributo relativo a todos esses fatos geradores passados (por óbvio, desde que ocorridos há menos de 5 anos).

77. Essa nova exigência, relativa aos fatos anteriores ao presente Parecer, tendo como marco inicial a data, no passado, do advento da decisão do STF, além de causar ao contribuinte-autor surpresa que não parece compatível com a segurança jurídica e a confiança que devem iluminar as relações travadas entre o Fisco e os contribuintes, também representaria ofensa direta ao disposto no art. 146 do CTN, segundo o qual "a modificação introduzida, de ofício ou em consequência de decisão administrativa ou judicial, nos critérios jurídicos adotados pela autoridade administrativa no exercício do lançamento somente pode ser efetivada, em relação a um mesmo sujeito passivo, quanto a fato gerador ocorrido posteriormente à sua introdução". Esse dispositivo legal, cuja essência claramente se inspira nos já invocados princípios da não surpresa e da proteção da confiança, veda que novos critérios jurídicos introduzidos pela Administração Pública Tributária em sua atividade de lançar atinja fatos geradores ocorridos em momento anterior à sua introdução, o que parece impedir que o entendimento contido no presente Parecer - que, inequivocamente, configura um novo critério jurídico relativo a lançamento tributário - aplique-se às situações que lhe são pretéritas.

78. Assim, tendo em conta o princípio da segurança jurídica e os seus consectários princípios da não surpresa e da proteção à confiança, bem como por força do que prevê o art. 146 do CTN (LGLl1966126), entendese, aqui, que naque las específicas hipóteses em que a cessação da eficácia da decisão tributária transitada em julgado, em face do advento de precedente objetivo e definitivo do STF em sentido contrário ao nela sufragado, tenha ocorrido em momento anterior à publicação deste Parecer, e tendo havido inércia dos agentes fazendários, o termo 'a quo' para o exercício, pelo Fisco, do direito de voltar a exigir, do contribuinte-autor, o tributo em questão é a data da publicação deste Parecer, o que significa dizer que apenas os fatos geradores praticados a partir desse instante poderão ser objeto de lançamento .

79. Em outras palavras: este parecer não retroage para alcançar aqueles fatos geradores pretéritos, que, mesmo sendo capazes, à luz do entendimento ora defendido, de fazer nascer obrigações tributárias, não foram, até o presente momento, objeto de lançamento". (sem grifo no original)

A PGFN sufraga, pois, o entendimento de que o comportamento repetido do contribuinte aliado à inércia dos agentes fazendários é motivo para que o contribuinte tenha a justa compreensão de que está agindo em conformidade com a lei. E, dessa maneira, no caso específico do Parecer, afirma que não serão cobrados, no interregno entre a publicação da decisão contrária ao contribuinte e a publicação do Parecer, os tributos que deixaram de ser lançados pelos agentes fazendários e pelos respectivos contribuintes.

Para o presente estudo, as razões expostas no Parecer revelariam mais a própria 
aplicação do art. 100, inciso III, do CTN do que o próprio art. 146. Isso porque não houve ato individual e concreto, tampouco ato normativo algum expedido pela Administração Tributária. Houve, na realidade, comportamento omissivo. Daí por que não caberia a aplicação do art. 146, mas, sim, do art. 100, inciso III, do CTN.

De todo modo, o Parecer evidencia que a postura omissiva repetida dos agentes fazendários, em silêncio que respalda determinado comportamento pelo contribuinte, é digna de proteção, sobretudo, em razão dos princípios decorrentes da segurança jurídica, em especial o da confiança legítima.

Na esteira desse pensamento, Luciano Amaro discorre que a observância das "normas complementares" listadas no dispositivo codificado gera determinados efeitos, decorrentes da proteção da boa-fé do sujeito passivo (art. 100, parágrafo único, do CTN).

Ao tratar das práticas reiteradamente observadas pelas autoridades administrativas (art. 100, III, do CTN), diz o autor tratar-se dos costumes fiscais;

“[...] se, em face de certa norma, e à vista de determinada situação de fato, a autoridade age reiteradamente da mesma maneira (p. ex., aceitando, ainda que tacitamente, uma conduta do contribuinte), esse comportamento da autoridade implica a criação de uma 'norma' que endossa a conduta do contribuinte, e cuja revogação submete-se aos efeitos do parágrafo único do art. 100 do Código" ${ }^{252}$.

Caminha pela mesma trilha Schoueri ${ }^{253}$ ao escrever que se um contribuinte evidencia adotar há anos determinada prática sem que ela jamais tenha sido contestada pela fiscalização, embora esta tenha tomado conhecimento de sua ocorrência - ou deva, razoavelmente, ter tomado em um trabalho rotineiro de fiscalização -, consubstanciado está o costume, apto, portanto, a legitimar a aplicação do parágrafo único do art. 100 do CTN.

A benesse do art. 100, parágrafo único, do CTN, ainda, encontra-se em perfeita sintonia com a justiça fiscal, sobretudo no que se refere - segundo nossa posição - aos tributos sujeitos à homologação.

252 AMARO, Luciano. Direito tributário. São Paulo: Saraiva, 1997. p. 123.

${ }^{253}$ SCHOUERI, Luís Eduardo. Direito tributário, p. 116. 
É que no Brasil, desde meados do século XX, observa-se cada vez mais a transferência para os cidadãos de enorme carga de obrigações que originária e primordialmente caberiam à Adminis tração Pública ${ }^{254}$.

Com o crescente aumento dos chamados tributos sujeitos a lançamento por homologação, dia a dia, foram sendo transferidos serviços burocráticos e até os riscos de interpretação e aplicação das leis tributárias para os contribuintes. A esse fenômeno, Ruy Barbosa Nogueira chamou de burocratização da iniciativa privada ${ }^{255}$, que deixa de despender horas em suas atividades empresariais para dedicá-las a remunerar o Fisco pelas atividades que lhe seriam peculiares.

De todo modo, nesse sistema de lançamento por homologação, uma das obrigações elementares e mesmo indelegáveis do Estado é assegurar aos cidadãos a certeza do direito, assim como lhes garantir a justiça de sua aplicação ${ }^{256}$.

A consulta fiscal e as normas complementares previstas no art. 100 do CTN nada mais são do que instrumentos para que o contribuinte se veja protegido em suas interpretações, já que, pelo lançamento por homologação, todos os riscos de interpretação e aplicação equivocada da imensa legislação fiscal recaem sobre o contribuinte.

Nesta hipótese, a homologação, expressa ou tácita, opera-se positivamente pelo silêncio da Administração ${ }^{257}$ acerca de todos os elementos que, uma vez conhecidos, não foram objeto de contrariedade manifesta por lançamento de ofício, mas, sim, de convalidação dos atos praticados pelo contribuinte. Trata-se de silêncio positivo ${ }^{258}$ e significa a concordância com os atos praticados pelo contribuinte, cuja eficácia consiste em

\footnotetext{
254 NOGUEIRA, Ruy Barbosa. Teoria do lançamento tributário. São Paulo: Revista dos Tribunais, 1965. p. 229.

${ }^{255}$ Ibidem, p. 230.

256 O princípio da proteção da confiança legítima é consequência dos princípios da legalidade, da impessoalidade, da eficiência e da moralidade administrativa, manifestos pela obrigatoriedade da Admin is tração Pública de agir com previsibilidade nas relações com os particulares. O respeito ao princípio da confiança legítima, por conseguinte, integra-se ao princípio da boa Administração Pública, que se define com base em uma atividade desenvolvida segundo critério fundados na transparência, motivação, imparcialidade e probidade, ou seja, orientada à efetividade dos direitos fundamentais, em coerência com o estado de confiança relativo aos seus atos, comissivos e omissivos (TORRES, Heleno Taveira. Direito constitucional tributário e segurança jurídica: metódica da segurança jurídica do sistema constitucional tributário, p. 228).

257 VILCHEZ, Jorge Pando. El silencio administrativo en el procedimiento tributario. In: ABAD YUPANQUI, Samuel B. et al. (Org.). Temas de derecho tributário y de derecho publico: libro homenaje a Armando Zolezzi Möller. Lima: Palestra, 2006. p. 667-668.

258 PÉREZ LUÑO, Antonio-Enrique. La seguridad jurídica. 2. ed. Barcelona: Arie1, 1994. (Cf. A GUADO I CUDOLÀ, Vincenç. Silencio administrativo e inactividad. Madrid: Marcial Pons, 2001. p. 51-134.)
} 
criar uma relação jurídica estável entre este e a Fazenda Pública ${ }^{259}$.

Dessa forma, se o contribuinte lançou por anos tributos sujeitos a lançamento por homologação e o Fisco avalizou tacitamente a interpretação do contribuinte, houve, de maneira indireta, uma indução de comportamento. Logo, deve o contribuinte ser protegido pela aplicação do art. 100, inciso III, do CTN.

Sobre esse tema, o Superior Tribunal de Justiça já se posicionou:

TRIBUTÁRIO. RECURSO ESPECIAL. RECOLHIMENTO REITERADO DO ISS. COSTUME. ART. 100, III E PARÁGRAFO ÚNICO, DO CTN. AUTO DE INFRAÇÃO. ICMS. BOA-FÉ. CONTRIBUINTE. MULTA. EXCLUSÃO. JUROS MORATÓRIOS. CORREÇÃO MONETÁRIA. DIES A QUO. NOTIFICAÇÃO.

I - Presume-se a boa-fé do contribuinte quando este reiteradamente recolhe o ISS sobre sua atividade, baseado na interpretação dada ao Decreto-Lei no ${ }^{406 / 68}$ pelo Município, passando a se caracterizar como costume, complementar à referida legis lação.

II - A falta de pagamento do ICMS, pelo fato de se presumir ser contribuinte do ISS, não impõe a condenação em multa, devendo-se incidir os juros e a correção monetária a partir do momento em que a empresa foi notificada do tributo estadual.

II - Recurso especial improvido. (REsp n⿳⼈ㅡㄹ. 215.655/PR, $1^{\text {a }}$ T., Rel: Min. Francisco Falcão, j. 18.09.2003).

\subsection{Do Parágrafo Único do Artigo 100 do Código Tributário Nacional - Correção Monetária}

De acordo com o parágrafo único do art. 100 do CTN, tem-se que: “A observância das normas referidas neste artigo exclui a imposição de penalidades, a cobrança de juros de mora e a atualização do valor monetário da base de cálculo do tributo." (sem grifo no original).

Aliomar Baleeiro anota que o parágrafo único do art. 100 fixa a norma segundo a qual a observância pelos contribuintes dos atos normativos referidos poderá beneficiá-los jamais criar para eles encargos novos. Na hipótese de a Administração ter errado na interpretação da lei ou mudado de orientação substituindo-a por outra, os contribuintes

259 TORRES, Heleno Taveira. Direito constitucional tributário e segurança jurídica: metódica da segurança jurídica do sistema constitucional tributário, p. 242/243. 
ficam obrigados, por força do princípio da legalidade - obrigação ex lege -, ao pagamento do tributo, mas sem os consectários dos juros, das multas e da correção monetária. Por serem normativos - atos ainda abstratos e genéricos -, bem como atos inferiores aos regulamentos e à lei, o Código garantiu a prevalência hierárquica da lei, para que não fossem certos grupos beneficiados, de forma disfarçada, por isenções e outros favores fiscais. Ao alterar-se a orientação normativa, autoriza-se a cobrança do tributo devido, mas não a de qualquer atualização monetária, juro ou multa ${ }^{260}$.

Em sentido oposto, Ricardo Lodi Ribeiro afirma que o art. 100 do CTN, mediante um juízo de ponderação, dá prevalência ao princípio da legalidade em contraposição ao princípio da confiança legítima ao excluir apenas as penalidades pecuniárias. Segundo sustenta o autor, ao contrário do que prescreve o parágrafo único do art. 100, a boa-fé do contribuinte não afasta a incidência de juros de mora e de correção monetária, uma vez que estas não se relacionam com a prática de qualquer ilicitude, visando apenas à adequação dos valores pagos ao tempo do pagamento. Dispensá-las seria violar a legalidade que, tendo prevalecido no juízo de ponderação, impõe recolhimento integral do tributo, de acordo com o seu valor real no momento do adimplemento ${ }^{261}$.

Na concepção do presente estudo, essa crítica ${ }^{262}$ não prospera. É que o legislador, a quem compete criar regras que antecipem a solução de conflitos, avaliou previamente as normas complementares como dignas de uma confiança parcial, de tal sorte que atenuou de modo parcial os efeitos da retroatividade e, mediante proteção negativa da confiança, estipulou não serem devidos juros de mora, penalidades e atualização monetária do valor da base de cálculo do tributo.

Além disso, consoante exposto no tópico relativo à supressio ${ }^{263}$, é importante observar que a atualização monetária representa um direito do credor, mas que não pode ser exercido se de algum modo, por longo período de tempo, contribuiu para induzir o contribuinte ao não recolhimento do tributo. A supressio tributária atua exatamente para

\footnotetext{
${ }^{260}$ BA LEEIRO, Alio mar. Direito tributário brasileiro, p. 651.

261 RIBEIRO, Ricardo Lodi. A segurança jurídica do contribuinte: legalidade, não-surpresa e proteção à confiança legítima, p. 250.

${ }^{262}$ No IV Simpósio Nacional de Direito Tributário, conceituou-se que, embora não seja sanção, a correção monetária é mera atualização nominal do débito (posição majoritária em plenário), vencida a Comissão III, que entendia tratar-se de sanção de natureza compensatória (art. 100 e parágrafo único do CTN e art. 15 da Lei no 4.862/1965) (posição minoritária em plenário) (MARTINS, Ives Gandra da Silva. Da sanção tributária. 2. ed. rev. e atual. São Pau lo: Saraiva, 1998. p. 223).

263 Cf. item 7.4 - Práticas de Reiteradamente Observadas pelas Autoridades Administrativas e a Supressio Tributária.
} 
impedir que a inércia da Administração Pública culmine em um prejuízo maior ainda ao contribuinte.

Dessa forma, não há nenhuma crítica pertinente à exclusão da correção monetária, já que o próprio princípio da confiança legítima admite mensuração a fim de que se proporcione em maior ou menor grau a sua proteção pelo ordenamento.

Por fim, ao lado do argumento oriundo da mensuração do grau de dignidade da confiança e do próprio instituto da supressio, há um fundamento histórico para não aplicação da correção monetária.

Trata-se do fato que, se hoje a correção monetária dos tributos é algo fora de questionamento, ao tempo de edição do Código Tributário Nacional ainda pendiam posicionamentos divergentes.

No caso específico da correção monetária, Ruy Barbosa Nogueira ${ }^{264}$ faz algumas ponderações sugerindo que deveriam ser observadas no Anteprojeto do Código Tributário Nacional, que viria a ser aprovado dois anos depois.

Naquela época, 1965, escreve o autor que

“[...] um dos temas de maior atualidade e interesse que a ampla reformulação porque está passando a legislação tributária brasileira abordou e ainda não regulou suficientemente, pelo que está exigindo meditação, interpretação e doutrinação, é o da atualização monetária dos débitos fiscais." 265

Segundo esse doutrinador, por meio da Emenda Constitucional n⿳ํㅜ 7, de 22 de maio de 1964, dispôs-se que o princípio da anualidade do tributo - até então vigente - deixou de vigorar, na parte que exigia prévia autorização para a cobrança do tributo em cada exercício, ficando suspensa essa exigência até 31 de dezembro de 1964.

Foi então que o Município de Campinas, por meio da Lei no 3.805 , de 27 de agosto de 1964, estabeleceu:

“Art. 1ํㅡ. Fica instituído um adicional de 100\% (cem por cento) sobre os lançamentos do corrente exercício, dos seguintes tributos municipais:

\footnotetext{
${ }^{264}$ NOGUEIRA, Ruy Barbosa. Teoria do lançamento tributário, passim.

${ }^{265}$ Ibidem, p. 140.
} 
imposto predial, territorial urbano, territorial rural, indústrias e profissões; taxas de água, esgoto, conservação de calçamento e limpeza de vias

públicas, remoção do lixo domiciliar, iluminação pública e conservação de estradas de rodagem."

Observa-se que os tributos a que a Lei Municipal nº 3.085/1964 se referia já estavam lançados e, por meio do referido diploma legal, o Município de Campinas criou um acréscimo de cem por cento sobre esses próprios lançamentos.

Assim, embora hoje esteja suficientemente consolidado na doutrina e na jurisprudência o fato de que o tributo devido pelo contribuinte é aquele cuja lei incidia na época de ocorrência do fato gerador, é importante ter ciência de que por uma interpretação equivocada da Emenda Constitucional no 7/1964, na iminência da aprovação do Código Tributário Nacional, desencadeou-se uma série de violações ao princípio da irretroatividade tributária.

Essa consideração ganha ainda mais força quando se observa que somente pela Lei n⿳ 4.357 , de 16 de julho de 1964, é que se disciplinou a correção monetária dos débitos fiscais, a teor do art. $7^{\circ}$, cuja redação dispôs:

\begin{abstract}
"Os débitos fiscais, decorrentes de não recolhimento na data devida, de tributos, adicionais ou penalidades, que não forem efetivamente liquidados no trimestre civil em que deveriam ter sido pagos, terão seu valor atualizado monetariamente em função das variações no poder aquisitivo da moeda nacional."
\end{abstract}

Com isso, colocava-se em xeque a validade da correção monetária de débitos fiscais anteriores à edição da Lei no ${ }^{4}$ 457/1964. Segundo se afirmava ${ }^{266}$, para grande parte da doutrina, até o dia 16 de julho de 1964, data de criação da referida lei dispondo sobre a atualização da dívida tributária, o débito fiscal era um débito sem correção, simplesmente porque a ordem jurídica lhe conferia essa estrutura e natureza.

À míngua de disciplina legal que autorizasse a atualização monetária do débito, não cabia ao Fisco fazê-lo retroativamente, sob pena de violação ao princípio da irretroatividade tributária e da previsibilidade e da não surpresa.

${ }^{266}$ NOGUEIRA, Ruy Barbosa. Teoria do lançamento tributário, p. 145. 
Desse modo, a não correção monetária dos tributos, na forma do art. 100, parágrafo único, é inteiramente pertinente, porque: (a) à época da aprovação do CTN a correção monetária era tema de debate contemporâneo e, portanto, encontra-se reforçada a decisão tomada pelo legislador de isentar o contribuinte que confiou nas normas complementares que depois se revelariam ilegais; (b) ela representa uma retroação parcial dos efeitos de reconhecimento da invalidade da norma complementar e, dessa forma, decorrente de juízo de mensuração que atribui confiança "parcial" ao ato e também confere apenas uma proteção menor dessa confiança - proteção negativa -; e (c) ela se harmoniza à perfeição ao instituto da supressio, cuja origem é exatamente a impossibilidade de atualização monetária de débito pelo credor após longa e duradoura inércia.

\subsection{Da Aplicação do Artigo 100, Inciso III, e Respectivo Parágrafo Único do Código Tributário Nacional aos Impostos Indiretos}

Definem-se impostos diretos - ou que não repercutem - aqueles cuja carga econômica é suportada pelo contribuinte, isto é, pelo realizador do fato imponível. É o caso do Imposto de Renda (IR), em que o patrimônio de quem auferiu rendimentos líquidos é alcançado por essa tributação.

Já os impostos indiretos ou que repercutem são aqueles cuja carga econômica é suportada não pelo contribuinte, mas por terceira pessoa, que não realizou o fato imponível. Essa terceira pessoa geralmente é o consumidor final da mercadoria ou do produto. É o caso do Imposto sobre Circulação de Mercadorias e Serviços (ICMS). Quem suporta a carga econômica não é o patrimônio, por exemplo, do comerciante que vendeu a mercadoria, mas o patrimônio do consumidor final dessa mesma mercadoria. Este, ao adquirir a mercadoria, verá embutido no preço o quantum de ICMS que foi sendo recolhido por todos os que realizaram as operações mercantis que levaram o bem às suas mãos ${ }^{267}$.

267 CARRAZZA, Roque Antonio. Curso de direito constitucional tributário. São Paulo Malheiros, 2004. p. 477/478. 
No caso dos impostos indiretos, uma questão que surge é, por um lado - pela aplicação do art. 100, inciso III, do CTN, combinado com o parágrafo único do mesmo artigo -, se haveria justiça na não cobrança de penalidade, juros de mora e atualização monetária, mas, por outro, efetuar a cobrança de tributo que, por não poder ser tardiamente transferido ao consumidor final, acabará sendo suportado pelo contribuinte de direito, que deixou de embutir no preço de seu produto ou serviço o valor do tributo que mais tarde se viu obrigado a pagar.

Essa questão é pertinente, tanto que foi alvo de sugestão de acréscimo/alteração no momento da elaboração do Código Tributário Nacional, por Gilberto de Ulhôa Canto, conforme destacado a seguir:

"131. No art. 110, suprimir a ressalva dos juros de mora. Se o contribuinte está exonerado de penalidades outras, deve estar igualmente de multa moratória, que pune a inércia ou o atraso, pelos quais na hipótese êle não é culpável. Nem mesmo o tributo deveria ser exigível, notadamente naqueles casos em que é indireto, e que por isso se transfere ao consumidor, tornando-se irrecuperável ${ }^{, 268}$. (sem grifo no original)

Nesse mesmo sentido são as ponderações de Nogueira ${ }^{269}$ - feitas antes da edição do Código Tributário Nacional -, principalmente quando cita a decisão do Tribunal Federal de Recurso, na Ap. Cív. 1.008 (DJU 13.9.50), onde se declarou que:

"[...] não é possível que as autoridades fiscais orientem a parte de certo modo, para o pagamento do tributo e que posteriormente variando a orientação fiscal venha a parte a responder pelo recolhimento de tributos indiretos, relativos a mercadorias já vendidas a consumidor na base da primeira orientação fiscal, ficando assim sem cobertura".

Nessa mesma trilha, ao ser consultado por empresa que sofreu auto de infração estadual em decorrência de suposto creditamento indevido decorrente de aquisições de

\footnotetext{
${ }^{268}$ CANTO, Gilberto De Ulhôa. Trabalhos da Comissão Especial do Código Tributário Nacional. Rio de Janeiro, 1954. p. 426.

269 NOGUEIRA, Ruy Barbosa. Aspectos do direito tributário na profissão do contabilista e exame de alguns problemas tributários da atualidade. Revista dos Tribunais, ano 50, v. 313, n. 50, p. 20-32, nov. 1961, p. 26-27.
} 
sucata de ferro e metais em geral para ser utilizada como matéria-prima em seus processos de industrialização, cuja orientação fiscal foi previamente precedida de pronunciamento judicial, Ruy Barbosa Nogueira ${ }^{270}$ afirma que, entre outras razões que demonstrariam a nulidade do auto de infração, o Código Tributário Nacional, mesmo para os casos em que o contribuinte tenha sido induzido em erro, por "práticas reiteradamente observadas pelas autoridades administrativas" (art. 100, III), por princípio não só jurídico, mas de ordem moral, exclui qualquer imputação de penalidade, juros de mora ou correção monetária contra o contribuinte, conforme parágrafo único do art. 100 do CTN.

Para corroborar sua assertiva, nessa ordem de ideias, o doutrinador ${ }^{271}$ cita acórdão do STF, pelo qual esse Tribunal decidiu-se precisamente pela exclusão de responsabilidade do contribuinte de direito que não havia antecipado o imposto de consumo - como também é o Imposto sobre Circulação de Mercadorias (ICM) -, em razão de deliberação compulsória e, consequentemente, não tinha podido transferir esse encargo financeiro aos seus clientes. Nesse acórdão, unânime, do STF assim fundamentou, em forma e conteúdo perenes - dirigidos à consciência jurídico-moral da Nação -, o Ministro Orozimbo Nonato:

\begin{abstract}
"O imposto de consumo é devido pelo consumidor, ainda que pago pelo produtor. O produtor é, assim, o coletor, o cobrador da União [...]

Não era, assim, lícito fazer recair o encargo do imposto ao coletor de le, que apenas não o cobrou por não ter sido possível". (Ap. cível 8.208, DJU 5.11.1951)."
\end{abstract}

Essa distinção entre o "coletor" e o "sujeito passivo", entretanto, não prevalece mais, sobretudo à luz da legis lação posterior ao Código Tributário Nacional.

Conforme sustenta Brandão Machado, o terceiro não é devedor de nenhum tributo; devedor é exclusivamente o contribuinte. Para demonstrar a precariedade da tese da figura do "coletor" de impostos, esse autor mostra a incoerência da terminologia, já que o argumento levaria a classificar o contribuinte ora como sujeito passivo, ora como coletor de impostos. No caso da consulta tributária, ademais, não é possível considerar o solvens como mero coletor dos impostos: não fosse ele o verdadeiro sujeito passivo, não teria

\footnotetext{
${ }^{270}$ NOGUEIRA, Ruy Barbosa. Coisa julgada e orientação fiscal. Revista dos Tribunais, n. 594/26, abr. 1985, p. $3 / 4$.

${ }^{271}$ Ibidem, loc. cit..
} 
sequer legitimidade para formular consulta, nos termos do art. 46 do Decreto $\mathrm{n}^{\mathrm{o}}$. $70.235 / 1972^{272}$.

Em outra passagem, Brandão Machado ${ }^{273}$ defende ser incorreto afirmar que a repercussão econômica distingue os impostos diretos dos indiretos. Segundo ele, já há mais de cinquenta anos que se começou seriamente a considerar os impostos pessoais como custos ou despesas diretas, is to é, como elementos integrantes do rendimento tributável. Os impostos tidos por intransferíveis, como o Imposto de Renda, por exemplo, constituem despesas que o contribuinte repassa ao terceiro com quem contrata a venda de bens ou a prestação de serviços.

Explica o autor que o próprio Ministro das Finanças alemão, em memorial preparado em 1924 sobre mudança na lei do imposto de vendas, já observava que, desde havia muito, reconhecia-se o fato de que os impostos diretos também se transladam incorporados no preço.

Em crítica contundente ao art. 166 do CTN, explica Brandão Machado que, ao exigir, para fins de repetição de indébito, que o contribuinte de direito demonstre que não transferiu o encargo financeiro ao terceiro, o Código Tributário Nacional consagraria tese completamente rechaçada nos países europeus, segundo a qual o que justificaria a restituição seria o enriquecimento sem causa e não a própria ilegalidade da exigência de um tributo que não deveria ter sido pago pelo contribuinte de direito.

As impropriedades do art. 166 do CTN no que toca à legitimidade ativa para a repetição do indébito tributário não são, naturalmente, objeto deste estudo; no entanto, é imperativo ponderar que, havendo translação tanto nos impostos diretos quanto nos indiretos, não cabe fazer exceção para, mediante aplicação do art. 100, parágrafo único, do CTN, excluir a cobrança do tributo quando se tratar de imposto indireto e não o fazer quando este for direto.

Mais do que isso: essa questão foi devidamente suscitada por ocasião dos debates na aprovação do que viria a ser o Código Tributário Nacional, e o legislador não optou por fazer essa diferenciação para conferir uma proteção maior àquele que recolheu tributo indireto em relação àquele que recolheu tributo direto.

272 MACHADO, Brandão. Repetição do indébito no direito tributário. In: (Coord.). Direito tributário - estudos em homenagem ao Prof. Ruy Barbosa Nogueira. São Paulo: Saraiva, 1984. p. 59-106. ${ }^{273}$ Ibidem, p. 59-106. 
Da mesma forma que, no imposto indireto, o contribuinte deixou de cobrar do contribuinte de fato o tributo incidente na operação, no imposto direto, o contribuinte deixou de incluir em seu custo aquele tributo que não sabia ser devedor em razão de ter confiado na prática administrativa que se revelou ilegal posteriormente.

\subsection{Campos de Aplicação dos Artigos 146 e 100 do Código Tributário Nacional}

Em matéria tributária há diversas regras que se ocupam da preservação da confiança legítima, da boa-fé e da irrevisibilidade dos atos passados ou afastamento de atos contraditórios. No Brasil, além do art. 100, o art. 146 do CTN é um dos mais objetivos e relevantes, aplicável às modificações dos critérios do lançamento introduzidos por atos administrativos ou decisões. É o seguinte o teor do referido dispositivo:

"Art. 146. A modificação introduzida, de ofício ou em consequência de decisão administrativa ou judicial, nos critérios jurídicos adotados pela autoridade administrativa no exercício do lançamento somente pode ser efetivada, em relação a um mesmo sujeito passivo, quanto a fato gerador ocorrido posteriormente à sua introdução". (sem grifo no original)

Com isso, o Código Tributário consagra regra expressa que confere uniformidade de tratamento aos atos de aplicação de tributos, mediante reconhecimento de "ato jurídico perfeito" dos "fatos geradores" praticados no passado, sob a égide de determinado regime ou tratamento tributário (a), seguido de proibição às autoridades administrativas para que estas possam aplicar, em relação a um mesmo sujeito passivo, qualquer modificação introduzida, de ofício ou em consequência de decisão administrativa ou judicial (b).

Destarte, a modificação introduzida por ato de ofício ou por decisão judicial ou administrativa só terá eficácia para os fatos geradores ulteriores à sua introdução.

$\mathrm{O}$ art. 146 do CTN pode ser aplicado a qualquer processo administrativo ou judicial, inclusive àqueles de controles de inconstitucionalidade, pois o que, em verdade, consagra é um típico caráter de efeito ex nunc para as modificações de critérios jurídicos 
adotados pela autoridade administrativa no exercício do lançamento, as quais somente valeriam para o futuro, sem qualquer concessão de valência para o passado, pela afetação inexorável à vedação à irretroatividade do não benigno e até mesmo à proibição de comportamentos contraditórios, ambos inerentes à segurança do ordenamento.

A aplicação do art. 146 do CTN tem mais uma peculiaridade, qual seja, a de prevalecer sobre qualquer outro tratamento de regime geral, dada a especialidade da Lei Complementar em matéria de obrigação tributária (art. 146, III, "b”, da CF), o que the retira do regime geral em matérias processuais e até mesmo de inconstitucionalidade. Como sustenta José Souto Maior Borges, com acuidade: “O art. 146 denega a atribuição de efeitos retrospectivos ao ato jurisdicional em situações sub iudice antes não gravadas pelo tributo" 274 .

Consagra-se, aqui, o efeito ex nunc para todas as decisões de tribunais em relação ao mesmo contribuinte, independentemente de qualquer efeito prospectivo, na medida em que ao STF, por exemplo, ou qualquer outro tribunal, é defeso contrariar as leis vigentes e constitucionais para dar aplicação a dispositivo de lei declarado inconstitucional ou constitucional e que isso gere efeito sobre critérios pertinentes ao lançamento tributário.

E mesmo que o STF promova a modulação dos efeitos, quando estes tenham como consequência modificações de critérios jurídicos adotados pela autoridade administrativa no exercício do lançamento, ainda assim será defeso à Administração incluir em lançamentos relativos a fatos jurídicos anteriores à decisão do STF qualquer mutação desse tipo $^{275}$.

Corrobora esse pensamento Sacha Calmon Navarro Coêlho, para quem o lançamento tributário já definitivamente constituído é irrevisível pela Administração em caso de erro de direito ou de valoração jurídica dos fatos. É que o art. 146 do CTN impede que a revisão do lançamento por erro na interpretação da lei ou por alteração nos critérios de sua aplicação quando com erronia agiu a própria Administração. O CTN diz que esses critérios jurídicos podem ser alterados pela Administração ao produzir lançamentos, mas

274 BORGES, José Souto Maior. O princípio da segurança na Constituição Federal e na Emenda Constitucional 45/2004. Implicações fiscais. In: PIRES, Adilson Rodrigues; TORRES, Heleno Taveira (Org.). Princípios de direito financeiro e tributário: estudos em homenagem ao professor Ricardo Lobo Torres. Rio de Janeiro: Renovar, 2006. p. 268.

275 TORRES, Heleno Taveira. Direito constitucional tributário e segurança jurídica: metódica da segurança jurídica do sistema constitucional tributário, p. 233-235. 
relativamente a fatos geradores posteriores à alteração. E agrega: no concernente a um mesmo contribuinte ${ }^{276}$.

Para Ricardo Lobo Torres, a norma do art. 146 do CTN tem alcance importante e rico, tendo sido inspirada no art. 176 da Abgabenordnung (Código Tributário Alemão) ${ }^{277}$, que trata da "proteção da confiança na revogação e alteração dos autos de infração" (Vertrauensschutz bei der Aufhebung und Änderung von Steuerbescheiden) cuja tradução feita pelo autor resulta no seguinte dispositivo:

\begin{abstract}
"Na anulação ou alteração de lançamento notificado, não pode ser considerado em detrimento do contribuinte o fato de 1 - a Corte Constitucional Federal declarar a nulidade de uma lei, em que até então se baseava o lançamento; 2 - um Tribunal Superior Federal não aplicar uma norma em que até então se baseava o lançamento, por considera-lo inconstitucional; 3 - ter-se alterado a jurisprudência de um tribunal posterior a qual havia sido aplicada pela autoridade fiscal nos lançamentos anteriores" ${ }^{, 278}$.
\end{abstract}

$\mathrm{O}$ art. 146 do CTN, embora não o diga expressamente, como é o texto da norma germânica, veda a retroação dos novos critérios jurídicos do lançamento: (a) se vêm para agravar a situação do contribuinte; (b) em relação aos fatos geradores, que já foram objeto de lançamento ainda que a alteração pretendida não decorra apenas da mudança de

${ }^{276}$ COÊLHO, Sacha Calmon Navarro. Curso de direito tributário brasileiro. 10. ed. Rio de Janeiro: Forense, 2009. p. 705.

277 "Abgabenordnung:

$\S 176$ Vertrauensschutz bei der Aufhebung und Änderung von Steuerbescheiden

(1) Bei der Aufhebung oder Änderung eines Steuerbescheids darf nicht zuungunsten des teuerpflichtigen berücksichtigt werden, dass

1. das Bundesverfassungsgericht die Nichtigkeit eines Gesetzes feststellt, auf dem die bisherige

Steuerfestsetzung beruht,

2. ein oberster Gerichtshof des Bundes eine Norm, auf der die bisherige Steuerfestsetzung beruht, nicht anwendet, weil er sie für verfassungs widrig hält,

3. sich die Rechtsprechung eines obersten Gerichtshofes des Bundes geändert hat, die bei der bisherigen Steuerfestsetzung von der Finanzbehörde angewandt worden ist.

Ist die bisherige Rechts prechung bereits in einer Steuererklärung oder einer Ste ueranmeldung berücksichtigt worden, ohne dass das für die Finanzbehörde erkennbar war, so gilt Nummer 3 nur, wenn anzunehmen ist, dass die Finanzbehörde bei Kenntnis der Umstände die bisherige Rechtsprechung angewandt hätte.

(2) Bei der Aufhebung oder Änderung eines Steuerbescheids darf nicht zuungunsten des Steuerpflichtigen berücksichtigt werden, dass eine allgemeine Verwaltungsvorschrift der Bundesregierung, einer obersten Bundesoder Landesbehörde von einem obersten Gerichtshof des Bundes als nicht mit dem geltenden Recht in Einklang stehend bezeichnet worden ist."

${ }^{278}$ Cf. TORRES, Ricardo Lobo. A interpretação do direito tributário pela Administração. Separata da ABDF - Resenha - 2. trim. Rio de Janeiro, 1996. p. 13. 
entendimento da própria Administração, mas seja resultante de decisão judicial.

Há também quem identifique no o art. 146 o melhor exemplo da aplicação da teoria da aparência no Direito Tributário. Sabe-se que a teoria da aparência é fundada e justificada na responsabilidade pela confiança gerada. $\mathrm{O}$ contribuinte deve poder confiar nos atos administrativos individuais praticados pela Administração tributária. Se houve erro porque e baseava em lei benéfica que se revelou inconstitucional, ou em jurisprudência que se alterou, a chancela da Fazenda Pública cria a responsabilidade pela aparência, em favor do contribuinte ${ }^{279}$.

Traçado esse panorama do art. 146, passa-se a identificar em que medida ele se relaciona com o próprio art. 100 do $\mathrm{CTN}$.

De acordo com Aliomar Baleeiro, o art. 100 tolera parcialmente a retroatividade do ato administrativo abstrato e genérico, complementar ao regulamento, em homenagem ao princípio da legalidade, por força do qual somente a lei cria, modifica ou extingue obrigação tributária. Mas essa retroatividade é profundamente atenuada para proteção da segurança e da confiança do contribuinte, proibindo o CTN a cobrança de quaisquer juros, multa ou correção monetária, na hipótese de mudança do teor do ato - ou prática reiterada ${ }^{280}$.

Entretanto, se o ato é individual - não normativo -, estando o grau de certeza e liquidez determinado a certo contribuinte, a irretroatividade é plena. Evidente que nenhuma lesão de direito escapa à apreciação do Poder Judiciário. Se o ato administrativo individual é contrário às pretensões do contribuinte, poderá ser revisto na esfera judicial. Não obstante, será definitivo se aplicar a norma mais favorável aos interesses do sujeito passivo - é o que estabelece o art. $146^{281}$ do CTN. O lançamento equivale a uma norma jurídica individual, tanto quanto a sentença, desencadeadora de efeitos inter partes. Embora o ato administrativo não seja dotado da definitividade da coisa julgada, inerente às sentenças proferidas pelo Poder Judiciário, uma vez emanado e cientificado ao sujeito passivo, não poderá ser revisto pela própria Administração em prejuízo do contribuinte.

\footnotetext{
279 DERZI, Misabel Abreu Machado. Modificações da jurisprudência: proteção da confiança, boa-fé objetiva e irretroatividade co mo limitações constitucionais ao poder judicial de tributar, p. 477/488.

${ }^{280}$ BA LEEIRO, Alio mar. Direito tributário brasileiro, p. 652.

281 “Art. 146. A modificação introduzida, de ofício ou em consequiência de decisão administrativa ou judicial, nos critérios jurídicos adotados pela autoridade administrativa no exercício do lançamento somente pode ser efetivada, em relação a um mes mo sujeito passivo, quanto a fato gerador ocorrido posteriormente à sua introdução."
} 
A intervenção do Poder Judiciário, que detém o monopólio da jurisdição, far-se-á, então, sempre em favor e benefício do contribuinte, proibindo-se à Fazenda rever os próprios critérios jurídicos, que presidiram a elaboração do ato.

Assim, no caso do art. 146, por se tratar de norma individual e concreta, eventual mudança do critério só tem efeitos para o futuro. Já o parágra fo único do art. 100 tem conteúdo diverso. Refere-se a atos, decisões ou práticas que tenham efeito normativo, isto é, aplicação genérica e abstrata - similar à da norma legal, embora secundária. Para esses atos, admite-se retroação limitada - restrita à cobrança do tributo, em seu valor original, sem incidência de atualização monetária, juros ou multa -, em respeito ao império da própria leia e de sua posição hierárquica dominante ${ }^{282}$.

Para Torres, tem-se, no caso do art. 100, inciso III e parágrafo único, do CTN exemplo expressivo de preservação da boa-fé em matéria tributária, exercida pelo instituto da supressio. Não se confunde, porém, com nenhuma das hipóteses de modificação de critérios elencadas no art. 146 do CTN, porque, neste caso, nenhum critério do lançamento vê-se alterado. A supressio tributária protege unicamente contra a cobrança de acréscimos moratórios e punitivos, a exemplo do que ocorre no direito privado ${ }^{283}$.

Segundo Misabel Derzi, na hipótese de ato ilegal que tenha favorecido o contribuinte, evidentemente, a legalidade deve ser restabelecida, mas as modificações inovadoras poderão ter os seus efeitos atenuados por força, exatamente, de outros princípios de origem constitucional, o princípio da irretroatividade - nos casos de singela modificação de entendimento -, da proteção da confiança e da boa-fé objetiva. Em que medida deverão ser atenuadas as consequências derivadas dessas retificações? A autora sustenta que a solução dessas questões deve pautar-se por três pressupostos distintos, a nortear as diferentes atuações desses princípios:

"[...]

se a lei, de forma expressa, já previu as consequências, disciplinando-as, a solução não poderá ser fugir dessa regulação legal, a não ser que ele seja afrontosa à Constituição vigente. Não sendo o caso de inconstitucionalidade da lei, as omissões poderão ser cobertas pela busca dos princípios da proteção da confiança e da boa-fé; e deve-se identificar

\footnotetext{
${ }^{282}$ BA LEEIRO, Alio mar. Direito tributário brasileiro, p. 652.

283 TORRES, Heleno Taveira. Direito constitucional tributário e segurança jurídica: metódica da segurança jurídica do sistema constitucional tributário, p. 245.
} 
o dire ito ao planejamento usual, decorrente das leis tributárias, de cunho fiscal, em que se protege, sim, a liberdade de praticar atos, firmar contratos e negócios, com vistas à economia de imposto ou à ordenação da vida econômica privada, inferida pelo cidadão, a partir das normas, baixadas pela própria Administração tributária, de modo genérico. Em relação a tais atos, pode-se encontrar:

(b.1) normas modificativas de atos normativos gerais, genéricos, práticas administrativas e possíve is indutores do comportamento dos cidadãoscontribuintes, cujas consequências já estão disciplinadas no art. 100, parágrafo único do Código Tributário Nacional, de forma expressa ou implícita; e

(b.2) atos retificadores e modificativos de outros atos administrativos, individuais, de lançamento e cobrança dos tributos, cujas consequências estão disciplinadas no art. 146 do Código Tributário Nacional" ${ }^{284}$.

Em relação às hipóteses, anotadas na letra (b), levantam-se as soluções expressas das normas, dispostas no art. 100, parágrafo único, e art. 146, ambos do CTN.

Para as situações descritas em (b.1), o primeiro, o art. 100, é aplicável, mas ele não se pronuncia, explicitamente, sobre os efeitos das modificações introduzidas nos decretos regulamentares executivos e somente disciplina as consequências derivadas das normas administrativas complementares, ou seja, daquelas de hierarquia inferior aos decretos, como os atos normativos, pareceres normativos, decisões de órgãos singulares ou coletivos a que a lei atribua efeito normativo, costumes e prática reiterada da Administração e os convênios, que entre si celebrem a União, os Estados, o Distrito Federal e os Municípios. Em relação a todos eles, o CTN não protege a confiança, positivamente - e, sim, negativamente -, como poderia ser o caso de se conferir efeitos ex nunc às referidas modificações ${ }^{285}$.

Em rigor, o art. 100 admite a retroação, mas atenua-lhe os efeitos, ao estabelecer, no parágrafo único, que "A observância das normas estabelecidas neste artigo exclui a imposição de penalidades, a cobrança de juros de mora e a atualização do valor monetário da base de cálculo do tributo". O mínimo ético é preservado.

O parágrafo único do art. 100 fixa a norma segundo a qual a observância pelos contribuintes dos atos normativos ou prática administrativa nele referidos poderá beneficiálos - jamais criar para eles encargos novos. Na hipótese de a Administração ter errado na

${ }^{284}$ DERZI, Misabel Abreu Machado. Modificações da jurisprudência: proteção da confiança, boa-fé objetiva e irretroatividade co mo limitações constitucionais ao poder judicial de tributar, p. 477-488.

${ }^{285}$ Ibidem, loc. cit.. 
interpretação da lei ou mudado de orientação, substituindo-a por outra, no espaço consentido pela lei e pelo decreto regulamentar, os contribuintes serão obrigados, por força do princípio da legalidade e da hierarquia dos atos administrativos, ao pagamento do tributo, mas sem os consectários dos juros, das multas e da correção monetária.

Portanto, o art. 100 tolera, parcialmente, a retroatividade da mudança introduzida pelo ato administrativo normativo, complementar ao regulamento, mas de forma profundamente atenuada para proteção da segurança e da confiança legítima do contribuinte, proibindo o CTN a cobrança de quais juros, multa ou correção monetária.

Já para as situações descritas na letra (b.2), as soluções estão previstas no art. 146. Isso porque, se o ato é individual - não normativo -, estando o grau de certeza e liquidez determinado a certo contribuinte, a irretroatividade é plenamente garantida. Será ele definitivo se aplicar a norma de forma mais favorável aos interesses do sujeito passivo.

Com efeito, doutrina e jurisprudência têm estabelecido distinção entre erro de fato e erro de direito. $\mathrm{O}$ erro de fato é passível de modificação espontânea pela Administração, mas não o erro de direito. Ou seja, o lançamento torna-se imutável para a autoridade, exceto por erro de fato. Juristas como Rubens Gomes de Sousa ${ }^{286}$ e Gilberto de Ulhôa Canto $^{287}$ defenderam essa tese, que acabou vitoriosa, na lei e nos tribunais superiores ${ }^{288}$.

De acordo com essa corrente dominante, erro de fato resulta da inexatidão ou incorreção dos dados fáticos, situações, atos ou negócios que dão origem à obrigação. Erro de direito diz respeito à incorreção dos critérios e conceitos jurídicos que fundamentaram a prática do ato administrativo ${ }^{289}$.

Em conclusão, pela análise do art. 100 e do art. 146 do CTN, pode-se afirmar o que se segue: (a) ambos são instrumentos de proteção da confiança legítima do contribuinte; (b) enquanto o art. 100 admite retroação apenas parcial do novo entendimento pela Administração Pública, o art. 146 do CTN protege o contribuinte por meio da irretroatividade plena na mudança de critério jurídico; e (c) para aplicação do art. 146 do CTN exige-se um ato individual e concreto ao passo que o art. 100 versa sobre ato genérico e abstrato, incluindo, portanto, as práticas reiteradamente observadas pelas autoridades administrativas.

\footnotetext{
286 SOUSA, Rubens Go mes de. Estudos de direito tributário. São Paulo: Saraiva, 1950. p. 229.

${ }^{287}$ CANTO, Gilberto de Ulhôa. Temas de direito tributário. Rio de Janeiro: Alba, 1964. v. I, p. 176 e ss..

288 Cf. Súmula no 227 do antigo Tribunal Federal de Recursos (TFR): "A mudança de critério jurídico adotado pelo fisco não autoriza a revisão de lançamento.".

${ }^{289}$ SOUSA, Rubens Gomes de. Op. cit., p. 229; e CANTO, Gilberto de Ulhôa. Op. cit., 1964. v. I, p. 176.
} 


\section{CONCLUSÃO}

A presente dissertação de mestrado teve como propósito analisar a aplicação do princípio da confiança legítima no Direito Tributário brasileiro, com foco no art. 100, inciso III, do Código Tributário Nacional (CTN), que trata das práticas reiteradamente observadas pelas autoridades administrativas. O estudo realizado permitiu concluir-se que:

1. o princípio da confiança legítima representa a esfera subjetiva da segurança jurídica e pode ser justificado com base em inúmeros princípios, como os da liberdade, da propriedade, do Estado de Direito, da irretroatividade e da segurança jurídica;

2. o princípio da proteção da confiança é um princípio ético-jurídico que permanece como pano de fundo, sempre aflorando naqueles casos em que a segurança-garantia, disponibilizada e regulada pela ordem jurídica fracassa, mas também se manifesta quando há tutela, pelo ordenamento, do aspecto subjetivo da segurança jurídica;

3. o princípio da confiança legítima se aproxima da boa-fé, na medida em que ambos são princípios éticos, e, portanto, formas de compensação corretiva da justiça, guardando fluidez e indeterminação em sua materialidade;

4. embora o princípio da confiança legítima se aproxime da boa-fé, há situações, sobretudo ligadas à relação com o "tempo", em que somente o primeiro estará presente, quais sejam: (a) a irretroatividade das leis; (b) a obrigatoriedade do cumprimento de promessas e de prestação de informações; (c) a proteção contra a quebra ou modificação de regras administrativas; (d) a proteção contra a modificação retroativa da jurisprudência; e (e) a garantia da execução de planos governamentais;

5. o princípio da confiança, diversamente da boa-fé, somente pode ser utilizado de modo unilateral em favor do contribuinte/cidadão e contra o Estado; e, em contrapartida, o princípio da boa-fé objetiva é fonte de deveres e de obrigações, o que não ocorre com a proteção da confiança;

6. há, por um lado, quem coloque a proteção da confiança como princípio mãe e, portanto, em posição inferior à boa-fé objetiva e, por outro, há inúmeros países em que o 
princípio da confiança foi construído como sendo oriundo da boa-fé objetiva;

7. a segurança jurídica revela-se, no plano objetivo, pela estabilidade sistêmica e, sobretudo, pelo princípio da certeza do direito;

8. a certeza do direito ou segurança jurídica por orientação gera uma expectativa legítima de confiabilidade no sistema jurídico, pela ação dos órgãos de produção de normas, mas também sobre direitos assegurados, estando envolvidas as regras de hierarquia de normas, as fontes de produção e a solução de antinomias, guardando, assim, coerência para a inexistência de contradições internas;

9. a certeza do direito é fundamental no Direito Tributário porque dela decorre a previsibilidade do direito, que permite ao contribuinte planejar suas atividades, prevenindo-o de riscos, sanções e conflitos;

10. a certeza do direito é uma garantia contra o arbítrio dos intérpretes, mas também um meio de garantir a "orientação" das condutas, para que todos saibam previamente quais são os seus direitos e deveres e os cumpram na maior medida possível;

11. à certeza do direito alia-se a cognoscibilidade do direito, que exige determinação de conceitos, objetividade e clareza das leis tributárias, já que as dificuldades na definição das condutas podem ind uzir contribuintes a erros ou ao descumprimento da legislação;

12. como condição para maior cognoscibilidade do direito, o Sistema Tributário Nacional deve procurar reduzir, permanentemente, a indeterminação de suas regras, mediante ações e procedimentos que confiram certeza aos conteúdos das competências, dos direitos e garantias inerentes às medidas de justiça do sistema tributário, para que se obtenha estabilidade na aplicação das leis tributárias;

13. a cogno scibilidade do direito estipula que o sistema jurídico de um Estado Democrático deve garantir o amplo acesso ao conhecimento do direito porque suas regras são heterônomas, provenientes das mais diversas fontes, e o seu desconhecimento é inescusável, já que a ninguém é dado ignorar a lei;

14. a inteligibilidade dos diplomas normativos encontra-se estampada na Lei $\mathrm{n}^{\underline{0}}$ 95/1998, que versa sobre essa exigência de clareza e precisão na redação dos textos das normas;

15. a certeza e, sobretudo, a cognoscibilidade do direito, têm cada vez mais importância em face da inflação legislativa imposta aos contribuintes, que cada vez mais dependem de um corpo técnico para desdobrar uma infinidade de leis, atos normativos, portarias e 
resoluções diariamente colocados no sistema jurídico sem nenhuma sistematização ou clareza;

16. a certeza do direito, como expressão de segurança jurídica, decorre da expectativa de previsibilidade sobre as condutas do Estado na regular positivação do direito. Trata-se, assim, do aspecto objetivo da segurança jurídica, enquanto ao princípio da confiança legítima cabe a proteção da segurança jurídica sob o enfoque subjetivo;

17. a lei direciona-se para o regramento do futuro, mediante a antecipação da solução a ser dada aos conflitos, e a irretroatividade da lei serve de instrumento para a proteção do passado;

18. a Constituição Federal consagra apenas a irretroatividade da lei, pela dedução lógica de que não haveria necessidade de consagrá-la também ao Poder Executivo, cuja atuação deve ser fiel à lei, e nem ao Poder Judiciário, que tem o papel de aplicar a lei previamente colocada no ordenamento pelo Poder Legislativo;

19. o princípio da confiança legítima encontra espaço para aplicação na situação em que o ato ilegal, após período duradouro, cria benefícios ou situações jurídicas para o administrado que o reconhecimento da ilegalidade por meio de revisão administrativa ou declaração judicial culminará em atingir retroativamente situações jurídicas consolidadas - impondo sanções e prejuízos - em decorrência de ato com aparência de legalidade, que despertou a respectiva confiança, e que depois se revelou ilegal;

20. o princípio da confiança legítima entra em cena exatamente para proteger o contribuinte que dispôs de sua liberdade e de seu patrimônio confiando na validade do ato que posteriormente se revelou ilegal de sorte a impedir - total ou parcialmente que haja a retroação dos efeitos do reconhecimento dessa ilegalidade;

21. três fundamentos sustentavam concepção antiga do Supremo Tribunal Federal (STF) considerando o ato ilegal inapto a produzir efeitos. O primeiro defendia ideia oriunda do Direito Privado, segundo a qual o ato nulo não sana, não convalesce. O segundo residia na coerência do sistema ligado à hierarquia das normas, de sorte que se um ato ilegal mantivesse seus efeitos mesmo após o reconhecimento da ilegalidade, estar-se-ia sobrepondo-o à Constituição Federal e, por consequência, entrar-se-ia em rota de colisão com o princípio da supremacia da Lei Maior. Por fim, o terceiro fundamento dizia respeito à natureza declaratória das decisões do STF, o que faz que os efeitos automáticos do reconhecimento da inconstitucionalidade/ilegalidade sejam ex tunc; ou 
seja, o STF reconhece a nulidade $a b$ initio da norma e não somente a partir da decisão que ele profere;

22. Somente, portanto, com a entrada em vigor das Leis $n^{-0}$ 9.784, de 29 de janeiro de 1999 , n 9.868, de 10 de novembro de 1999; e n⿳⺈ 9.882, de 3 de dezembro de 1999, que dispõem, respectivamente, sobre o processo administrativo da União, a Ação Declaratória de Constitucionalidade, a Ação Direta de Inconstitucionalidade e a arguição de descumprimento de preceito fundamental, é que se referiram à segurança jurídica, quer como princípio geral da Administração Pública, de matriz constitucional, a justificar a permanência no mundo jurídico de atos administrativos inválidos, quer como valor constitucional a ser ponderado, em determinadas circunstâncias, em cotejo com os princípios da supremacia da Constituição e da nulidade ex tunc da lei inconstitucional;

23. Após a entrada dessas leis no ordenamento jurídico brasileiro, o STF alçou o princípio da segurança jurídica em sua dimensão subjetiva ao mesmo nível do princípio da legalidade, de sorte a permitir a ponderação entre eles no caso concreto;

24. os requisitos para a configuração do princípio da confiança legítima são: (a) base da confiança, isto é, se o ato era passível de despertar confiança no administrado; (b) a boa-fé (ausência de fraude, conluio etc.), lembrando que ninguém confia mais do que aquele que não sabe que confia; (c) os investimentos de confiança, ou seja, é preciso que tenha havido atos concretos cujos efeitos serão afetados se não houver a proteção; e (d) a imputabilidade revelada pela relação direta entre o responsável pela confiança gerada e o prejudicado.

25. a avaliação, gradual (e não classificatória) da base da confiança (item 24.a, acima), auxilia a definir se a base é digna de confiança ou não. Em síntese, os critérios serão: (a) grau de vinculação da base; (b) grau de aparência de legitimidade da base; (c) grau de modificabilidade da base; (d) grau de eficácia no tempo da base; (e) grau de realização das finalidades da base; (f) grau de indução da base; (g) grau de individualização da base; e (h) grau de onerosidade da base;

26. no campo dos mecanismos de aplicação do princípio da confiança legítima, viu-se que a proteção pode ser positiva, com a manutenção dos efeitos do ato ilegal ou, negativa, neste caso cabendo o ressarcimento dos danos sofridos. Lembrou-se, ainda, a necessidade de ponderação dos interesses envolvidos para que a aplicação do princípio 
da confiança legítima não resulte em uma "socialização" inadvertida dos prejuízos oriundos da responsabilidade de um único indivíduo ou grupo de indivíduos;

27. a atuação do Poder Executivo pode dar-se de três formas: (a) atuação administrativa abstrata e geral, por meio dos atos normativos - nesta hipótese, como há o preenchimento de conceitos legais por meio do ato, a irretroatividade é plena em função da própria atuação "dentro" da lei; (b) atuação individual e concreta, que engloba a resposta à consulta ou mudança administrativa de critério de lançamento, devendo haver igualmente proteção plena, na forma do art. 146 do CTN; e (c) a prática administrativa, que também se trata de uma atuação abstrata e geral, cuja proteção dáse pela aplicação do art. 100, inciso III, combinado com o parágrafo único desse mesmo artigo;

28. as normas complementares são fontes secundárias do Direito Tributário e o inciso III do art. 100 do CTN é a consagração do "costume administrativo" também como fonte secundária do Direito Tributário;

29. em se tratando de costume, deverá a parte que o alegar, fazer a respectiva prova, nos termos do art. 337 do CPC;

30. as autoridades administrativas de que trata o inciso III do art. 100 do CTN não se limitam aos auditores fiscais, mas a todo aquele que exerce cargo, emprego ou função pública, de natureza civil, ou militar, ainda que transitoriamente e sem remuneração, nos termos do art. 5ํㅡㄹ da Lei n⿳ 4.898, de 9 de dezembro de 1965, que regula o direito de representação e o processo de responsabilidade administrativa civil e penal, nos casos de abuso de autoridade;

31. o art. 100, inciso III, do CTN, embora inicialmente concebido com expressão de equidade, pode ser considerado uma regra - na definição que lhe confere Ávila, delineada no Capítulo 1 deste estudo - que expressa o princípio da confiança legítima pelo qual, para aplicação dos efeitos do parágrafo único do art. 100 do CTN, terá de se analisar a base da confiança, assim entendida a prática reiterada em que o contribuinte afirma ter confiado, e os respectivos investimentos de confiança, que é justamente a comprovação de que houve efetivo comportamento do contribuinte em observância à prática reiterada;

32. o inciso III, combinado com o parágrafo único, ambos do art. 100 do CTN, representa a aplicação do princípio da confiança legítima - pautado na mensuração da base da 
confiança -, na medida em que atenua a retroatividade (retroação parcial) e concede ao administrado uma proteção negativa (retirada do ato ilegal e mitigação dos efeitos das sanções) por entender que a base é digna apenas de uma parcela de confiança (e não total);

33. o art. 100, inciso III, do CTN se aproxima muito da supressio consagrada no Direito Privado, porquanto impõe igualmente perda ao credor que se manteve inerte no tocante ao seu direito por longo período de tempo para proteção do devedor;

34. se o contribuinte lançou por anos tributos sujeitos a lançamento por homologação e o Fisco avalizou modo tácito a interpretação do contribuinte, indiretamente houve uma indução de comportamento e, portanto, mesmo não havendo um ato "positivo" de homologação da Administração Pública, estará configurada a hipótese do art. 100, inciso III, do CTN, com as proteções irradiadas pelo respectivo parágafo único;

35. a não correção monetária dos tributos, na forma do art. 100, parágrafo único, é inteiramente pertinente, porque: (a) à época de aprovação do Código Tributário Nacional a correção monetária era tema de debate bastante atual e, portanto, encontrase reforçada a decisão tomada pelo legislador de isentar o contribuinte que confiou nas normas complementares que depois se revelariam ilegais; (b) ela representa uma retroação parcial dos efeitos de reconhecimento da invalidade da norma complementar e, desse modo, decorrente de juízo de mensuração que atribui confiança "parcial" ao ato e também confere apenas uma proteção menor dessa confiança (proteção negativa); e (c) ela se harmoniza à perfeição ao instituto da supressio, cuja origem é exatamente a impossibilidade de atualização monetária de débito pelo credor após longa e duradoura inércia;

36. é incorreta a tese segundo a qual, na hipótese do art. 100, inciso III, do CTN e respectivo parágrafo único, no caso dos impostos indiretos não se deveria sequer cobrar o tributo. O motivo dessa incorreção reside no fato de que, assim como, no imposto indireto, o contribuinte deixou de cobrar do contribuinte o tributo incidente na operação, no imposto direto, o contribuinte deixou de incluir em seu custo aquele tributo que não sabia ser devedor em razão de ter confiado na prática administrativa que se revelou ilegal posteriormente - daí não se justificar qualquer diferenciação dos efeitos do parágrafo único do art. 100 do C TN no caso de se tratar de imposto direto ou indire to; e 
37. pela análise do art. 100 e do art. 146 do CTN, pode-se afirmar: (a) ambos são instrumentos de proteção da confiança legítima do contribuinte; (b) enquanto o art. 100 admite retroação apenas parcial do novo entendimento pela Administração Pública, o art. 146 do CTN protege o contribuinte por meio da irretroatividade plena na mudança de critério jurídico; e (c) para aplicação do art. 146 do CTN exige-se um ato individual e concreto enquanto o art. 100 versa sobre ato genérico e abstrato, incluindo, portanto, as práticas reiteradamente observadas pelas autoridades adminis trativas. 


\section{REFERÊNCIAS}

ACHTERBERG, Norbert. Allgemeines Verwaltungsrecht. Heidelberg: C. F. Müller, 1982.

AFONSO, Sylvio César. Fontes de direito tributário: lei federal, lei complementar e o papel do CTN. Revista Tributária e de Finanças Públicas, v. 69, jul. 2006.

AGUADO I CUDOLÀ, Vincenç. Silencio administrativo e inactividad. Madrid: Marcial Pons, 2001. p. 51-134.

ALEXY, Robert. Rechtsregeln und Rechtsprinzipien. Archives Rechts und Sozialphilosophie. Separata 25. Frankfurt am Main, 1995a.

Rechtssystem und praktische Vernunft. Recht, Vernunft, Diskurs. Frankfurt am Main, Suhrkamp, 1995b.

Theorie der Grundrechte. 2. ed. [S.1.], [S.d.].

. Zum Begriff des Rechtsprinzips. Argumentation und Hermeneutik in der

Jurisprudenz, Rechtstheorie. Separata 1. Berlin, Dunckler und Humblot, 1979.

AMARO, Luciano. Direito tributário. São Paulo: Saraiva, 1997.

ANDRADE, Fábio Martins de. Algumas questões pendentes em torno do art. 27 da Lei 9.868/1999. Revista Tributária e de Finanças Públicas, v. 93, jul. 2010.

ATALIBA, Geraldo. Hipótese de incidência tributária. São Paulo: Malheiros, 2008.

ÁVILA, Humberto Bergmann. A distinção entre princípios e regras e a redefinição do dever de proporcionalidade. Revista de Direito Administrativo, Rio de Janeiro, n. 215, p. 151-152, jan./mar. 1999.

Benefícios fiscais inválidos e a legítima expectativa do contribuinte. Revista Eletrônica de Direito Administrativo Econômico, Salvador, Instituto de Direito Público da Bahia, n. 4, nov./dez. 2005, jan. 2006.

. Segurança jurídica - entre permanência, mudança e realização no direito tributário. São Paulo: Malheiros, 2011.

. Sistema constitucional tributário. 4. ed. São Paulo: Saraiva, 2010.

Teoria dos princípios. 11. ed. São Paulo: Malheiros, 2010.

BADURA, Peter et al. Allgemeines Verwaltunsrecht. Berlin: Walter de Gruyter, 1995. 
BALEEIRO, Aliomar. Direito tributário brasileiro. 11. ed. atual. por Misabel Abreu Machado Derzi. Rio de Janeiro: Forense, 2007.

. Direito tributário brasileiro. Rio de Janeiro: Forense, 1970.

Limitações constitucionais ao poder de tributar. Rio de Janeiro: Forense, 1977.

BANDEIRA DE MELLO, Celso Antônio. Curso de direito administrativo. São Paulo: Malheiros, 2009.

Curso de direito administrativo. São Paulo: Malheiros, 2008.

A estabilidade dos atos administrativos. RTDP, São Paulo, n. 48, p. 77-83,

2005 .

Leis originariamente inconstitucionais compatíveis com emenda constitucional superveniente. RDP, São Paulo, n. 81, p. 109-116, 2001.

BANDEIRA DE MELLO, Oswaldo Aranha. Princípios gerais de direito administrativo. 3. ed. São Paulo: Malheiros, 2007. v. I.

BAPTISTA, Patrícia. A tutela da confiança legítima como limite ao exercício do poder normativo da administração pública - a proteção às expectativas legítimas dos cidadãos como limite à retroatividade normativa. Revista de Direito do Estado (RDE), Rio de Janeiro, n. 3, p. 155-181, 2006.

BARROSO, Luís Roberto. Vinte anos da Constituição de 1988: a reconstrução democrática do Brasil. Revista Justitia, São Paulo, v. 198, p. 255-267, jan./jun. 2008.

BASTOS, Celso Ribeiro. Contencioso administrativo. Revista de Processo, v. 14, p. 187, abr. 1979.

BECKER, Alfredo Augusto Carnaval tributário. São Paulo: Saraiva, 1989.

BETTI, Emilio. Teoría general de las obligaciones. Revista de Derecho Privado, Madrid, 1969.

BIM, Eduardo Fortunato. A inconstitucionalidade da responsabilidade objetiva no Direito Tributário sancionador. Revista dos Tribunais, v. 788, jun. 2001.

BORGES, José Souto Maior. O princípio da segurança na Constituição Federal e na Emenda Constitucional 45/2004. Implicações fiscais. In: PIRES, Adilson Rodrigues; TORRES, Heleno Taveira (Org.). Princípios de direito financeiro e tributário: estudos em homenagem ao profes sor Ricardo Lobo Torres. Rio de Janeiro: Renovar, 2006.

BULLESBACH, Alfred. Princípios de teoria dos sistemas. In: KAUFMANN, A.; HASSEMER, W. Introdução à filosofia do direito e à teoria do direito contemporâneas. Trad. Manuel Seca de Oliveira. Lisboa: Fundação Calouste Gulbenkian, 2002.

CALMES, Sylvia. Du principe de protection de la confiance légitime en droits allemand, 
communautaire et français. Paris: Dalloz, 2001.

CAMPELO, Juliana Endriss C. É possível haver responsabilidade sem culpa no direito tributário? Revista Tributária e de Finanças Públicas, v. 110, maio 2013.

CAMPOS, Marcelo. A utilização do procedimento administrativo tributário como parâmetro de fixação do percentual de multa punitiva. Revista Tributária e de Finanças Públicas, v. 101, nov. 2011, p. 293.

CAMPOS, Miriam de A. Machado e. O princípio da boa-fé objetiva. No prelo.

CANARIS, Claus-Wilhelm. Die Vertrauenshaftung im Deutschen Privatrecht. München: Verlag C. H. Beck, 1971.

CANOTILHO, J. J. Gomes. Direito constitucional e teoria da constituição. Coimbra: Almedina, 2000.

CANTO, Gilberto de Ulhôa. Temas de direito tributário. Rio de Janeiro: Alba, 1964. v. I. Janeiro, 1954.

Trabalhos da Comissão Especial do Código Tributário Nacional. Rio de

CARNEIRO DA FRADA, Manuel Antonio de Castro Portugal. Teoria da confiança e responsabilidade civil. Coimbra: Almedina, 2005.

CARrAZZA, Roque Antonio. Curso de direito constitucional tributário. 20. ed. São Paulo Malheiros, 2004.

CARVALHO, Paulo de Barros. Curso de direito tributário. 21. ed. São Paulo: Saraiva, 2009.

Direito tributário, linguagem e métodos. São Paulo: Noeses, 2008.

. O princípio da segurança jurídica em matéria tributária. In: FÓRUM DE QUESTÕES CONTROVERTIDAS EM MATÉRIA TRIBUTÁRIA. Anais... Belo Horizonte, 2004.

CASAGRANDE, Juarez. Das recentes ilegalidades criadas pela Receita Federal do Brasil em prol de obstaculizar o direito ao crédito presumido instituído pela Lei 9.363/1996: desrespeito ao ato jurídico perfeito e demais garantias constitucionais. Revista dos Tribunais, v. 920, jun. 2012.

CASSONE, Vittorio. Fontes do direito tributário: espécies e efeitos práticos. Revista Tributária e de Finanças Públicas, v. 15, abr. 1996.

CLÉVE, Clémerson Merlin. Crédito-prêmio do IPI. Eventual mudança de orientação jurisprudencial e princípio constitucional da segurança jurídica. Revista dos Tribunais, v. 831, jan. 2005.

COÊLHO, Sacha Calmon Navarro. Curso de direito tributário brasileiro. 10. ed. Rio de 
Janeiro: Forense, 2009.

COÊLHO, Sacha Calmon Navarro. Teoria e prática das multas tributárias. 2. ed. Rio de Janeiro: Forense, 1995.

CORREAA DE SOUZA, Victor Roberto. Os desafios da justiça administrativa brasileira. Revista de Processo, v. 38, n. 218, p. 133-161, abr. 2013.

COUTO E SILVA, Almiro do. O princípio da segurança jurídica (proteção à confiança) no direito público brasileiro e o direito da administração pública de anular se us próprios atos administrativos: o prazo decadencial do art. 54 da lei do processo administrativo da União (Lei no 9.784/99). RPGE, Porto Alegre, v. 27, n. 57, p. 33-75, 2004a.

Princípios da legalidade da administração pública e da segurança jurídica no estado de direito contemporâneo. RPGE, Porto Alegre, v. 27, n. 57, p. 11-31, 2004b.

A responsabilidade pré-negocial no direito administrativo brasileiro. $R D A, \mathrm{n}$. 217, p. 163-171, 1999.

COVIELLO, Pedro José Jorge. La protección de la confianza del administrado. Buenos Aires: Abeledo-Perrot - Lexis, Nexis, 2004.

DE PLÁCIDO E SILVA, Vieira. Vocabulário jurídico. 12. ed. Rio de Janeiro: Forense, 1996. v. I.

DERZI, Misabel Abreu Machado. Modificações da jurisprudência: proteção da confiança, boa-fé objetiva e irretroatividade como limitações constitucionais ao poder judicial de tributar. São Paulo: Noeses, 2009.

DI PIETRO, Maria Sylvia Zanella. Direito administrativo. São Paulo: Atlas, 2010.

DIAS, Karem Jureidini. O ágio no contexto do planejamento fiscal e a posição do tribunal administrativo. Revista Tributária das Américas, v. 5, jan. 2012.

DIDIER JR, Fredie. Comportamento da parte e interpretação da coisa julgada. O caso do Campeonato Brasileiro de 1987. Revista de Processo, v. 211, set. 2012.

DWORKIN, Ronald. Taking rights seriously. 6. tir. London: Duck worth, 1991.

Is a law a system of rules?. In: DWORKIN, R. M. (Ed.). The Philosophy of Law. Oxford: Oxford University Press, 1977.

FAGUNDES, Seabra. O controle dos atos administrativos pelo Poder Judiciário. Rio: Konfino, 1950.

FERRAZ JR., Tércio Sampaio. Irretroatividade e jurisprudência judicial. Manole, 2008.

FRAZÃO, Ana de Oliveira. Breve panorama da jurisprudência brasileira a respeito da boafé objetiva no seu desdobramento da supressio. Revista de Direito Privado, São Paulo, v. 44, 28-57, out. 2010. 
FREITAS, Leonardo E. Silva de Almendra. Revista Tributária e de Finanças Públicas, v. 54, jan. 2004.

FRITZ, Ossenbühl. Die Rücknahme fehlerhafter begünstigender Verwaltungsakte. 2. ed. Berlin: Walter de Gruyter, 1965.

GARCIA LUENGO, Javier. El principio de la proteción de la confianza en el derecho administrativo. Madrid: Civitas, 2002.

GARCÍA MAYNEZ, Eduardo. Filosofía del derecho. 16. ed. Ciudad de México: Porrúa, 2007.

GIANNETTI, Leonardo Varella. Segurança jurídica e coisa julgada: uma análise crítica do Parecer 492/2011 da Procuradoria-Geral da Fazenda Nacional. Revista Tributária e de Finanças Públicas, v. 110, maio 2013.

HEY, Johanna. Steuerplannungssicherheit als Rechtsproblem. Köln: Otto Schmidt, 2002.

KREIBICH, Roland. Der Grundsatz von Treu und Glauben im Steuerrecht. Band 12. Heidelberg: C. F. Muller Verlag, 1992.

KUGLER, Herbert Morgenstern. Da aplicação do princípio da boa-fé objetiva em questões tributárias - teoria e jurisprudência. Revista Tributária e de Finanças Públicas, v. 105, jul. 2012.

LARENZ, Karl. Metodologia da ciência do direito. Trad. José de Sousa Brito e outro. 2. ed. Lisboa: Fundação Calouste Gulbenkian, 1978.

LUHMANN, Niklas. Confianza. Trad. Amada Flores. Santiago: Anthropos Universidad IberoAmericana. 1996.

Mulino, 1978.

Sistema giuridico e dogmatica giuridica. Trad. Alberto Febbrajo. Bologna: Il

MACHADO E CAMPOS, Miriam de A. O princípio da boa-fé objetiva. No prelo.

MACHADO, Brandão. Repetição do indébito no direito tributário. In: (Coord.). Direito tributário - estudos em homenagem ao Prof. Ruy Barbosa Nogueira. São Paulo: Saraiva, 1984. p. 59-106.

MACHADO, Hugo de Brito. Comentários ao código tributário nacional. São Paulo: Atlas, 2004. v. II.

MARQUES, Cláudia Lima. Prescrição das ações coletivas, pretensão dos depositantes em poupança popular e a proteção da confiança do jurisdicionado na alteração da jurisprudência consolidada dos tribunais. Revista de Direito do Consumidor, v. 77, jan. 2011.

MARQUES, José Roberto. Costume. Revista de Direito Privado, v. 22, abr. 2005. 
MARTINS, Ives Gandra da Silva. Da sanção tributária. 2. ed. rev. e atual. São Paulo: Saraiva, 1998.

. Isenção tributária critérios legais permitidos para a interpretação das isenções em face da lei maior e da lei complementar. Revista dos Tribunais, 599/33, set. 1985.

(Org.). Auto de infração objetivando desconsiderar planejamento tributário realizado com pleno respeito às leis tributárias e comerciais, lavrado antes da LC 104/2001 - ilegalidade e inconstitucionalidade do procedimento fiscal. Revista Tributária e de Finanças Públicas, v. 38, maio 2001.

1993.

Cadernos de Pesquisas Tributárias, n. 18. São Paulo: Resenha Tributária,

MARTINS-COSTA, Judith (Org.). A reconstrução do direito privado - reflexo dos princípios, diretrizes e direitos fundamentais constitucionais no direito privado. São Paulo: Revista dos Tribunais, 2002.

MARTINS-COSTA, Judith H. Princípio da confiança legítima e princípio da boa-fé objetiva. Termo de Compromisso de Cessação (TCC) ajustado com o Cade. Critérios de interpretação contratual: os "sistemas de referência extracontratuais" ("circunstâncias do caso") e sua função no quadro semântico da conduta devida. Princípio da unidade ou coerência hermenêutica e "usos do tráfego". Adimplemento contratual. Revista dos Tribunais, v. 852, out. 2006.

MAURER, Hartmut. Direito administrativo geral. Trad. Luís Afonso Heck. Barueri: Manole, 2006.

Elementos do direito administrativo alemão. Trad. Dr. Luís Afonso Heck. Porto Alegre: Sergio Antonio Fabris, 2001.

Allgemeines Verwaltungsrecht. München: C. H. Beck, 1999.

MEIRELLES, Hely Lopes. Direito administrativo brasileiro. São Paulo: Malheiros, 2003.

MENDONÇA, Maria Luiza Vianna Pessoa de. O princípio constitucional da irretroatividade da lei. Belo Horizonte: Del Rey, 1996.

MENEZES CORDEIRO, Antonio Manuel da Rocha e. Da boa-fé no direito civil. Lisboa: Almedina. 3. reimpr. 2007.

Princípio da confiança legítima e princípio da boa-fé objetiva. Termo de Compromisso de Cessação (TCC) ajustado com o Cade. Critérios de interpretação contratual: os "sistemas de referência extracontratuais" ("circunstâncias do caso") e sua função no quadro semântico da conduta devida. Princípio da unidade ou coerência hermenêutica e "usos do tráfego". Adimplemento contratual. Revista dos Tribunais, v. 852, out. 2006.

MICHAEL, Lothar. Der allgemeine Gleichheitssatz als Methodennorm komparativer 
Systeme. Berlin: Duncker und Humblot, 1997.

MORAES, Bernardo Ribeiro de. Costume administrativo (direito tributário). Enciclopédia Saraiva do Direito, São Paulo: Saraiva, 1977.

MUCKEL, Stefan. Kriterien des verfassungsrechtlichen Vertrauensschutzes bei Gesetzesänderungen. Berlin: Duncker und Humblot, 1989.

MUSSOLINI JUNIOR, Luiz Fernando. Revista Tributária e de Finanças Públicas, v. 66, jan. 2006.

NERY JUNIOR, Nelson. Creditamento do IPI - Produtos Isentos e Não Tributados. Revista dos Tribunais. Soluções Práticas, v. 1, set. 2010a.

$2010 \mathrm{~b}$.

Suspensão do processo. Revista dos Tribunais. Soluções Práticas, v. 4, set.

NOGUEIRA, Ruy Barbosa. Coisa julgada e orientação fiscal. Revista dos Tribunais, n. 594/26, abr. 1985.

Imposto de Renda - autuação e lançamento de pessoa jurídica incluindo, antes do término do ano-base, operações cuja renda terá de ser apurada pelo futuro balanço e demonstração da conta de lucros e perdas - o requisito instransponível da consumação do fato gerador para o nascimento da obrigação tributária principal - impostos instantâneos e periódicos. Revista dos Tribunais, 443/104, set. 1972.

Teoria do lançamento tributário. São Paulo: Revista dos Tribunais, 1965.

Aspectos do direito tributário na profissão do contabilista e exame de alguns problemas tributários da atualidade. Revista dos Tribunais, v. 313, n. 50, p. 20-32, nov. 1961.

OLIVEIRA, Ricardo Mariz. Fundamentos do Imposto de Renda. São Paulo: Quartier Latin, 2008.

OLIVEIRA, Ubirajara Mach de. Princípios informadores do sistema de direito privado: a autonomia da vontade e a boa-fé objetiva. Revista de Direito do Consumidor, n. 23-24, São Paulo: RT, p. 56-60, jul./dez. 1997.

OSSENBÜHL, Fritz. Die Rücknahme fehlerhafter begünstigender Verwaltungakte. 2. ed. Berlin: Walter de Gruyter, 1965.

PEIXOTO, Marcelo Magalhães. Conceito de legislação tributária uma análise do art. 96 do CTN. Revista Tribunais e de Finanças Públicas, v. 42, jan. 2002.

PEREIRA, Caio Mário da Silva. Instituições de direito civil. Contratos. 11. ed. atual. por Régis Fichtner: Rio de Janeiro. Forense, 2004. v. III.

PÉREZ LUÑO, Antonio-Enrique. La seguridad jurídica. 2. ed. Barcelona: Ariel, 1994. 
PIRES, Adilson Rodrigues; TORRES, Heleno Taveira (Orgs.). Princípios do direito tributário e financeiro. Rio de Janeiro: Renovar, 2006.

PITTONDO, Maysa de Sá. A interpretação da legislação tributária em interesse do contribuinte um releitura do critério de interpretação in dubio contra fiscum. Revista Tributária e de Finanças Públicas, v. 109, mar. 2013.

POHL, Heiki. Rechtsprechungänderung und Rückanknüpfung. Berlin: Duncker \& Humboldt, p. 173. Tradução não autorizada pelo autor de Kirsten Lage, 2005.

PONTES DE MIRANDA, Francisco Cavalcanti. Comentários à Constituição de 1967, com a Emenda n. 1, de 1969. 2. ed. São Paulo: Revista dos Tribunais, 1974. t. V.

PÜTTNER, Günter. Vertrauensschutz im Verwaltungsrecht. VVDStRL, Berlin/New York: Walter de Gruyter, Heft 32, 1974.

REALE, Miguel. Revogação e anulamento do ato administrativo. Rio de Janeiro: Forense, 1968.

RECURSO EM Mandado de Segurança no $13.807 /$ GB. 3 ${ }^{\text {a }}$ Turma, Relator Ministro Prado Kelly. Revista Trimestral de Jurisprudência, v. n. 37, p. 248-251, 1966.

RECURSO EXTRAORDINÁRIO no 78.533/SP. 2 2 a Turma, Relator Ministro Décio Miranda. Revista Trimestral de Jurisprudência, n⿳ำ 100, p. 1.086/1.091, jun. 1982.

REVISTA DE DIREITO ADMINISTRATIVO, Rio de Janeiro, 52/246.

RIBEIRO, Ricardo Lodi. A segurança jurídica do contribuinte: legalidade, não-surpresa e proteção à confiança legítima. Rio de Janeiro: Lumen Juris, 2008.

RUBINSTEIN, Flávio. Boa-fé objetiva no direito financeiro e no direito tributário brasileiros. Dissertação (Mestrado) - Faculdade de Direito da Universidade de São Paulo, São Paulo, 2008.

SABBAG, Eduardo. Manual de direito tributário. São Paulo: Saraiva, 2009.

SCHONBERG, Soren. Legitimate expectations in administrative law. Oxford: Oxford University Press, 2000.

SCHOUERI, Luís Eduardo. Direito tributário. São Paulo: Saraiva, 2011.

SEIXAS FILHO, Aurélio Pitanga. controle administrativo da legalidade do lançamento tributário e a coisa julgada administrativa em matéria fiscal. Revista dos Tribunais e de Finanças Públicas, v. 61, mar. 2005.

SIMONE, Diego Caldas Rives de. Segurança jurídica e tributação: da certeza do direito à proteção da confiança legítima do contribuinte. Dissertação (Mestrado) - Pontifícia Universidade Católica de São Paulo, São Paulo, 2009. 
SOARES, Leonardo Oliveira. Ainda o princípio da confiança nos pronunciamentos jurisdicionais. Revista de Processo, v. 218, abr. 2013.

O princípio da confiança nos atos estatais como fonte mediata de direitos processuais no estado democrático de direito brasileiro - análise a partir de caso concreto. Revista de Processo, São Paulo, v. 206, p. 323-334, maio 2012.

SOMBRA, Thiago Luís Santos. A tutela da confiança em face dos comportamentos contraditórios. Revista de Direito Privado, v. 33, jan. 2008.

SOUSA, Rubens Gomes de. Estudos de direito tributário. São Paulo: Saraiva, 1950.

TEODOROVICZ, Jeferson. O panorama histórico da legalidade tributária na doutrina tributária. Revista Tributária e de Finanças Públicas, v. 100, set. 2011.

TIPKE, Klaus; LANG, Joachim. Direito tributário (Steuerrecht). Trad. do alemão por Luiz Dória Furquim. 18. ed. Porto Alegre: Sérgio Antonio Fabris, 2008. v. 1.

TORRES, Heleno Taveira. Direito constitucional tributário e segurança jurídica: metódica da segurança jurídica do sistema constitucional tributário. 2. ed. São Paulo: Revista dos Tribunais, 2012.

TORRES, Júnio. Penalidades fiscais e consolidação anual da legislação tributária. Revista de Tribunais, 506/15, dez. 1977.

TORRES, Ricardo Lobo. Limitações ao poder impositivo e segurança jurídica. In: MARTINS, Ives Gandra da Silva (Org.). Limitações ao poder impositivo e segurança jurídica. São Paulo: RT/CEU, 2007.

Renovar, 2005.

Tratado de direito constitucional financeiro e tributário. Rio de Janeiro:

A interpretação do direito tributário pela Administração. Separata da ABDF Resenha - 2. trim. Rio de Janeiro, 1996.

TRABALHOS DA Comissão Especial do Código Tributário Nacional. Rio de Janeiro: IBGE, 1954.

TREVIJANO, Pedro José Gonzalez. La costumbre en derecho constitucional. Madrid: Publicaciones delCongreso de los Diputados, 1989.

VILCHEZ, Jorge Pando. El silencio administrativo en el procedimiento tributario. In: ABAD YUPANQUI, Samuel B. et al. (Org.). Temas de derecho tributário y de derecho publico: libro homenaje a Armando Zolezzi Möller. Lima: Palestra, 2006. p. 667-668.

WOLFF, Hans J.; BASCHOFF, Otto; STOBER, Rolf. Verwaltungsrecht. München: C. H. Beck, 1994. v. 1.

ZAVASCKI, Teori Albino. Eficácia das sentenças na jurisdição constitucional. São Paulo: Revista dos Tribunais, 2001. 
ZIMMERMAN, Reinhard; WHITTAKER, Simon. Goodfaith in European Contract Law. New York: Cambridge University Press, 2008.

\section{Sites}

http://dados.pgfn.fazenda.gov.br/dataset/pareceres/resource/4922011

http://www2.unafisco.org.br/noticias/boletins/2007/junho/anexo_2370_analise.pdf 